Portland State University

PDXScholar

$1-1-2010$

\title{
Internal Displacement in Colombia: Violence, Resettlement, and Resistance
}

Juan Esteban Zea

Portland State University

Follow this and additional works at: https://pdxscholar.library.pdx.edu/open_access_etds Let us know how access to this document benefits you.

\section{Recommended Citation}

Zea, Juan Esteban, "Internal Displacement in Colombia: Violence, Resettlement, and Resistance" (2010). Dissertations and Theses. Paper 359.

https://doi.org/10.15760/etd.359

This Thesis is brought to you for free and open access. It has been accepted for inclusion in Dissertations and Theses by an authorized administrator of PDXScholar. Please contact us if we can make this document more accessible: pdxscholar@pdx.edu. 
Internal Displacement in Colombia: Violence, Resettlement, and Resistance

\section{by}

Juan Esteban Zea

A thesis submitted in partial fulfillment of the requirements of the degree of

\section{Master of Arts \\ in \\ Anthropology}

Thesis Committee:

Michele R. Gamburd, Chair

Sharon A. Carstens

José Padín

\section{Portland State University}

(C) 2010 


\section{$\underline{\text { Abstract }}$}

The majority of the estimated four million internally displaced persons (IDPs) in Colombia who have fled from their lands and homes have migrated to urban centers. This study, performed in Bogotá, Colombia between April and September 2009, examines how IDPs cope with living in a new, urban environment after violent displacement. I held interviews with IDPs, the non-displaced public, and government workers; performed participant-observation in government offices and neighborhoods; and examined archival material. The work examines cultural anthropological topics of violence, migration, and resistance. A discussion of state and structural violence reveals the current hardships many rural Colombians face. Analysis shows that symbolic violence manifests itself through 'othering' narratives and practices, which affect how IDPs resettle in Bogotá. The research demonstrates how IDPs' practices challenge state bureaucracy and government workers and refute the non-displaced public's stereotypes. IDPs agency both reproduces and transforms social structures in the city of Bogotá. I discuss how collective IDP agency leads to actions of resistance through public marches and takeovers. This research contributes to the field of anthropology by highlighting relations between power structures and individuals, examining how IDPs experience and resist symbolic violence, and demonstrating how IDPs create new identities in situations of forced migration. 


\section{Acknowledgements}

I want to first thank all of the participants in this study. Every person whom I interviewed provided valuable information to make this thesis possible. I will forever be grateful to the displaced persons who shared their violent and traumatic life stories with me. I am privileged to have received their trust and to have been able to record their personal narratives.

I also would like to thank Dr. Michele R. Gamburd for all her advice, suggestions, support, help, and patience with me in the last three years, especially in the writing process of this work. Thank you also to Dr. Sharon A. Carstens and Dr. José Padín for all the critical feedback and suggestions in this academic enterprise.

Thank you to my family for all of your love, care, and support in all of my endeavors. You have all been there for me at every step. Deb Healey provided wonderful editing advice during the writing process despite being busy with work. Deb: thank you. Thank you also to Colin Morse, Meris Mullaley, and Emily Shepard for editing feedback. I want to also thank everyone in the Anthropology Department at Portland State University for all of your support in the last three years.

Finally, I want to thank Dr. Andrés Salcedo Fidalgo, Johanne Alvarez Palacios, and all of the workers at FAMIG who were supportive of this research while I was in Colombia. 


\section{Table of Contents}

Abstract $\quad$ i

Acknowledgements

List of Figures $\quad$ v

Acronyms

Chapter 1-Introduction 1

Displacement and Violence $\quad 3$

Research Site $\quad 4$

Contemporary Situation of Displacement $\quad 7$

Research Methodology and Design 10

Thesis Overview 15

Chapter 2-Colombia: Land, History, and the Context for

Displacement 20

Geography 20

History $\quad 32$

Law $\quad 37$

Lived Reality $\quad 39$

Conclusion $\quad 45$

Chapter 3-Violence: Explaining the Experiences of IDPs Before,

During, and After Forced Displacement 47

Overview 48

The Internal Armed Conflict: State and

Insurgent Violence 50

Economic and Development Strategies:

Structural Violence $\quad 57$

The Formation of the IDP Other: Symbolic Violence 62

Conclusion 69

Chapter 4-Internally Displaced Persons' Identity Formations 71

Identification and Categorization: 'Othering' and

State Identity Formations 76

Self-Understanding and Social Location: IDP

Responses to 'Othering' in New Social Contexts 82

Commonality, Connectedness, and Groupness: Group

Identity and Identity Politics 87

Conclusion 
Chapter 5-Social Conditions: Resistance and Acceptance 93 Agency and Structures $\quad 94$

Individual Agency: Reproductions and Transformations 99

Effects of Power on IDPs' Schemas and Resources 102

Events and Collective Agency: Marches 103

Events and Collective Agency: Takeovers 107

Conclusion 110

$\begin{array}{lr}\text { Chapter 6-Conclusion } & 113\end{array}$

Narratives of Violence $\quad 115$

Interacting with Bureaucracies and the Non-Displaced Public 116

IDP Agency $\quad 117$

Future Research: Continuing Difficulties 118

$\begin{array}{lr}\text { References } & 123\end{array}$

Appendices $\quad 133$

Appendix A-Bogotá's Strata by Monthly Wages 133

Appendix B-Bogotá's Strata through Geographical Distribution 134

Appendix C-Questions Asked During Interviews $\quad 135$

Appendix D-Letter IDPs Receive After Declaration 137 


\section{List of Figures}

Figure 1.1. Map of Bogotá, Colombia

Figure 1.2. View of Bogotá from Monserrate Church looking southwest

Figure 1.3. The Monserrate and Guadalupe Mountains 6

Figure 1.4. Ciudad Bolivar-Usme UAO Office 13

Figure 2.1. Shaded Relief Map of Colombia 21

Figure 2.2. The Andean Region of Colombia 23

Figure 2.3. The three Cordilleras of Colombia 24

Figure 2.4. The Caribbean Region of Colombia 26

Figure 2.5. The Pacific Region of Colombia 28

Figure 2.6. The Llanos Orientales of Colombia 29

Figure 2.7. The Amazon Region of Colombia 30

Figure 2.8. Steps that displaced people must follow in order to receive state aid 43

Figure 5.1. March in the streets of the locality Usme during during Week of the Migrant, September 13-21, 2009 
Acronyms

CODHES Consultaría para los Derechos Humanos y el Desplazamiento (Consultancy for Human Rights and Displacement)

ELN Ejército de Liberación Nacional (National Liberation Army)

EPL Ejército Popular de Liberación (Popular Liberation Army)

FAMIG Fundación de Atención al Migrante (Foundation for Attention to the Migrant)

FARC Fuerzas Armadas Revolucionarias de Colombia (Revolutionary Armed Forces of Colombia)

ICA International Coffee Agreement

IDMC Internal Displacement Monitoring Centre

IDP Internally Displaced Person

IHL International Humanitarian Law

ISI Import-Substitution Industrialization

NGO Non-Governmental Organization

SAP Structural Adjustment Program

UAO Unidad de Atención y Orientación para la población en situación de desplazamiento

UNHCR United Nations High Commission on Refugees 


\section{Chapter 1-Introduction}

It is a shame that in Colombia there continue to be citizens obliged to flee in the face of constant aggression from armed groups at the margins of the law and, in many cases, from State personnel who, through action, omission, incapability, or complicity, cannot guarantee the fundamental right to life, honor, and property of all citizens, as the National Constitution orders ${ }^{1}$ (CODHES 2010:1).

The day I met Bernardo, he came up to a window stall at the Ciudad BolivarUsme UAO government office seeking an emergency fund of 150,000 Colombian pesos (around US \$75.00). He walked on two crutches and placed them gently to his right as he signed obligatory paperwork. From where I was sitting, I only concluded that the man must have had an injury. Later, after I finished speaking with a government worker, I realized that Bernardo had no left leg. I wanted to ask him about the amputation, but he was in the middle of something important. Later while sitting in a waiting area, I saw that Bernardo was still waiting for his emergency fund. I approached him, and as we talked about his reason for being at the UAO office, Bernardo agreed to do an in-depth interview with me.

Bernardo was displaced from the north of the department of Cundinamarca. ${ }^{2}$ Bernardo shared with me the way in which he was recruited and taken forcibly by the FARC (Fuerzas Armadas Revolucionarias de Colombia, the Armed Revolutionary

\footnotetext{
1 "Es lamentable que todavía en Colombia haya civiles obligados a huir ante la agresión constante de grupos armadas al margen de la ley y, en muchos casos, de agentes de Estado que por acción, omisión, incapacidad o complicidad no garantizan el derecho fundamental a la vida, honra y bienes de todos los ciudadanos, como ordena la Constitución Nacional" (text translated by author).

${ }^{2}$ A department (or departamento in Colombia) is an administrative political subdivision. In Colombia, in terms of size and regional administrative power, a department is between a US state and county. Colombia is made up of 32 departments, each having a capital city. Bogotá is both the Colombian capital and the departmental capital of Cundinamarca. Similarly, Medellín is the departmental capital of Antioquia. Departments within Colombia make up geographic, cultural, and economic regions.
} 
Forces of Colombia) when he was only 19. For fourteen months, Bernardo ran errands between camps, then moved to an infantry position fighting in the frontlines against the military and paramilitary, and finally became a demining expert. While doing that job, Bernardo lost his leg. One day leading a march, Bernardo stepped on a mine that he did not see, a mine that the FARC had planted. He remembers after that a long stint at a jungle hospital, followed by a two month trek to get him to the nearest town.

Bernardo shared stories of his 14-month stint with the guerrillas. He concluded that all parties involved in the armed conflict spew propaganda attempting to destroy the other. "They are all the same," Bernardo said, referring to the Colombian military, paramilitaries, and guerrillas. Each armed actor had a stake and each lied and tried to indoctrinate people they recruited.

Bernardo's wife abandoned him and their daughters after he came back, saying that she was scared of what could happen to them with the constant threats from the military. Bernardo was beginning the process of understanding the steps necessary to receive funding from government workers. He had had his own plot of land in the north of Cundinamarca where for the last couple of years he and his two daughters had worked the land. Bernardo enjoyed cultivating crops on his land, and had been doing so without his leg. Bernardo worked the land, hobbling around on a crutch. $\mathrm{He}$ recounted how miserable it was, but in the end, the land provided plenty of crops. But constant threats from all sides made him leave his home. The guerrillas would come every other month to his home, demanding the service he still owed the FARC. 
Because of Bernardo's missing leg, the guerrillas insisted that either his elder daughter or youngest brother take his place. Military and police would periodically arrest him for interrogation or beat him in his home. Forced recruitment and violence from different armed actors in Colombia displaced Bernardo and forced him to resettle in Bogotá. Today, Bernardo relies on the help of his new neighbors and kind strangers to live in the city.

\section{Displacement and Violence}

Bernardo's story resonates with many that internally displaced persons (IDPs) shared with me in Colombia in 2009. Forced recruitment of youth and young adults into guerrilla forces, the armed conflict, violent threats, hostilities, and murders of family or friends by armed actors are the principal reasons Colombia has experienced such large numbers of IDPs since the mid-1980s. This research shows how violence has affected people and their families. It also shows how people attempt to make a new life socially and economically in urban centers.

Violence affects people in different ways. This research examines how IDPs experiencing the violence of Colombia have reacted. In urban centers of Colombia we see political agency through practices that alter the IDP subject (Feldman 1991). IDPs' interactions with government workers, IDP takeovers of public spaces and state offices, and visible marches organized by IDPs through streets all show how political agents reproduce and contest state discourses of security and development.

This study looks at post- (forced) migration from home and land of origin. I examine how people resettle in Bogotá. This study is limited in that individuals who 
decided not to migrate to cities after experiencing violence were not included in the study group (see Lubkemann 2008).

\section{$\underline{\text { Research Site }}$}

The urban center of Bogotá (Figure 1.1 and 1.2) is industrial and hectic. Bogotá is the center of the economy, production, and trade and is the social and political capital of Colombia. Heavy pollution, uncontrollable traffic, and large numbers of people participating in the informal economy also characterize Bogotá. Like in all other cities in Colombia, in Bogotá, neighborhoods are divided by socioeconomic strata (Appendix A and B) that separate citizens based on both wealth and (unofficially) ethnic background. The city has an estimated population of over 8.2 million people. The city has 20 localities or districts, each having numerous

neighborhoods. The north and northeast areas of the city, for example the locality of Usaquén, house the wealthier residents. The localities Ciudad Bolivar and Usme, situated in the south of Bogotá, house residents found in lower socioeconomic strata. Such places also house significant numbers of displaced people.

Near the geographical center of Colombia, Bogotá is located in the highlands of the Eastern Cordilleras (Cordillera Oriental). The city's altitude, 2,640 meters (8,661 feet) above sea level, and the tropical location create varying temperature averages throughout the year. The city's average temperature is $14^{\circ} \mathrm{C}\left(57^{\circ} \mathrm{F}\right)$ and fluctuates yearly between $3^{\circ}$ and $25^{\circ} \mathrm{C}\left(37^{\circ}\right.$ to $\left.77^{\circ} \mathrm{F}\right)$. The month of January has both the coldest and hottest average temperatures of the year. The city's street layout has a 


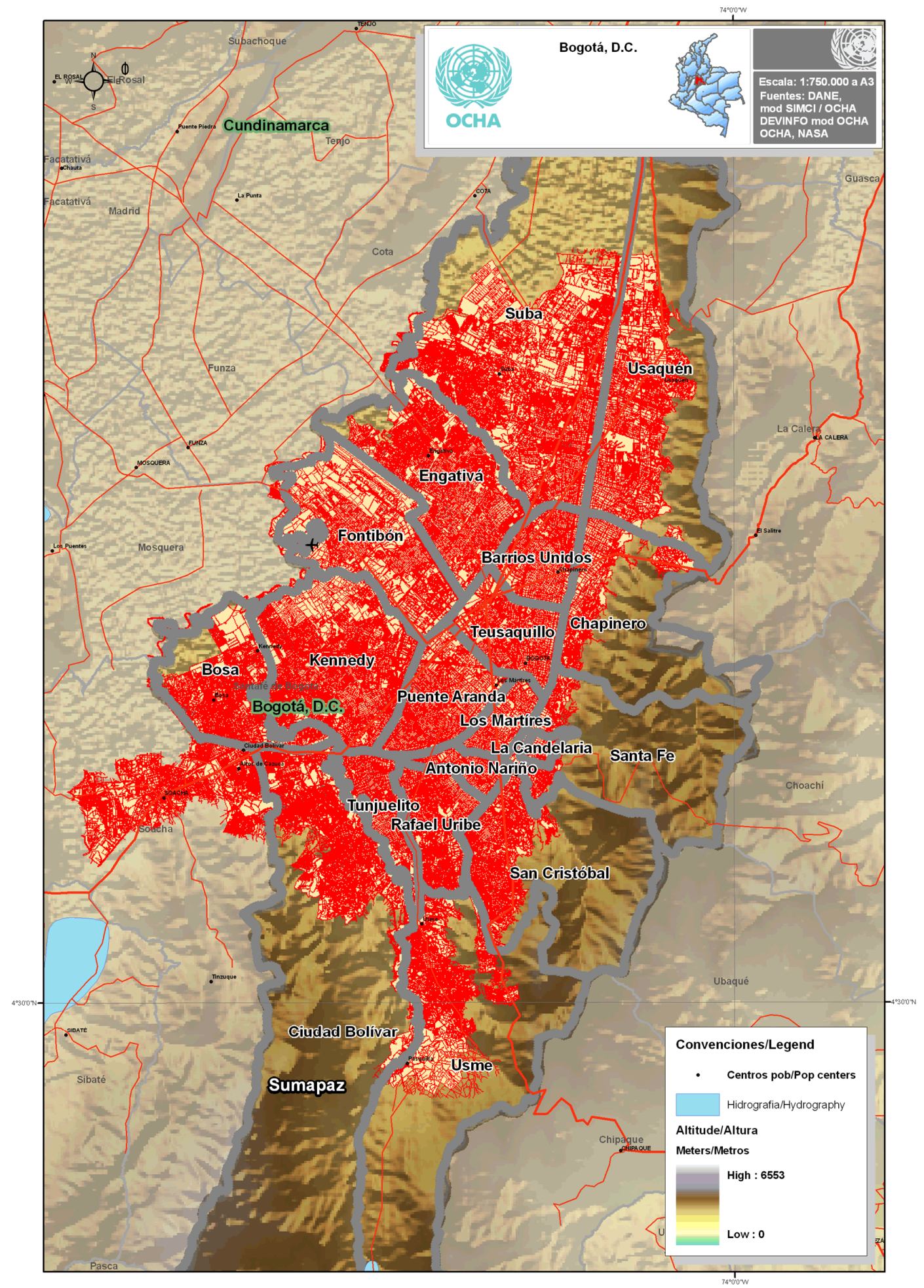

Figure 1.1. Map of Bogotá, Colombia. The map also demarcates the city's localities. (Source: http://www.colombiassh.org/site/IMG/png/Bogota_A3.png). 


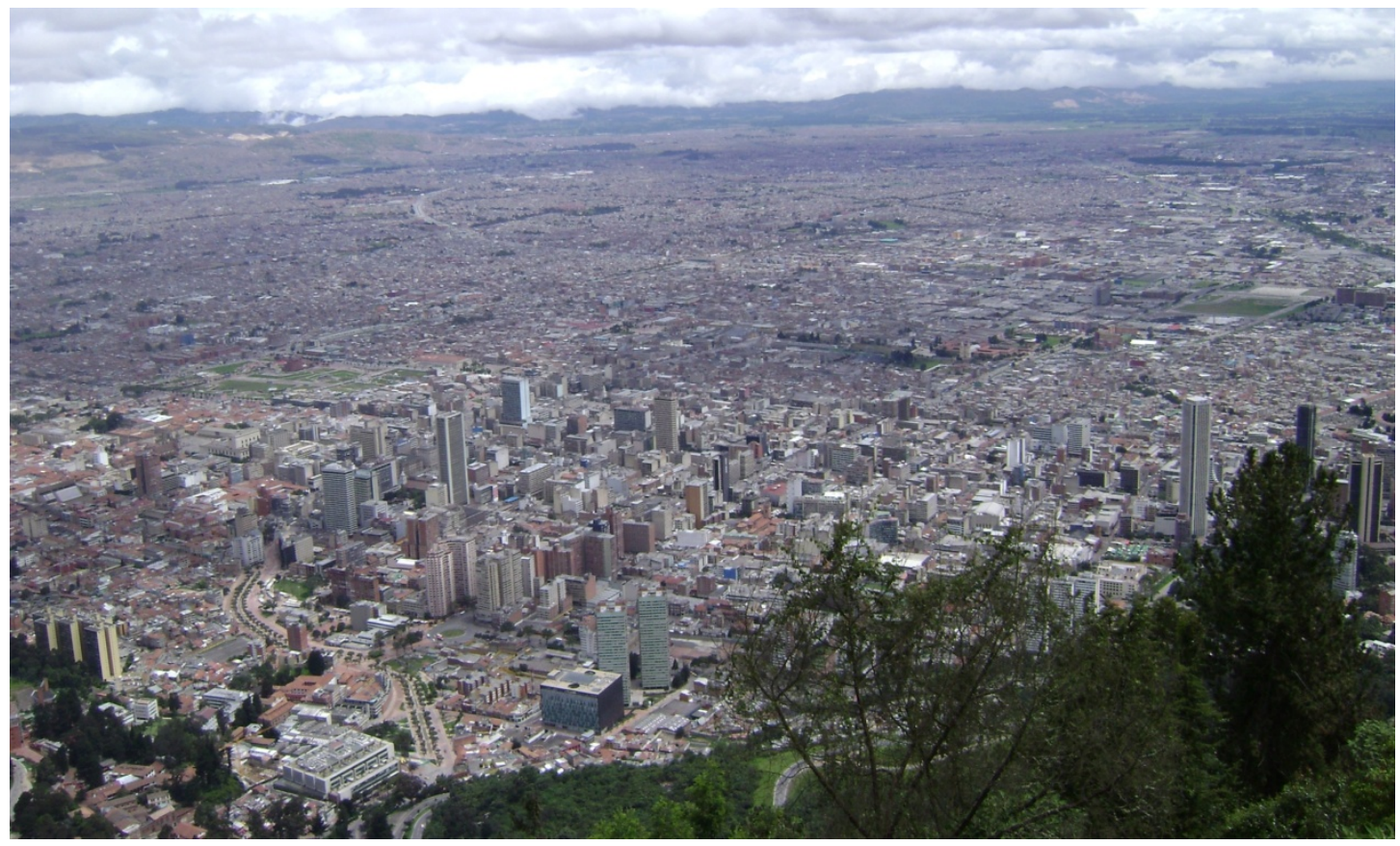

Figure 1.2. View of Bogotá from the Monserrate Church looking southwest. (Photograph by Juan Esteban Zea).

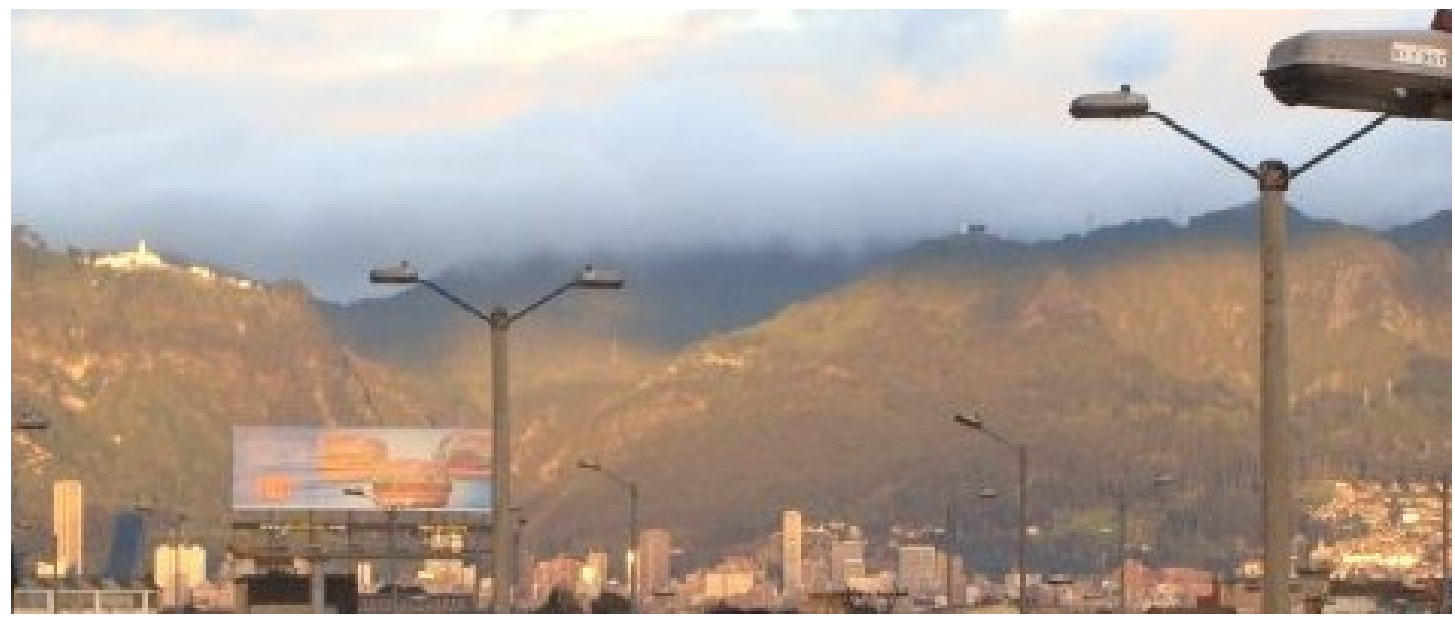

Figure 1.3. The Monserrate and Guadalupe Mountains. Downtown Bogotá can be seen in the picture, with no development on the mountain side. (Photograph by Juan Esteban Zea). 
design like other Spanish colonial cities, with streets coming out of the main city square (Plaza Bolivar). Carreras (avenues) run parallel to the Monserrate and Guadalupe Mountains that act as a barrier to city development to the east (Figure 1.3), while calles (streets) run perpendicular to carreras.

Bogotá has the highest numbers of internally displaced persons (IDPs) of any other city in the country. In 2009, around 43,000 IDPs arrived in Bogotá (CODHES 2010:1). The non-governmental agency CODHES (Consultoría para los Derechos Humanos y el Desplazamiento, Consultancy for Human Rights and Displacement) also states that the IDP population of Bogotá makes up around 3-5\% of the total population of the city-300,000 to 400,000 people.

\section{Contemporary Situation of Internal Displacement}

Colombia has a population of over 45 million people, making it the fourth most populous country in the Americas behind the United States, Brazil, and Mexico. The country currently has one of the world's longest and largest armed conflicts raging in its territory (Meltzer and Rojas 2005; Avilés 2006a). Colombia is the only country in the region with a growing number of IDPs. Every major Colombian city receives thousands of individuals fleeing from violence every year. The Colombian government has registered 3,303,979 people as internally displaced, while CODHES places the IDP population within Colombia at 4,915,579 (IDMC 2010). CODHES (2010:1) estimates that violence displaced over 286,000 people from their homes in 2009, a reduction from 2008, when over 380,000 were displaced. Displaced persons come from all segments of the population, including landed elites and poor peasants, 
and from all political parties. Despite this, certain populations are overrepresented. Afro-Colombians and indigenous populations only make up four and two percent of the entire population respectively. However, both groups make up significant percentages of displaced individuals, with Afro-Colombians constituting $33 \%$ and Indigenous populations 5\% (Bello 2006).

After suffering displacement due to violence, large numbers of IDPs migrate to Bogotá and attempt to make a new life and home, economically and socially. In this project on displaced populations, government agencies, neighborhoods, and the unaffected public, I found that IDPs chose to settle in Bogotá for numerous reasons. Some IDPs interviewed chose to come to Colombia's capital because of already established connections, social support systems, or family and friend networks. Salcedo Fidalgo (2006) similarly concludes in his research that social networks aid IDPs forced out of their land or homes to establish new lives in Bogotá.

In my interviews, IDPs also stated that Bogotá's national reputation-as the wealthiest city, full of job opportunities, home to the politicians, and the backyard of Colombia's movie stars-convinced them that they would find plenty of opportunities to escape the violence, create a new life in which they could support their families, and resolve their situation easily and rapidly. Publications written by the city government suggest that Bogotá will welcome displaced individuals happily: the city offers "alternatives for generating their social inclusion within the capital...so that, the displaced may start and strengthen their process of socioeconomic stabilization, reconstruct their rights as citizens, and began future actions;" the city's goal is also to 
"sensitize residents of Bogotá to the presence of displaced citizens" (Proyecto Misión Bogotá 2001:6). IDPs arriving in Bogotá undertake a range of political actions that have caused significant changes in Colombian law concerning IDPs in the last fifteen years.

Another major motive for migrating to Bogotá is a desire to blend into city life. Interviews illustrate the feeling of many IDPs that in the Colombian capital they will be able to escape the violence they lived through. I argue that this new anonymity, however, does not ameliorate people's displaced situation. Rather, IDP anonymity exists because a new form of violence-the symbolic violence of social marginalization and economic exclusion—is created (Rojas Rodriguez 2001:28).

Displacement has been studied from numerous angles. In the situation of Colombia, social scientists have looked at the numerous reasons and factors that cause violent displacement (Ahumada Beltrán et al. 2004; Bello A. 2006; CODHES 2010; Garay 2009; and many others). Authors have discussed the relation between economic policies and displacement (Avilés 2006b), personal decision of fleeing (Engel and Ibáñez 2007), social networks (Salcedo 2005), and the effects on gender in the countryside (Merteens 2007). This research seeks to fill a gap in the literature on what happens to displaced individuals after they arrive in urban centers. In specific, I focus on interactions between IDPs and the bureaucratic agencies that serve them. I also examine social movements that were active in the city of Bogotá during 2009. 


\section{Research Methodology and Design}

Between April and September of 2009, I conducted fieldwork in the city of Bogotá, spending a month during that period in the city of Medellín. I performed participant-observation, structured, semi-structured, informal, and open-ended interviews, and archival research. ${ }^{3}$ I relied on snowball sampling (Bernard 2006) to meet new informants and people willing to be interviewed. When possible, I gathered life histories of residents who have experienced displacement. I collected and analyzed archival material. At universities, libraries, and government offices in both Bogotá and Medellín, I gathered historical texts and policies relating to how displaced individuals have been treated in Colombia. This information provided context for contemporary issues and current policies that IDPs face.

During my fieldwork I conducted 120 interviews (See Appendix C for a detailed list of interview questions). Interviews were held with displaced persons arriving in Bogotá from all over Colombia, government workers at UAOs (La Unidad de Atención y Orientación para la población desplazada, Agency of Attention and Orientation for the displaced population), NGO workers who helped IDPs, and individuals in the non-displaced public. Interviews with IDPs took place in various locations and for various durations. I met IDP interviewees at UAO offices or at FAMIG (Fundación de Atención al Migrante, Foundation for Attention for Migrants).

\footnotetext{
${ }^{3}$ All names referencing IDPs in this study are pseudonyms to safeguard identities. No real names are used when referring to internally displaced persons. In addition, personal traits are hidden as best as possible. When referencing places of origin, I mention department rather than city or town in order to protect personal information. I conducted this research with the review and approval of the Human Subjects Research Review Committee (HSRRC) at Portland State University.
} 
These interviews ranged from 20 minutes to three hours in length. All the interviews were held at a place chosen by the interviewee. Places included peoples' homes, restaurants/cafes, offices, and waiting areas. IDP interviews consisted of structured, informal, and focus group discussions and numbered just over seventy of the total interviews. Some interviews were recorded, but I noticed a definite difference in people's level of comfort when interviews were recorded. People who were being recorded were very aware of the digital recorder and worried about whether their voice was being taped. After about a month, I decided that taking notes during interviews was a better strategy. I wrote down the majority of the information from interviews in rough notes that I expanded and typed as soon as I was able to.

Interviews with government workers and NGO workers usually lasted over an hour. These talks occurred at the workers' desk or office or at another location of the workers' choice if the interviews occurred during lunch hour. I interviewed 22 government and NGO workers. The interviews with the non-displaced public numbered just under thirty and I held them at locations where people chose, either their homes or businesses. I held 4 focus group interviews with the non-displaced public. People invited to participate were recruited from acquaintances, friends, and people I met throughout the city of Bogotá.

In Bogotá, my work focused on the interactions between IDPs and state workers. An UAO is a government agency found in cities throughout Colombia. At the UAO office of the Bosa-Kennedy communities in Bogotá, I did a pilot project in June and July of 2008 and helped create rapport for my six-month fieldwork in 2009. 
There, I worked with Andrés Quiroga, coordinator of the office. I also conducted fieldwork at the Ciudad Bolivar-Usme UAO (Figure 1.4) office thanks to Carlos Padilla, the state functionary responsible for handing out emergency funds. These offices are in the poorer sectors of town, where the IDP population is concentrated. At the UAO offices, I performed participant-observation during working hours. I visited the offices three to five times a week, for four to six hours during each visit. I learned the bureaucratic steps that displaced people take toward receiving aid. I was present during the interactions between state personnel and displaced persons. Interactions included: IDPs standing in line and asking security personnel to be let in; government workers lecturing IDPs at waiting areas; IDPs asking for emergency funds; IDPs going through the displacement declaration process; and IDPs speaking with one another regarding displacement, living in the city, and discrimination experienced living in Bogotá.

I held interviews with UAO staff to understand their perception of the displaced population. These interviews focused on how government workers see the displaced population; how the city is helping this vulnerable population; and how they think the situation might be improved. In addition, I conducted informal interviews with IDP clients to understand how they navigate the bureaucracy of agencies created to help them.

In addition to my fieldwork at the UAO offices, I conducted interviews with displaced people at FAMIG, a non-governmental, Catholic organization. At this 


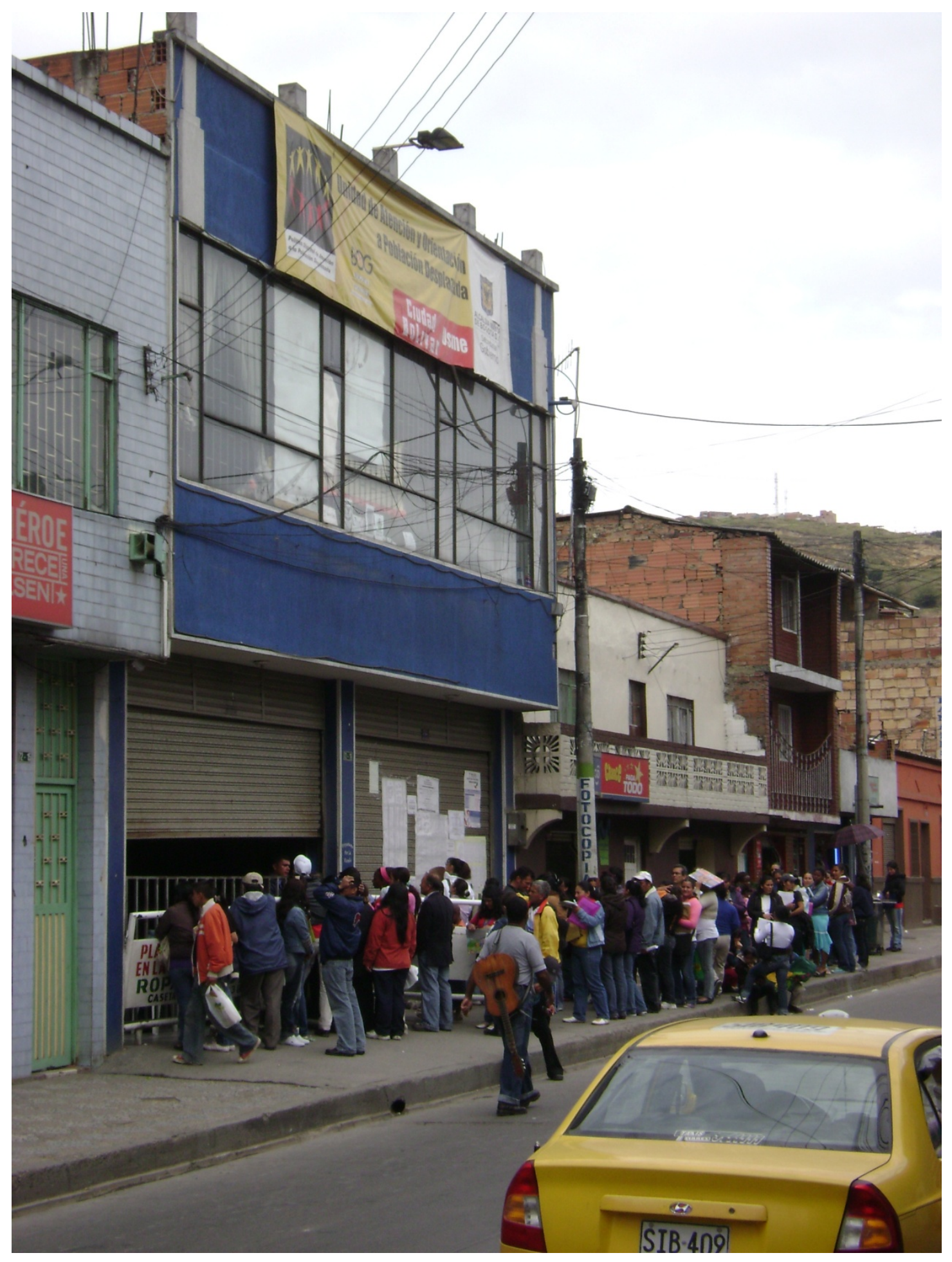

Figure 1.4. Ciudad Bolivar-Usme UAO Office. (Photograph by Juan Esteban Zea). 
location, and at CODHES, I also interviewed staff who worked to improve the lives of IDPs resettling in Bogotá.

In Medellín, arriving in July and leaving in the middle of August 2009, I visited neighborhoods in the newly constructed housing project in the northern section of the municipality, Los Pajaritos. The city government of Medellín specifically constructed these housing projects for the displaced population and indigent people of the city. During my pilot study in 2008, I met Danilo, who took me on a walk of his neighborhood and introduced me to neighbors who had experienced displacement. In 2009, I returned to the neighborhood and held interviews. I also visited Medellín offices that help displaced individuals and conducted interviews with city officials.

I was born in Medellín, Colombia, speak fluent Spanish, and I am intimately familiar with life and customs in Colombia. I moved to the United States when I was eight-years old. I have visited the country several times since moving to the United States. In addition, I have family and friends who still reside in Colombia. These connections were instrumental in making contacts for this research. Through this research, I wish to shed light into some of the problems occurring in the country, and, hopefully, begin to formulate concrete solutions for the woes people face.

My interest in studying public policy, the state, and violence-especially in Colombia-developed from different points. As an undergraduate, I partook in an NSF-REU (National Science Foundation-Research Experience for Undergraduates) research project in Nepopualco, Morelos, Mexico. In this research, I completed an independent project centered on law and violence, comparing state policy to the 
practices and customs (usos y costumbres) of Nepopualco. Using this knowledge about law and policy, my undergraduate thesis discussed the history of violence in Colombia since 1810 .

\section{Thesis Overview}

For the research I had four overarching question. My first question was: What do IDPs' narratives demonstrate about different sorts of violence in Colombia? IDPs experience and react to violence differently, and in this research I demonstrate how IDPs live through state, structural, and symbolic violence. The focus of this work is on the symbolic violence that many displaced individuals experience as discrimination and marginalization. Narratives and ethnographic accounts show how symbolic violence is taking place. I also examine the ways in which IDPs respond to the symbolic violence that greets them after resettlement.

My second question asks: How do displaced individuals interact with bureaucracies? Once IDPs resettle in cities such as Bogotá, I examined the ways in which displaced persons interact with government agencies that have been created to help in the resettlement process. I look at how IDPs interact with government agencies at UAO offices. Of particular interest is the gap between official policies and officials' practices; despite progressive laws that have been written to help IDPs, government offices and workers still create roadblocks for accessing critical state funds needed by IDPs.

The third overarching question for this study was: How do IDPs form identity in the face of discrimination and see themselves in relation to the city of Bogotá? 
Displacement profoundly unsettles identity, particularly if an IDP loses a cherished occupation and falls out of contact with valued social networks. Narrative analysis reveals that IDPs bolster identities rooted in their places of origin and contrast that positive self-portrayal to negative 'othering' discourses employed by the nondisplaced public.

My last question guiding the study was: How do IDPs exercise agency in marginal settings within an urban center? IDPs react to symbolic violence in a myriad of ways. Sometimes, IDPs acquiesce to and reproduce existing structures of discrimination at UAO offices so they may more easily access state funds. In contrast, at other times IDPs form social movements that help to transform social institutions. These movements occur in the shape of marches and takeovers of government offices and public spaces.

These four related questions about IDP experiences in Bogotá are situated squarely within an emerging area of anthropological analysis-the study of public policy and the state. Internal displacement has become a prevalent dilemma in several parts of the world. This research presents information on how IDPs have created new lives in urban centers. The analysis examines how IDPs resettling in Bogotá demonstrate culturally-specific agency to enact positive change in their new lives.

Following this introduction, the second chapter of this thesis provides background and context for the study of displacement. I begin with a brief look at the geography of Colombia. I do this in order to describe the varied regions in which many IDPs lived before coming to urban centers. The diverse resources found 
throughout Colombia have become important objects of contestation. I also present a historical view of events occurring in Colombia since the 1930s. The political, social, and violent events of the past have important connections to contemporary IDP problems. This chapter also describes legislative decisions passed by the Colombian Constitutional Court and the Colombian Congress regarding the treatment of IDPs. When followed, these new laws have helped IDP populations in Colombia create positive and significant political voice to create change. The chapter concludes by describing the socioeconomic structures IDPs navigate in Bogotá, structures characterized by large-scale inequality and disproportionate distribution of power.

In chapter three, I discuss different forms of violence occurring in Colombia today. The study of violence provides contributions to the discipline of anthropology. Violence in everyday life, or as actions in response to other actions, demonstrates one way people form structure in their everyday lives (Schröeder and Schmidt 2001:1). This thesis reveals one way people react to violence and how they structure their everyday lives afterward. Though many forms of violence exist, I discuss three types of violence prevalent in IDP descriptions: state, structural, and symbolic violence. State violence is violence carried out or supported by governments. In Colombia, a push for development and the acquisition of new resources have caused state sponsored violence against populations inhabiting resource-rich areas. Counterinsurgency tactics also contribute to this type of violence in Colombia. Structural violence, in the form of large scale inequality, forms hindrances that prevent people from meeting basic needs. Social institutions exclude certain people while others are 
welcome. Symbolic violence is a cultural form of control based on discrimination (Bourdieu 1994). This sort of violence occurs when one person misrecognizes the 'other,' and does not allow that 'other' to have equal rights. Symbolic violence, in the form of racism, classism, and discrimination against IDPs, happens to many individuals in Colombia.

Chapter four examines IDP identity in Bogotá. It shows how IDPs cope with living in a new, urban environment and illustrates how IDPs' new identities form through interactions with the non-displaced public and government functionaries. Within Bogotá we see cultural construction of identity by the state, its functionaries, and the non-displaced public on the one hand, and by IDP identity politics on the other. Actors across Bogotá utilize politics of representation to categorize IDPs and to characterize what they deserve. Dominant discourses within the state and the nondisplaced public demarcate displaced people as homeless, unemployed individuals and unworthy of social services. In contrast, IDPs construct social solidarity, forming positive identities that represent their lives before displacement. 'Othering' narratives and practices manifest themselves in the form of symbolic violence. Collective IDP agency, through actions of resistance, reaffirms IDP identity and challenges 'othering' narratives, leading to political action. I show how IDPs' practices challenge state bureaucracy and government workers and the non-displaced public in a new urban setting.

In chapter five, I discuss the agency of IDPs living in Bogotá. IDPs' agency illustrates both acceptance of and resistance to the structures of power and inequality 
that shape IDP life after resettlement. The chapter presents approaches that IDPs utilize (individual and collective) to change government conduct and to preserve structures that distribute state aid. The discussion focuses on agency, resistance, and acceptance in a framework of practice theory. Internally displaced people continue to use culturally specific projects and goals to achieve social and political change so that IDPs themselves may be able to integrate more easily into the urban center of Bogotá. Change has come in the formulation of new laws, state admissions of wrongdoings and maltreatment, and provision of adequate housing, healthcare, and education.

I turn now to the discussion of geographic, political, and social background for understanding internal displacement in Colombia. 


\section{Chapter 2-Colombia: Land, History, and the Context for Displacement}

If you want to see ruins and pre-Columbian cultures, go to Mexico or Peru; if you want to see the Amazon, go to Brazil; if you want to see beautiful beaches, go to Costa Rica or Puerto Rico; if you want to see the Andes, go to Chile; if you want to see large plains, visit Argentina; if you want to see the Caribbean, go to Cuba or the Dominican Republic; if you want to see the Pacific Ocean, go to Peru; if you want to see deserts, go to Bolivia; but if you want to see everything in one country, go to Colombia ${ }^{4}$ (Colombian saying).

In this chapter, I will draw out several key themes relating to land issues and political-ideological battles, and tie these themes to the current context of displacement. This chapter provides a contextual setting for the experiences of IDPs that shape their overall socioeconomic integration into Colombian cities. A discussion of Colombia's geography will illuminate the areas from which internally displaced persons (IDPs) originate, as well as the rich resources the numerous armed actors fight over. The lack of agrarian reform and security in regions where high numbers of IDPs originate has allowed different actors to battle for these lands, and their resources, over time. Forced displacement in Colombia today originates from a long list of historical factors.

Geography

Located in the northwest corner of South America, Colombia borders Venezuela to the east, Brazil to the southeast, Peru to the south, Ecuador to the southwest, and Panama to the northwest (see Figure 2.1). Colombia is the only

\footnotetext{
4 "Si quiere conocer ruinas y culturas precolombinas, vaya a México o Perú; si quiere conocer la selva amazónica, vaya al Brasil; si quiere conocer playas hermosas, vaya a Costa Rica o Puerto Rico; si quiere conocer los Andes, vaya a Chile; si quiere conocer llanos, vaya a Argentina; si quiere conocer el Caribe, vaya a Cuba; si quiere conocer el Pacifico, vaya a Perú; si quiere conocer desierto, vaya a Bolivia; y si quiere conocer todo eso en un país, vaya a Colombia" (text translated by author).
} 


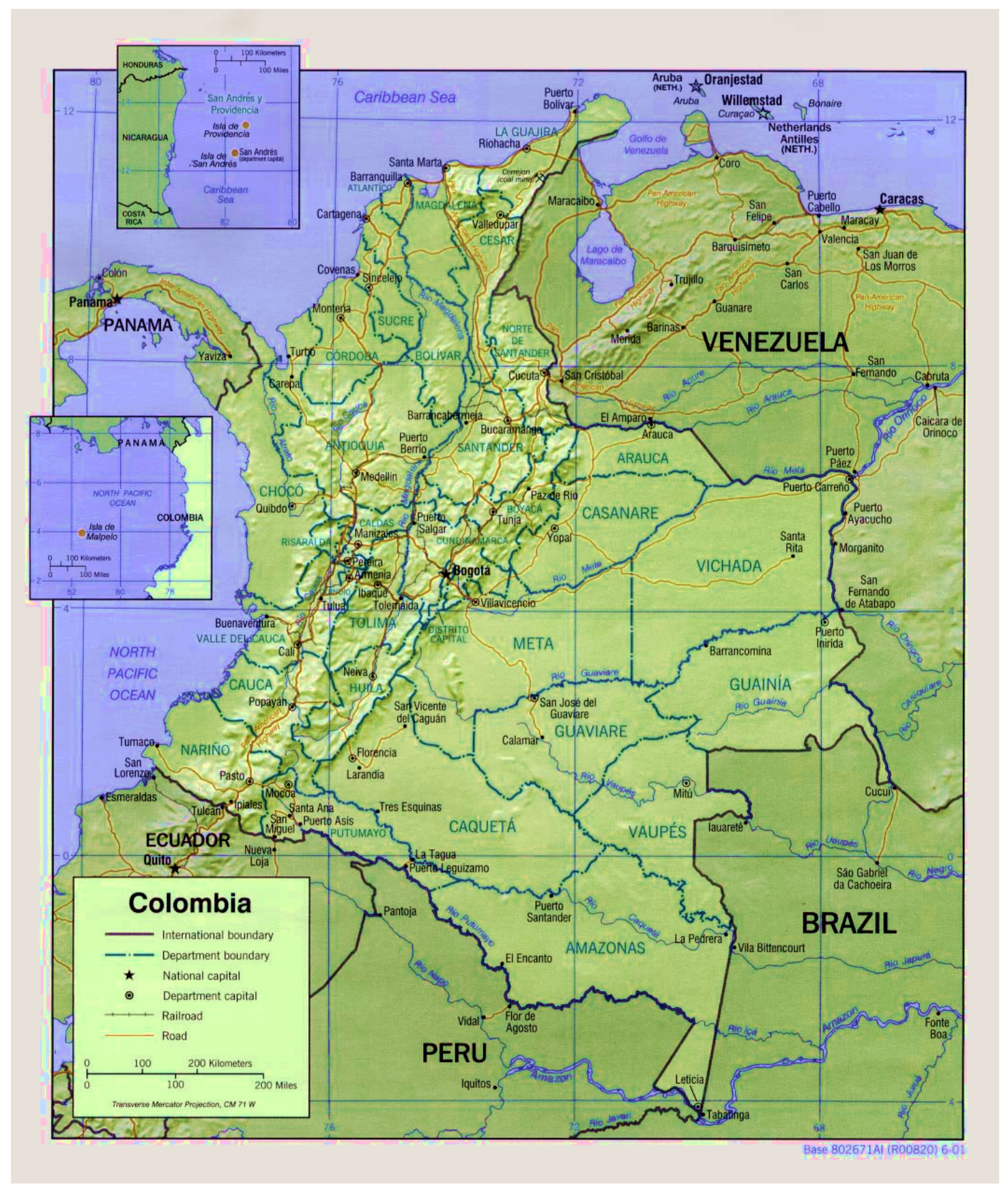

Figure 2.1. Shaded relief map of Colombia, with the 32 departments outlined. (Public Domain Image) 
country in South America that has coastlines on both the Pacific Ocean and the Caribbean Sea. It is the twenty-sixth largest country in the world, having a total of 1,138,914 square kilometers (Central Intelligence Agency 2009). Colombia’s cultures are a mix of indigenous cultures before Spanish colonialism, slaves brought from Africa, and European settlers. The country has the world's second highest biodiversity overall and the world's greatest biodiversity per square meter. As the quote above says, due to Colombia's geographic variability, the country has many diverse and endemic species and as such has been classified as a mega-diverse country (Erret et al 2006:371).

Five main geographical regions characterize the country physically and culturally. The first of these regions is the Andean Region (Figure 2.2), which runs from the south of the country at the border with Ecuador to the north, almost reaching the Caribbean Sea. The Andean mountain range forms three cordilleras (mountain ranges) (Figure 2.3) that stretch north and south through the middle of the country. These cordilleras are the Cordillera Oriental (Eastern Cordillera), Cordillera Central (Central Cordillera), and the Cordillera Occidental (Western Cordillera). The Andean region contains the majority of Colombia's urban cities (of 50,000 inhabitants or more)—Cali and Popayán are on the Cordillera Occidental; the cities of Medellín, Manizales, and Pereira are on the Cordillera Central; and the cities of Bogotá, Tunja, and Bucaramanga are on the Cordillera Oriental. Because of the drastic changes in elevation between the three cordilleras, people divide the land into three 


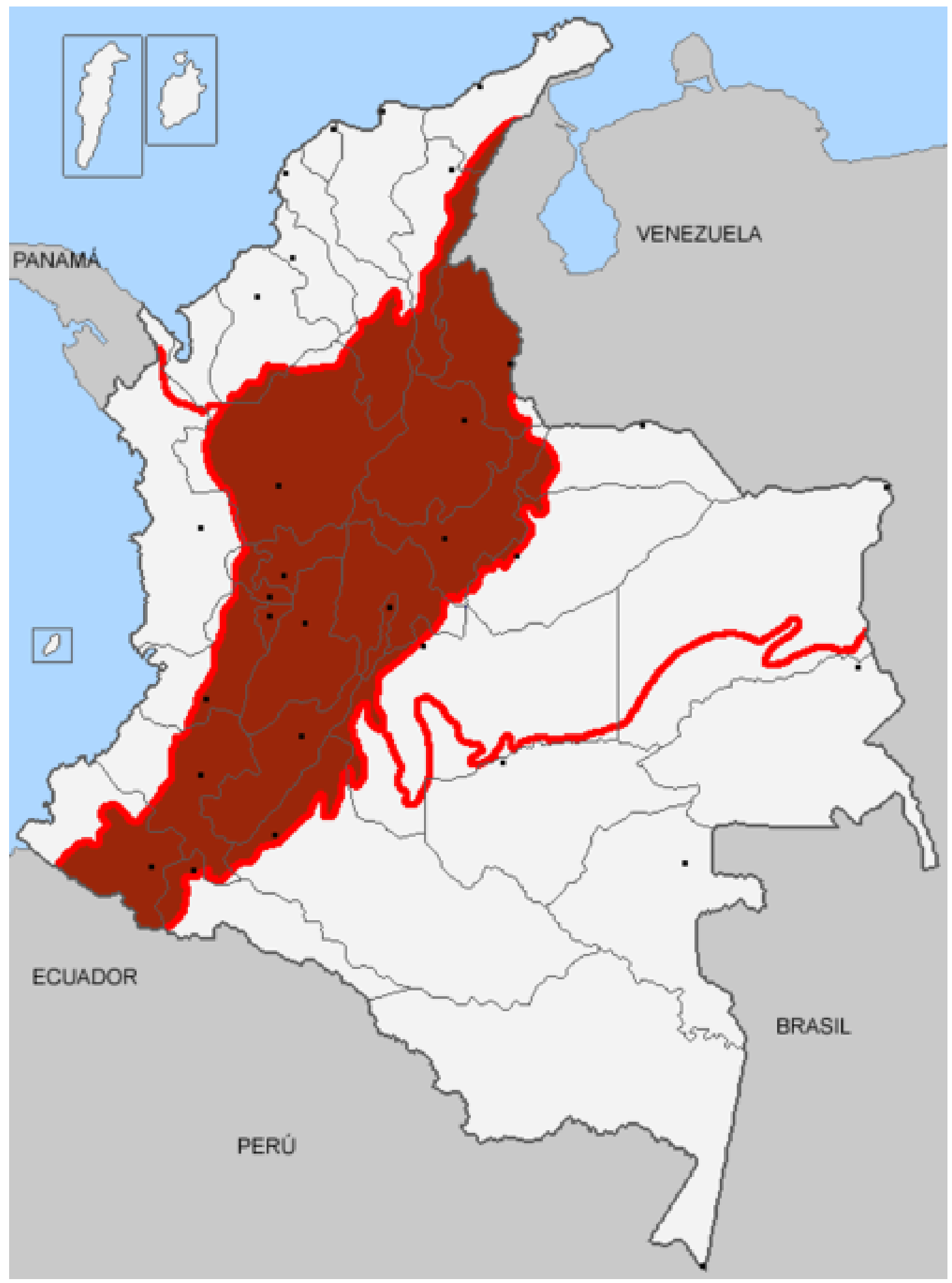

Figure 2.2. The Andean Region of Colombia. (Public Domain Image) 


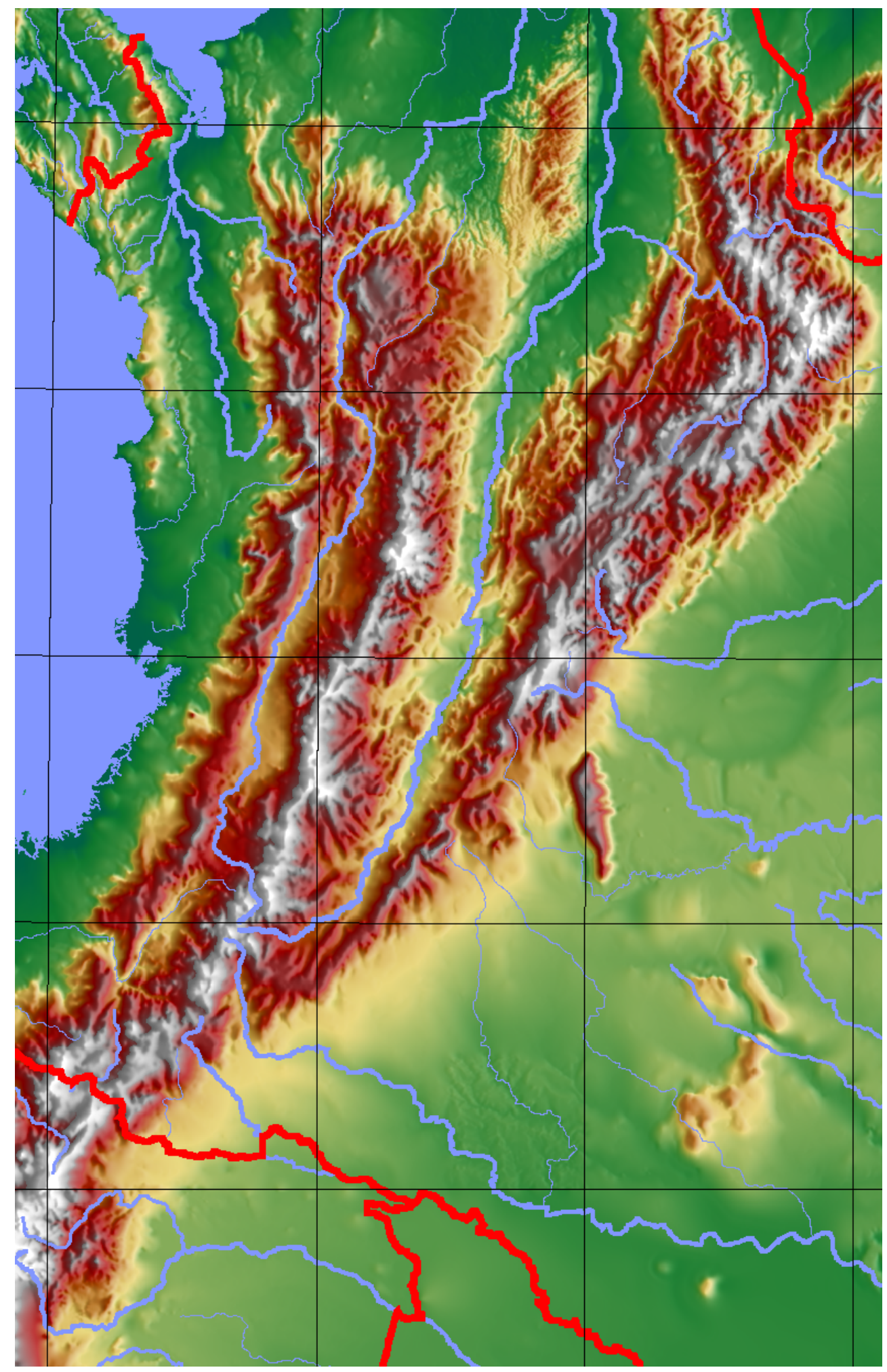

Figure 2.3. The three Cordilleras of Colombia. (Public Domain Image). 
classifications: tierra fría (cold land), tierra caliente (hot land), and tierra templada (temperate land). Cities above 2000 meters above sea level, like Bogotá, are in tierra fría. Melgar, $98 \mathrm{~km}$ southwest of Bogotá, is in tierra caliente. Cities in tierra caliente are below 1000 meters above sea level. At 1500 meters above sea level, Medellín is in tierra templada, land located between 1000 and 2000 meters above sea level. Weather and temperatures vary between the three ranges of altitudes. The three cordilleras also form massive and important river valleys that connect municipalities to each other. People use rivers to transport important goods and supplies to and from the Andean region and the Caribbean region. Culturally, the Andean region is urban and characterized by commerce and industry. Most of the population is mestizo, with a large percentage of the population having European ancestry. Each city has its own accent and regional dishes.

The Caribbean Region (Figure 2.4) is another of the five regions. The region has three main port cities—Cartagena, Barranquilla, and Santa Marta—where most imports come into the country. Colombia's Caribbean coastline goes from the border with Panama in the west to the Guajira desert bordering Venezuela. Along with the Guajira desert, the region also has snow capped peaks and plains that reach south to the Andes region. Culturally, the Caribbean Region is diverse. During colonization, the region's port cities received large influxes of slave populations from Africa. Today, many descendants continue to live in the region. In addition, numerous indigenous populations live in the northern section of the Caribbean region. Large chiefdoms existed prior to the Spanish Conquest. Many indigenous communities 


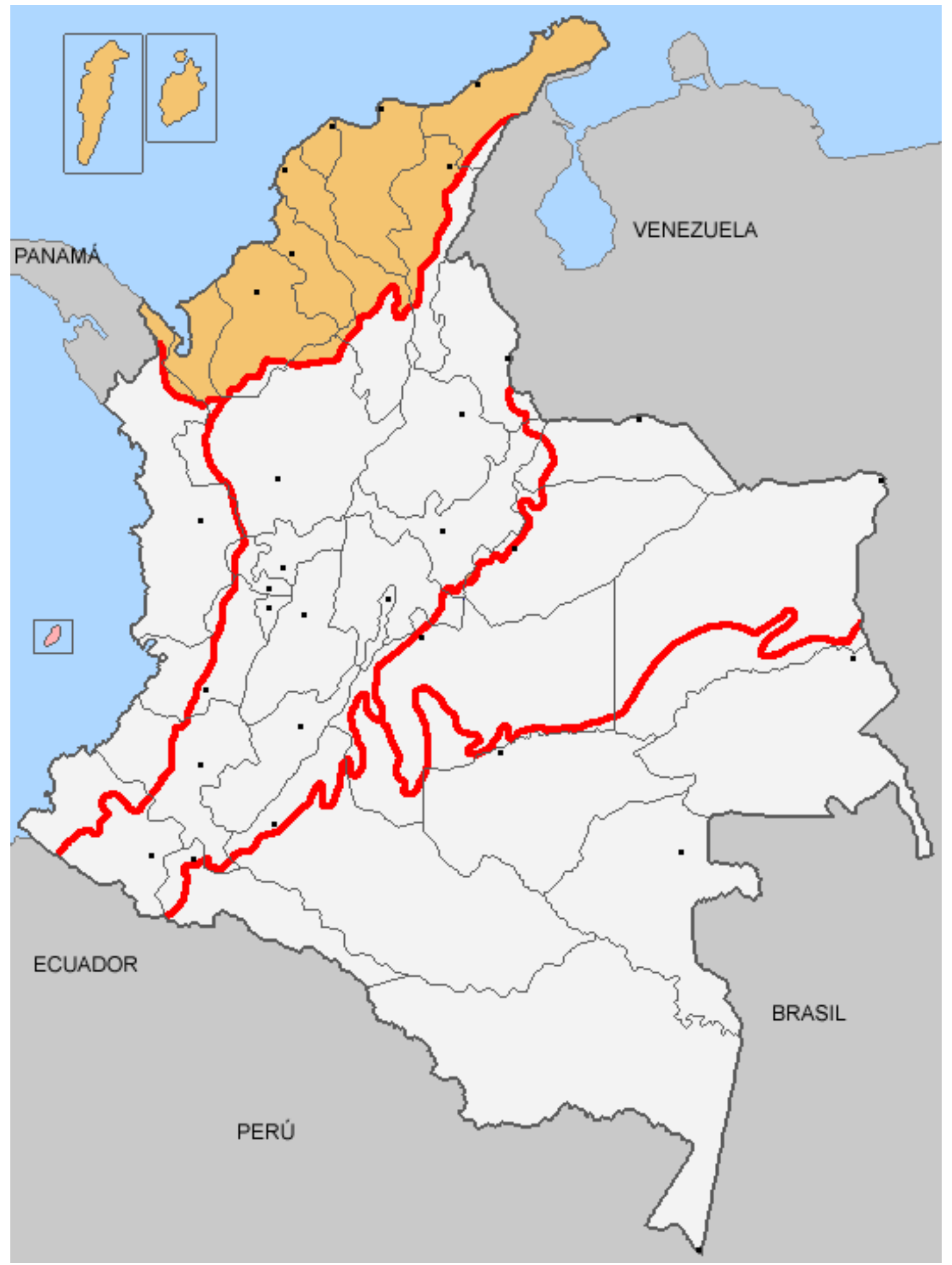

Figure 2.4. The Caribbean Region of Colombia (Public Domain Image.) 
fought against the contemporary state for recognition, which they received in the 1991 Colombia Constitution through the country's adoption of cultural pluralism. Despite the recognitions of cultural pluralism, minority ethnic groups face discrimination.

The Pacific Region (Figure 2.5) stretches from the border of Panama south to the border with Ecuador along the Pacific Ocean coastline. The region is extremely undeveloped due to the diversity of geographical features such as swamps, highlands that reach up to the Cordillera Occidental, and ocean coastline within a narrow land area.

A large flat land area covering almost a quarter of the country, the Llanos Orientales (Eastern Plains) region (Figure 2.6) stretches from the foothills of the Cordillera Oriental to the border with Venezuela in the eastern part of the country. The cattle industry and large oil reserves, which have caused many prospectors to visit the Llanos, characterize the area. Armed guerrillas control large sections of this sparsely populated area—particularly near the border with Venezuela.

The last region is the Amazon Region (Figure 2.7), which covers $41 \%$ of the territory in Colombia (Erret et al 2006:371). The Amazon Region is located in the south of Colombia bordering Peru and Brazil. Many of Colombia's rivers originating in the Cordillera Oriental flow into the Amazon basin. The region is highly undeveloped, and the government has set aside 6,955,751 hectares of protected rain forest and jungle, more than half of the total protected land in the country (Parques Nacionales Naturales de Colombia). 


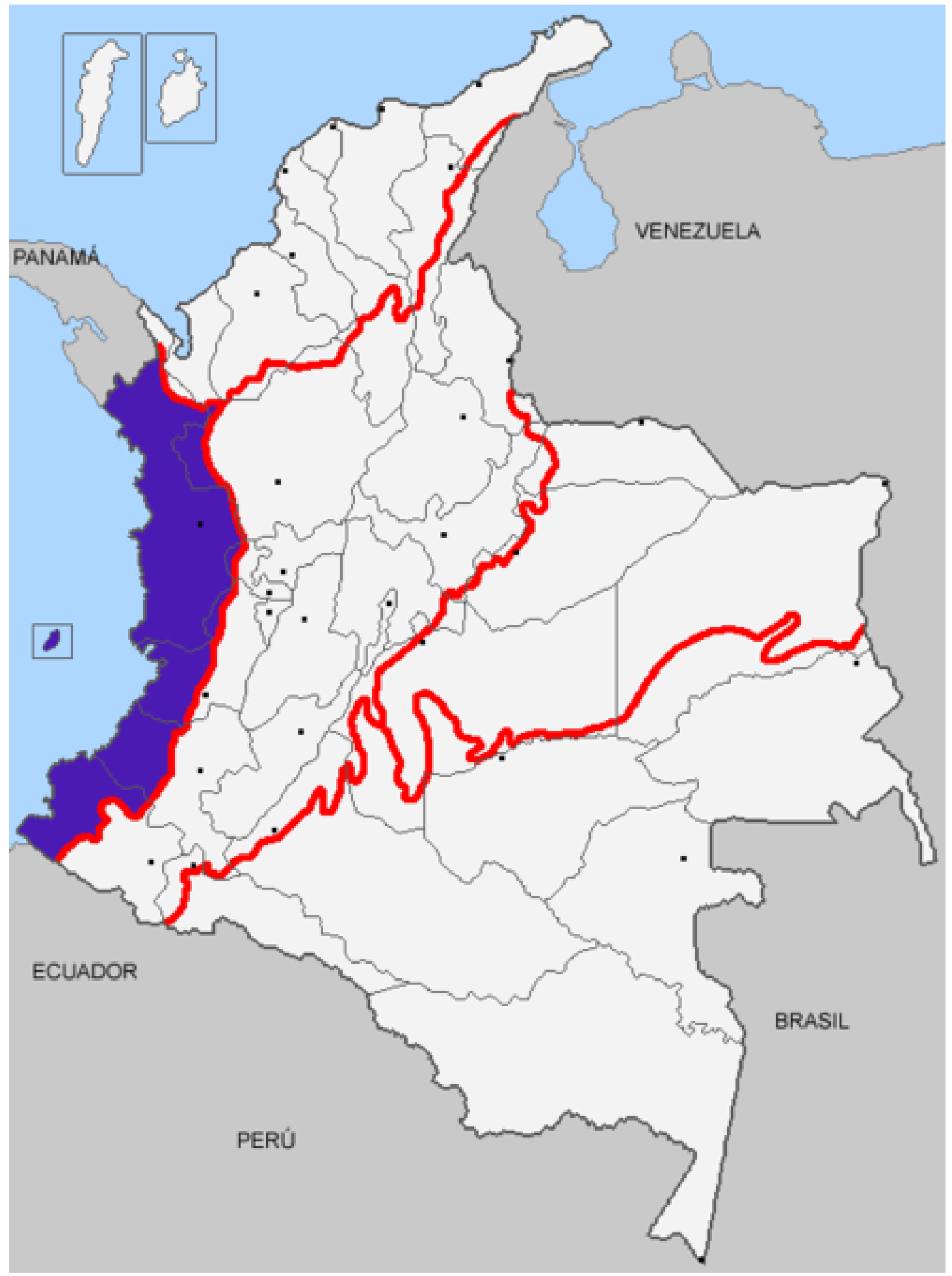

Figure 2.5. The Pacific Region of Colombia. (Public Domain Image.) 


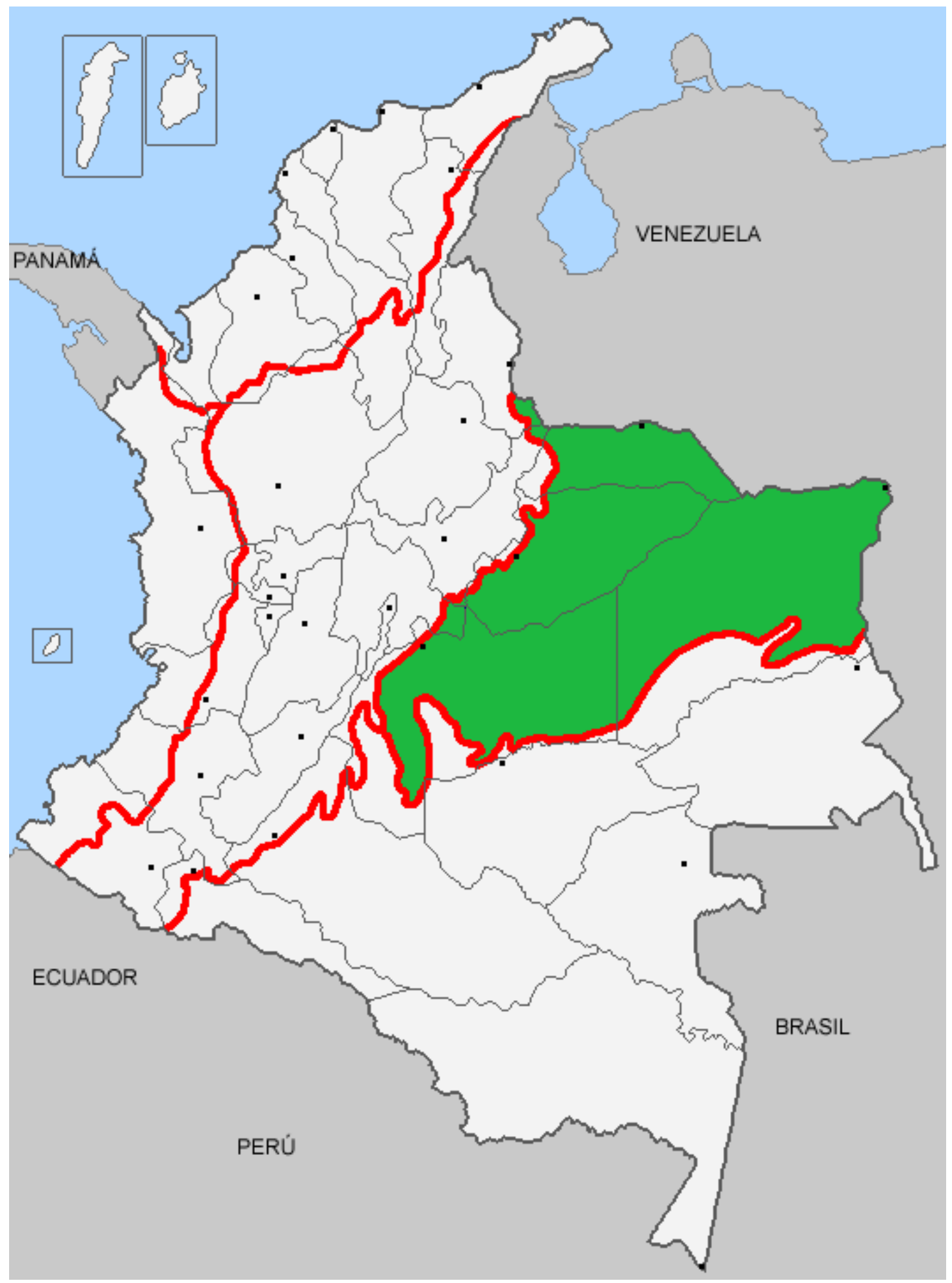

Figure 2.6. The Llanos Orientales Region of Colombia. (Public Domain Image). 


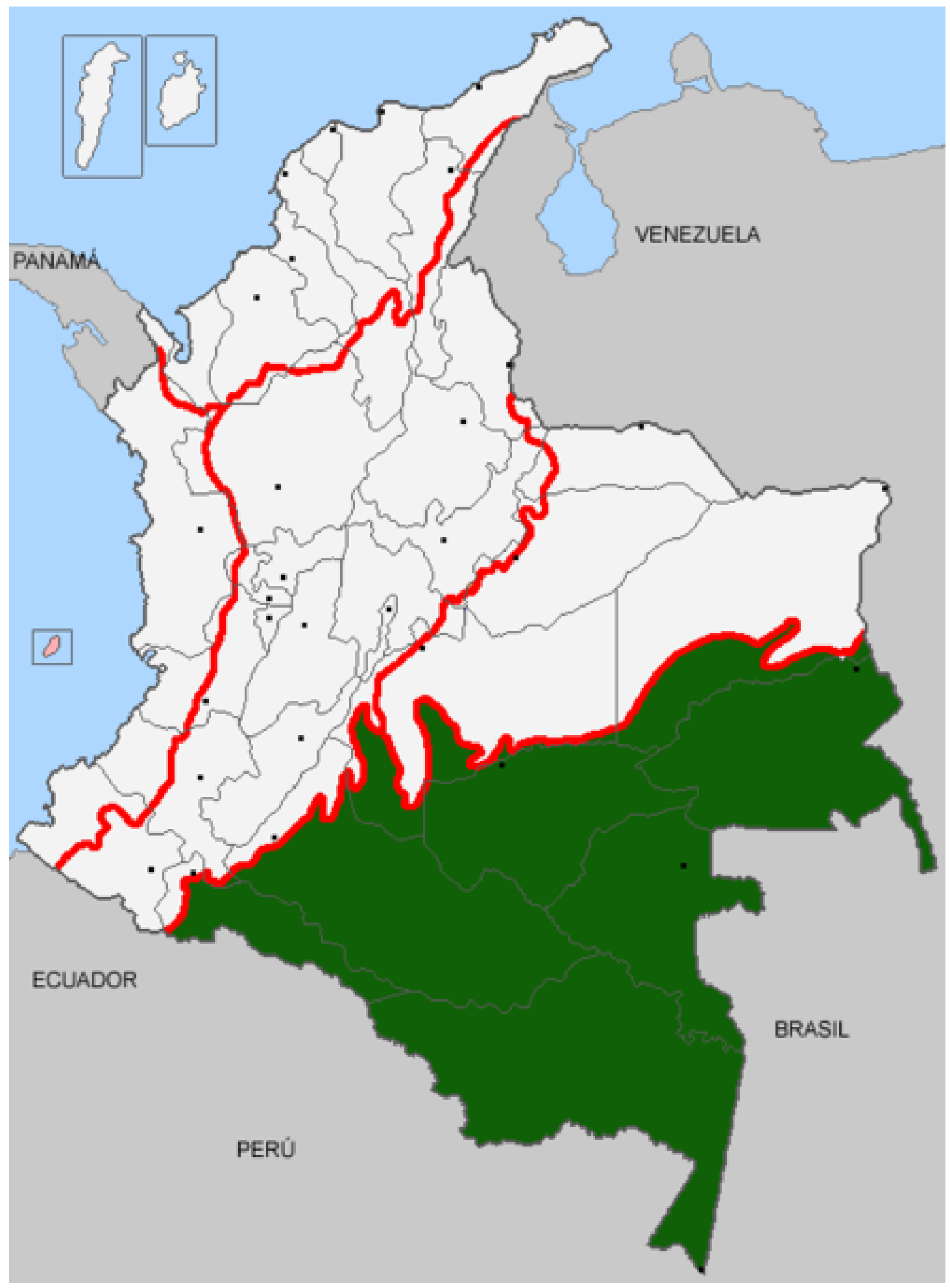

Figure 2.7. The Amazon Region of Colombia. (Public Domain Image). 
Cities in Colombia are home to most of the citizens and are the main recipients of IDPs in the country. Rural areas, though sparsely populated, are where the majority of the displaced originate from. In addition, the IDP population has lost six million hectares of land; $25 \%$ (one and a half million hectares) of which constitutes the overall cultivated land of the country (Garay 2009). IDPs from rural areas become displaced because they live on sought-after land. For example, the department of Bolivar, located in the Caribbean region, was formerly home to large numbers people who became displaced. Here, paramilitary forces have been clearing whole towns, where many of the citizens are Afro-Colombians, for transnational corporations, such as Drummond Mining (Gibbs and Leech 2009). For example, Javier Francisco, a former resident of this department, told me that in his town, five-hundred people who did not leave the town were tortured and killed by paramilitary forces. Transnational corporations have also exploited the Guajira Desert for its natural resources. Coal mining has been responsible for a large percentage of displacement in this area (Webber 2008; Gibbs and Leech 2009). In the Llanos region, the armed conflict has intensified in the department of Arauca. Avilés (2006b) argues that the war against insurgency—carried out by paramilitary forces aided by the government—has escalated in Arauca because the government desires to safeguard petroleum deposits and pipelines from guerrilla attacks. The land and resources are beneficial for transnational corporations' investments. The intensification of resource exploitation has caused a great deal of forced displacement. The push to acquire access to resource-filled land is a main issue in state violence. 


\section{History}

A brief overview of the history of Colombia will demonstrate the social and political woes at the root of internal displacement. The armed conflict between the state and guerrillas still exists, the dispute over land persists, and "la apertura económica [the economic opening]" (Ahumada Beltrán et al. 2004) of Colombia in the late 1980s and early 1990s through structural adjustment programs (SAPs) create the current context of displacement. As Ibáñes and Querubín (2004:8) argue, in Colombia there is a direct correlation between forced displacement and three main factors: the intensification of the armed conflict in areas of land interest, territorial disputes between paramilitary groups and the guerrilla, and corridors of illicit crop cultivation and the drug trade.

Events occurring since the 1930s within Colombia, and the country's relation to the U.S., have significantly affected today's social, economic, and political problems. After thirty years of government control, the Conservative party lost a presidential election in 1930, giving power to a very strong and united Liberal party. Peasants affiliated with the Liberal party retaliated against past maltreatments throughout the countryside in the course of the following decade with violent attacks on conservatives and land-owning elites. The 1930s also saw the creation of powerful groups of peasants who established and passed economic and agrarian reforms. The government, including many conservatives, welcomed the changes by the groups of peasants, thanks in part to the global depression during the era (Henderson 2001:175). Reforms resulting from popular movements included granting workers the right to 
unionize, socializing credit agencies, and subsidizing coffee production. In 1936, the government passed "Ley 200" (Law 200), legislation that "signaled the transition away from widespread popular acceptance of social hierarchies and notions of distributive justice, toward popular acceptance of individualistic and egalitarian values" (Henderson 2001:212). Campesinos (farmers/peasants) spearheaded the drive for this new legislation.

From 1945 to 1965 , Colombia saw heavy partisan conflict in the rural areas, with at least 200,000 people killed (Roldán 2002) in a country with over 12 million people. This conflict began as a dispute between the Liberal and Conservative parties, with campesinos constituting the majority of combatants and casualties (Sanchez and Meertens 2001; Roldán 2002). From 1948-1958, following the assassination of the Liberal Party's presidential candidate, Jorge Gaitán, in 1948, the era of La Violencia (The Violence) erupted. Many liberals in the countryside experienced a violent backlash from the Conservative Party. Once the elite leadership settled in 1958 on a power-sharing agreement, known as the Frente Nacional (National Front), the conflict appeared to subside. During the 1940s and 1950s, legislation for agrarian reform was rolled back. Campesinos shaped by the earlier violence became social and political fighters, no longer acting exclusively for powerful men above them but in defense of the peasantry and their country (see Roldán 2002).

La Violencia concluded with the creation of the Frente Nacional. From 19581974, the two political parties agreed to share power, with each political party taking office every four years, alternating their time in power. Though the drive to end the 
violence played its role in the creation of the National Front, other interests prevailed. Political and business elites and the Catholic Church formed the National Front principally to maintain power, sustain class interests, and repress working- and middle-class citizens through political action (Palacios 2006:170). In addition, during the Frente Nacional period, agrarian reforms were cut back, and new, similar initiatives were silenced.

Since the 1960s, the Colombian government has waged war against insurgent groups attempting to take control of the country. Groups such as the FARC, ELN, and the ELP $^{5}$ coalesced from early land reform movements that began in the late 1930s and early 1940s. Today, this continuing armed conflict affects much of the population. The effects of the internal conflict in Colombia have been dire. Political assassinations (Gow 2008; Bagley 2005), the overlap between the drug trade and politics (Pearce 1990; Avilés 2006a), wrongful killings of peasants believed to be counterinsurgents (Kline 2007), the use of child combatants (Human Rights Watch 2003), and internal displacement (Rojas Rodriguez 2001; Ahumada Beltrán et al. 2004) have all characterized at one point or another the Colombian conflict since the 1960s.

Public backing, from both campesinos and urban citizens, of insurgent movements waned in the 1980s. This occurred for several reasons. First, following World War II, Colombia became one of the most industrialized nations in Latin

${ }^{5}$ FARC-Fuerzas Armadas Revolucionarias de Colombia (Revolutionary Armed Forces of Colombia). ELN-Ejercito de Liberación Nacional (National Liberation Army). EPL-Ejercito Popular de Liberación (Popular Liberation Army). 
America. Because of its import-substitution industrialization (ISI) policies, Colombia could relax dependence on foreign goods. New factories absorbed many displaced rural citizens during the era of La Violencia. These citizens escaping violence in the countryside became an important labor pool. The influx of new city dwellers urbanized the country tremendously so that by 1980 the country had a $75 \%$ urban population (Henderson 2001:326). Second, this large percentage of urban citizens no longer saw fit to fight for agrarian reform. Not only did the new industrial culture influence urban citizens, it also separated them from the violence and fighting in the jungles, fields, and mountains. City dwellers soon forgot the experience of the conflict, and the struggle that once was a populous movement receded from their collective memories (Henderson 2001:327). Third, the economic policies established in the 1950s produced positive effects in Colombia. The economic policies that Colombia put in place helped the country be the sole nation in Latin America to escape the debt crisis in the 1980s and postponed the adoption of neoliberal economic policies until the 1990s (Gibbs and Leech 2009: 50). Lastly, land-owning elites in the late 1970s and early 1980s formed self-defense groups to protect their lands. These groups, which would later become today's paramilitaries, not only attacked guerrilla factions, which helped reduce their attacks, they also allied with the military and the government to produce policies favorable to their interests, and installed and helped elect political leaders (Medina Gallego and Téllez Ardila 1994; Avilés 2006a; Palacios 2006). The Colombian military, during peace talks with the guerrilla factions during 
the 1980s, worked hand-in-hand with paramilitaries to "effectively [cleanse] entire regions of guerrilla sympathizers" (Palacios 2006:203).

In the late 1980s, the United States cancelled its participation in the International Coffee Agreement (ICA). The decision by the U.S. government had an adverse impact on coffee growers in Colombia. The ICA had "ensured a degree of equality in the power dynamics between poor producing countries and rich consuming nations." (Gibbs and Leech 2009:51). Where once the coffee growers received a guaranteed $\$ 1.20$ per pound, the new price of coffee per pound fell, in the new "supply and demand" global market, to less than the cost to produce it. In order to balance losses, many campesinos turned to the cultivation of coca plants (Thoumi 2002)-the important component in cocaine, produced and exported by urban drug cartels. The Medellín Cartel, and later the Cali Cartel, brought the business of trafficking narcotics to the cities of Colombia. With U.S. backing, the Colombian government fought hard to eradicate cartels. The Andean Initiative, which provided over $\$ 2$ billion of aid between 1989 and 1994 to Colombia from the U.S. to lower illicit-crop cultivation and to fight drug production, "encouraged" Colombia to initiate fundamental economic reform and adopt open-market policies (Gibbs and Leech 2009:50). The last decade has seen the signing of Plan Colombia (discussed in Chapter 3), which seeks to fight drug production and help the Colombia military fight counter-insurgency in the "war on terror." Both the Colombian government and the United States Department of State-along with other international government bodies—define groups like the FARC, and those sympathetic to their cause, as terrorists. 
For over a decade, the Colombian government has passed laws to help those affected by displacement. Laws written on behalf of IDPs are, if not the most, some of the most progressive legislation concerning displaced population or internal refugees in the world. On July 18, 1997 "Ley 387" (Law 387) was passed by the Colombian Congress. This document defines what it is to be displaced and establishes the rights IDPs deserve. According to Ley 387:

A displaced person is someone who has been forced to migrate within the national territory, abandoning his/her place of residence or daily economic activities, because his/her life, physical integrity, security or personal liberty has been violated or directly threatened, within the following situations: the internal armed conflict, disturbances and internal tensions, general violence, massive human rights violations, infractions on international humanitarian law (IHL), or other circumstances arising from the prior situations that can alter or disturb public order. ${ }^{6}$ (Law 387, Title 1, Article 1 [1997])

Ley 387 also pronounces that all IDPs have the right to solicit humanitarian aid; receive basic human rights under international law; not be discriminated against due to their situation, socioeconomic status, ethnic background, language, religion, public and political opinion, place of origin, or disability; reunite with family members lost due to violence; demand due resolution to their problems; return to their place of origin; receive personal security from the government; and move without restriction in

\footnotetext{
6 "Es desplazado toda persona que se ha visto forzada a migrar dentro del territorio nacional abandonando su localidad de residencia o actividades económicas habituales, porque su vida, su integridad física, su seguridad o libertad personales han sido vulneradas o se encuentran directamente amenazadas, con ocasión de cualquiera de las siguientes situaciones: Conflicto armado interno, disturbios y tensiones interiores, violencia generalizada, violaciones masivas de los Derechos Humanos, infracciones al Derecho Internacional Humanitario u otras circunstancias emanadas de las situaciones anteriores que puedan alterar o alteren drásticamente el orden público.” (text translated by author).
} 
the country. In addition, the Colombian government must facilitate all avenues in order for these rights to be met. Sections 3 to 6 (Articles 14 to 17) of Ley 387 establish methods for the government to prevent further displacement, provide humanitarian aid, help people return or resettle in lands of their choosing, and help stabilize IDPs socially and economically.

In 2003, The Constitutional Court of Colombia passed a ruling (T-602) declaring that the government had an obligation to guarantee additional rights to IDPs. Those rights included the access to land, dignified employment, housing, social integration programs in the settlement area, medical attention, adequate nutrition, community-rebuilding initiatives, education, political participation, and protection against actors in the armed conflict.

The Constitutional Court's landmark decision of 2004 (T-025) determined that the Colombian government was falling short of its duties to protect displaced persons and that the state at all levels of government had ignored laws written for IDPs: "These generalized violations were due to structural failures of the government, seen as a whole. Thus, it [the Constitutional Court] declared that an 'unconstitutional state of affairs' had arisen in this field" (Cepeda-Espinoso 2008:3, emphasis in original). T025 has become the normative framework in providing needed attention to IDPs. The ruling declared that national and local authorities must adjust their budgets in order to meet the demands of IDPs. T-025 also requires that groups representing IDPs be allowed to participate in the legal process of improving the "unconstitutional state of affairs." The Court appointed itself to continue to monitor the advancement of the 
laws and to assure that all laws be followed. T-025 also formed steps for the creation of laws directly addressing youth under eighteen (Auto 251 de 2008), AfroColombians (Auto 005 de 2009), people with disabilities (Auto 006 de 2009), women (Auto 092 de 2008), and indigenous populations (Auto 004 de 2009) affected by displacement. These "Autos" (Writs) tackle problems related to these specific populations, which are overrepresented in internal displacement.

Despite positive and progressive laws passed, there is a disconnect between the written legislation and the implementation of law in practice. Laws written on behalf of IDPs have not been followed, and large numbers of IDPs that should have access to funds do not. Though I will not go into detail on Colombia's government branches, let me note here that the judicial branch has passed laws that the executive and legislative branches do not care to enforce.

\section{Lived Reality}

The events transpiring before, during, and after their displacement immensely affect the manner in which IDPs integrate socially and economically into cities like Bogotá. Analyzing the steps newly arrived IDPs take to receive state aid helps understand the lived realities that many experience once they arrive in urban centers.

The majority of the displaced population I spoke with came from rural areas. Most had been campesinos (farmers/peasants) who rented plots of land from a landowning elite or owned land inherited from their parents. Those originally from rural areas had relied on land and natural resources. For instance, many people stated that their sustenance depended on crops (e.g., banana, coffee, rice, yucca, sugarcane, and 
corn) cultivated for consumption or sold in local town markets. In addition, people displaced in all regions of Colombia depended on rivers, and their tributaries, for both water and food.

Numerous violent reasons have caused rural displacement to urban centers in the last two decades. These reasons include: recruitment of adults and youth by armed actors; physical and psychological violence; death threats; torture; murder of family members, friends, neighbors, or bosses; and the belief of armed actors that people are sympathizers of the other, battling armed actors. Urban displacement (either inter- or intra-urban) has grown in the last five years. Violent causes for urban displacement include: militia or gang fighting; domestic violence; threats by paramilitaries; and continued attacks on displaced individuals from armed actors who have branches within urban centers.

Individuals and families must organize themselves and analyze their situation before they choose to flee. They must also have or be able to generate enough liquid assets to make an extensive trip to an urban area or cross the national border into Ecuador, Brazil, or Venezuela (see Engel and Ibáñez 2007). Displacement is "the forced and involuntary exit of place, neighborhood, parcel of land, the fields and the country; it is to abandon everything, to lose culture....[IDPs] are people who have to leave overnight because their lives are in danger" (Cortes S. and Castro de Amaya 2005:33). Once IDPs have been able to create a viable way to flee, the resettling

\footnotetext{
7 "la salida forzosa e involuntaria del sitio, barrio, parcela, del campo o del país, es abandonarlo todo, perder la cultura... [Desplazados] son personas que tienen que salir de la noche a la mañana por que sus vidas corren peligro" (text translated by author).
} 
process is difficult and filled with social stigma that impedes IDPs in the search of adequate housing or that blocks them from acquiring work opportunities. Escaping the effects of violent displacement from one's own home or land may take several years. Many IDPs feel the effects for the rest of their lives.

For those who do not have social networks in place when they arrive in cities, the first glimpse of urban life is the bustling bus terminal where travelers, tourists, and business people scramble through its corridors. If a government worker (who proudly wears a yellow jacket representing the city government) is able to identify a displaced individual or family, the official will be able to direct the displaced person or family to the UAO Bus Terminal Office or the Fundación de Atención al Migrante's (FAMIG, Attention to the Migrant Foundation) office at the bus terminal for immediate help. But, more often than not, IDPs find themselves walking out of the terminal, begging for money on the street and sleeping wherever possible until they find cheap residence or squat on a piece of land on the outskirts of the city to the south. Many people I interviewed related the challenges they had experienced when attempting to find a place to settle in Bogotá.

Relationships with family, friends, or acquaintances who live in the receptor city ease the transition into urban life. Informants stated that relationships and social networks helped them find rooms and apartments, search for jobs through references, navigate through bureaucratic agencies and NGOs, and understand the overall nature of the city itself. However, after a few months of relying on social networks, some interviewees complained that people who had helped them settle into Bogotá were 
beginning to tire of the IDPs' long stay or were asking for financial contributions to the household. Interviewees were neither able to leave the host's house, having no other available housing, nor able to help significantly with household economics. IDPs reported that tensions grew between them and their hosts.

Depending on IDPs' knowledge of the laws, some may declarar (declare) displacement within a few days after arriving in Bogotá, while others may not declare until over a year later. A person may make a declaración (declaration) (see Figure 2.8) in order for the government to classify him or her, and any family, as a persona en situación de desplazamiento (person in situation of displacement/IDP). After making a declaración, a person will receive a letter (Appendix D) stating the date of the declaración, government identification numbers, family members' names, the rights the declared person holds while Acción Social processes the declaration, and the address of the nearest UAO office. Acción Social is the "entity created by the National Government with the intent to channel national and international resources in order to run all social programs that depend on the Presidency of the Republic and that assist vulnerable populations affected by poverty, drug-trafficking, and violence."8

Ley 387 (Law 387) of 1997 established steps to alleviate delays and inefficiencies in the declaration process. With the passing of the law, different

\footnotetext{
8 "la entidad creada por el Gobierno Nacional con el fin de canalizar los recursos nacionales e internacionales para ejecutar todos los programas sociales que dependen de la Presidencia de la República y que atienden a poblaciones vulnerables afectadas por la pobreza, el narcotráfico y la violencia" (Text translated by author). La Agencia Presidencial para la Acción Social y la Cooperación Internacional (The Presidential Agency for Social Action and International Cooperation).
} 
Violent/Traumatic Episode

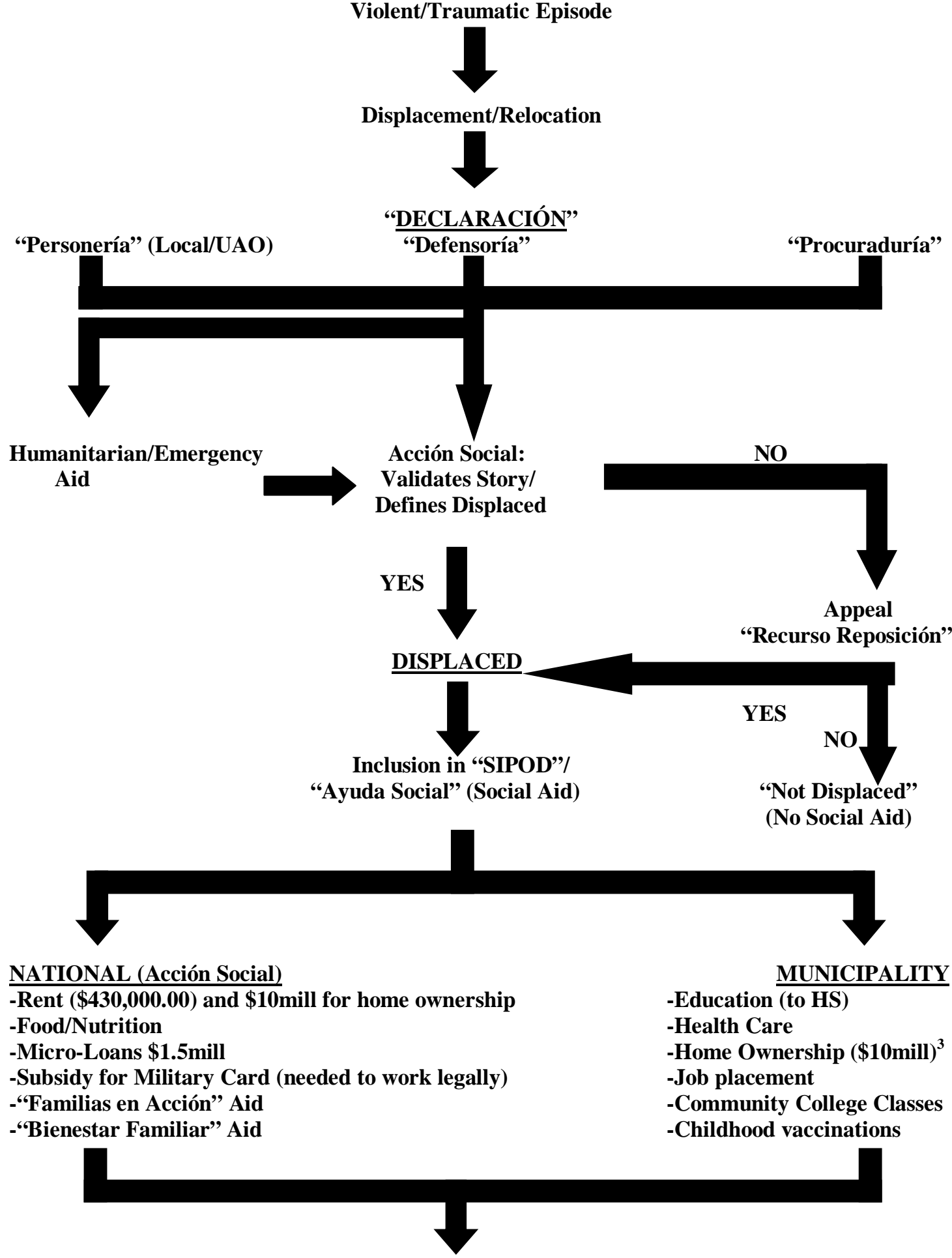

Apply for "Prorroga" (extension of Aid/state visit to home) or Integrated/Sustainable-no longer IDP

Figure 2.8. Steps that displaced people must follow in order to receive state aid. 
government offices were able to receive and collect declaration letters and forward them to Acción Social. A person who wishes to declare can do so at "La Procuraduría General de la Nación" (The Attorney General of the Nation) and "La Defensoría del Pueblo" (The People's Ombudsman) offices located throughout the country. In addition, in Bogotá, people may declare at the "Personería de Bogotá, D.C." (The Municipal Human Rights Representative of Bogotá, D.C.).

These three government offices forward declaration letters to Acción Social, which can take fifteen to forty-five business days to make a decision on whether someone is displaced or not. During the waiting period, the person who declared may receive a one-time emergency bond of 150,000 Colombian pesos (the equivalent to about \$75 US); each UAO office distributes the bonds differently. If, on one hand, Acción Social includes someone in the national registry as a displaced person, the person must head to the UAO office stated on the letter of declaration and register for state aid benefits. The state takes one to five months to distribute aid after registering someone for government aid. Aid comes in the form of rental assistance, nutritional assistance, help in job hunting, help to complete high school, registration at public universities for those who meet requirements, social welfare through childcare and healthcare, and classes at government institutes. Cash assistance (\$430,000 Colombian Pesos, or US \$215) stops after three months. On the other hand, if Acción Social denies inclusion in the national registry, a person has the right to appeal the decision (called "Recurso Reposición") within five business days after he or she has received the letter of denial. If the decision is reversed, the person becomes an official 
IDP. If the appeal is denied, the person may not receive any state aid. However, he or she, like all other IDPs, may seek aid with NGOs (e.g., CODHES, FAMIG, and Red Cross International).

IDPs stop receiving state aid of cash benefits after three months. If the person, and the person's family, needs further aid, he or she may apply for a prorroga (an extension) of continued aid. Acción Social will schedule a home visit to determine if the individual needs the continued state aid. During the home visits the government worker will determine if the household needs further cash assistance or is able to selfsustain. Once an IDP can sustain himself or herself, and family members, without government aid and can achieve socioeconomic stabilization, whether it is at the place of origin or in the resettlement area, the person is no longer considered internally displaced (Law 387, Section 7, Article 18 [1997]).

\section{Conclusion}

This chapter provides a contextual background on historical factors, the armed conflict, economic liberalization, and contemporary land issues in Colombia. The diversity of land features in the country has produced a push for the development of certain industries. Fertile land in the Andes Region; rich, oil deposits in the Llanos; and coal in the Caribbean Region have encouraged new industries to flourish thanks, in part, to the government's liberalization economic policies since the early 1990s. Rural land undeveloped before the 1990s is now home to corporations like Chiquita Brands, Coca-Cola, and Drummond Mining. In the following chapter, I discuss different forms of violence occurring in Colombia. New economic policies have 
caused displacement by allowing transnational companies (such as Drummond Mining, Chiquita Brands, or Coca-Cola) to hire paramilitaries. Paramilitaries have killed union members who seek to create better work conditions; have cleared small towns and killed people who stayed in order for companies to access natural resources; and have fought against guerrillas to safeguard the companies' investments (such as oil pipelines in the Eastern Plains) where people caught in the crossfire are displaced.

The push to acquire resource-rich land displaces some citizens. In addition, the governments' fight against drug trafficking through fumigation and armed conflict displaces many. Armed groups-guerrillas, paramilitaries, gangs, and militiasfighting for control of land displace citizens caught in the crossfire with security forces. Finally, IDPs face daunting tasks in fleeing their land, settling in an urban area, and weaving through the bureaucratic process to receive aid. The violent realities of displacement greatly affect IDPs, becoming an impediment in searching for jobs and shaping identities in urban centers. In the following chapter, I discuss the multiple forms of violence that IDPs experience. 


\section{Chapter 3-Violence: Explaining the Experiences of IDPs Before, During, and}

After Forced Displacement

Forced displacement is a human rights problem closely related to the evolution, characteristics, and dynamics of the internal armed conflict in Colombia ${ }^{9}$ (Rojas Rodríguez 2001:34).

I met Marco on June 16, 2009 at the Ciudad Bolivar-Usme UAO Office. He went that day to seek help in finding his son, recruited to fight for the FARC in the department of Meta ten years earlier. A year after his son was taken away, Marco and his family settled outside a small city in the department of Caldas, located 100km west of Bogotá. There, Marco and the rest of his family worked the land they bought, cultivating bananas, coffee, sugar, potatoes, corn, and cassava. Farming his land, Marco had no need to find another job. He worked the land to sustain himself and his family. He lived in an area of beautiful green fields. Marco's family respected the neighbors, and the families got along. Marco is a skilled woodworker, and was proud that El Tiempo, a national newspaper, had written a story about him. He lived quietly and peacefully on his land before, as he put it, "the war got us." What happened to his son was not the only form of violence the family experienced. He recounted another tale:

I remember the day it happened. I was in my house, and the paramilitaries came. I had had some guerrillas the week before come parading through my house, making me serve them as if they were my masters. That day, the paramilitaries came in and acted as if it was a business transaction [payback for believed sympathizing with guerrilla forces]. They killed my wife in front of me and my children; raped my daughters in front of me and my other son. I couldn't fight back; I

9 “...el desplazamiento forzado es un problema de derechos humanos estrechamente ligado a la evolución, características y dinámicas del conflicto armado interno en Colombia" (text translated by author). 
struggled and cried, but I just kept getting pounded with punches, kicks, and rifle butts. After they were done with my daughters, they killed the other son. As they left, I fought back, with a machete in one hand and protecting myself with the other. I slashed some of them, but they were too many. I got five machete slashes. One was so hard that my arm was barely holding onto the rest of my body [he took off his shirt and showed me his scars]. They gashed open my forearm, stomach, forehead, and upper legs. And if that wasn't enough, one of them shot me twice. I woke in a hospital, screaming for my family. I have lost everything, and I don't think anyone in this city realizes that. I have walked this city for years, and can tell you that people could not care less.

After recovering from his injuries, Marco decided to go to Bogotá and look for his oldest son. Marco obtained a photograph of his son and shows it to everyone with whom he starts a conversation. (The photograph shows his son at the age of thirteen in FARC uniform holding a rifle). Marco's life history is hard to hear, and the experiences he recounts are hard to conceive. The hardships he has lived through are not limited to the physically violent acts that transpired with the paramilitaries or the kidnapping of his son by the FARC. He also lives with cultural modes of controlsymbolic violence-in his everyday life in Bogotá. Marco told me that people perceive him as different because he lives on the streets. He claims that the public does not respect him and spits at him because he is displaced.

\section{Overview}

Marco's narrative demonstrates all the forms of violence that displaced people live through in Colombia. This chapter describes the violence internally displaced persons (IDPs) experience before, during, and after displacement from their homes and lands. It examines overlapping forms violence-state-sanctioned, insurgent, 
structural, and symbolic_illustrated with ethnographic accounts. These forms of violence affect the livelihoods of IDPs. They also affect how IDP identity is recreated and redefined by IDPs themselves, the non-displaced public, and the government.

Before discussing the atrocities experienced by many IDPs in Colombia, a brief discussion of three forms of violence will be helpful. State, structural, and symbolic violence are everyday realities for many IDPs. These three forms of violence, separated here for analytic purposes, interrelate with and overlap with one another in practice. These are not the only forms that violence takes in Colombia. However, these are the forms I identified repeatedly in discussions regarding IDPs. Neoliberal, economic development strategies, militarization, and victim-blaming discourses allow non-displaced persons to discriminate publicly against IDPs. As this chapter will show, the realities of militarization, asymmetrical economic development, and 'othering' create a discourse that argues that IDPs deserve their degraded state. The discourse also creates a lived reality that assures that there will be no challenge to the current state of affairs that causes contemporary displacement. My main focus here is on the symbolic violence that IDPs experience after relocation. Through ethnographic date, I explore how IDPs themselves relate to the state and non-displaced public; how their identity and sense of self change; and how they experience and react to prejudice in Bogotá. My work thus contributes to the ongoing anthropological debates at the intersections of the study of violence and the study of identity.

Before going into depth on different forms of violence, let me again note that I separate state, structural, and symbolic violence in this study solely as analytical 
categories of research for a theoretical discussion. In reality, violent events experienced by displaced persons have aspect of all these forms of violence.

\section{The Internal Armed Conflict: State and Insurgent Violence}

State violence is violence created or supported by a government against perceived enemies. Lauding it as necessary, states perform violence under the guise of security and national defense. In Colombia, the government has killed innocent people and claimed those actions necessary for national security; has financially backed paramilitaries for decades; and has detained believed guerrilla sympathizers without due process. State violence also creates human rights violations.

The Colombian state currently focuses on a discourse of national security, both in economic development and military actions. This discourse creates state violence through a doctrine of seguridad democrática (democratic security). This policy, enacted in 2002 by current president Álvaro Uribe Vélez, puts forward the notion that Colombian society should be more active in the government's fight against threats from illegal, armed actors - that is, that the citizenry is responsible for protecting the state by fighting insurgency (Uribe Vélez 2003:5). La seguridad democrática also argues that the state should be able to strengthen its military forces and spread them throughout the national territory.

The government claims that the policy has succeeded, but critics suggest that it has done more harm than good. ${ }^{10}$ It is on this idea of national security that the

\footnotetext{
${ }^{10}$ In the 2008, the scandal of falsos positives (false positives) shocked the country and the international community. It was found that many military personnel were rounding up people from poor neighborhoods of Bogotá and the neighboring city of Soacha, including some IDPs, in the pretext that
} 
government legitimates its actions, creating what Agamben (2005) calls the state of exception. Under pretext of an emergency, a government implements a state of exception that takes away liberties and rights that are defined and (normally) protected by constitutional powers. For example, when President Uribe took office, he ordered the creation of "rehabilitation zones" in which security forces operated with impunity and held 4,362 citizens in "arbitrary detention" for the first year of Uribe's presidency (Avilés 2006b:405). In Colombia, Congress has allowed President Uribe to fight for national security by spreading war throughout the country; to change the constitution for reelections; and to define who is Colombian and who is not, thus defining who is allowed to receive the benefits of the law: "This [democratic security] will be an effort of the whole state, of all Colombians" ${ }^{11}$ (Uribe Vélez 2003:7). Such a statement infers that those who participate in democratic security are Colombians, and that those who do not are not part of the nation.

The national security discourse in Colombia argues that the military must fight in every corner of the country and that the public must fight along with it in order to regain the territory and power that the state lost due to insurgents (Uribe Vélez 2003:5). The "suspension of the order that is in force in order to guarantee its existence" (Agamben 2005:31) is a defining characteristic of Agamben's state of exception. In the case of Colombia, we see the paradoxical loss of security and order

they were receiving jobs in farms. The military personnel then tortured, murdered, and dressed those individuals in FARC uniform to create the idea that the government's policy of seguridad democrática was working.

11 "Este va a ser un esfuerzo [la seguridad democrática (democratic security)] de todo el Estado, de todos los Colombianos" (text translated by author). 
in adhering to the doctrine of Democratic Security so that the Colombian state may once again regain the security and order that it claims has been lost due to armed insurgents (Uribe Vélez 2003).

During the last forty-six years, Colombia has endured violent conflict between the state military and insurgency movements that seek to change the government. Because of the changes, dynamics, and characteristics of the internal conflict occurring since the late 1980s and early 1990s, the internal conflict has become the major contributor of rural displacement (Rojas Rodriguez 2001).

In the late 1980s and 1990s, the Colombian government shifted its internal government policy toward a more civilian dominated state and away from militaryheaded institutions. This occurred by creating "civilian supervision and direction over the behaviour and operation of the armed forces..., reducing the institutional role and responsibilities of the military" (Avilés 2006b:381). One example was that in 1991, a civilian replaced the military head of the Departamento Administrativo de Seguridad (DAS), the country's domestic intelligence agency. In addition, the 1991 Constitution allows the participation in government of political parties besides the majority Conservative and Liberal parties. This allowed the Colombian government to become more inclusive of political parties and to ease its integration into the global economy by ostensibly demonstrating open democratic views and curtailing human rights violations (Avilés 2006b).

After the shift to civilian control in military procedures, a new characteristic in Colombia's internal conflict surfaced. The Colombian government still had to counter 
strong insurgency from guerrilla factions. One way in which the government dealt with insurgency was by allying itself with paramilitary groups. By allying itself with paramilitaries, the Colombian government claimed fewer violations from its forces. However, paramilitary forces supported by the government violently attacked guerrillas or people sympathetic to guerrilla causes. Injustices caused by newlyformed paramilitary units increased the prevalence of human rights violations and the high numbers of internally displaced, problems which persist today. Today, the government continues to permit and to (financially and tactically) support attacks undertaken by provincial and local paramilitary groups. Many of these attacks by paramilitary forces target suspected guerrilla sympathizers and are characterized by torture, murder, threats, and forced recruitment of youth. In addition, these human rights violations continue without punishment from the government. Avilés argues that since 1993 "increasing violations of human rights by paramilitary groups [correspond] with a decrease in the number of direct violations of human rights committed by the armed forces" (2006b:402, emphasis in original). Backing and allowing attacks by paramilitary factions, along with mounting human rights violations, is the essence of state violence.

Consider the following example of government-paramilitary collaboration. Jorge, a 40-year-old Afro-Colombian whom I interviewed, stated that paramilitary groups in his department of Cauca went unpunished even though state police and military knew of paramilitary abuses. Jorge was displaced after paramilitary forces killed his brother in retaliation because Jorge himself refused to join ranks with the 
paramilitary forces where he lived. After telling local authorities and realizing that no action was going to be taken for the murder of his brother, Jorge, his wife, and three daughters left the region and fled to Bogotá. His mother, who still resides at his home in Cauca, tells Jorge that the authorities have done nothing in relation to the murder of his brother. This example suggests that paramilitary forces operate with the implicit consent of the government.

Due to the impunity given to paramilitaries (Zur 1994; Afflitto 2000), guerrilla groups such as the FARC and ELN have intensified their attacks and recruitment tactics. Guerrillas have begun to recruit youth to fight for their cause, and families that do not cooperate experience violence leading to displacement from their homes. Xiomara, with eyes full of tears, discussed the night in which she was sexually threatened by FARC forces. She recounts that "the guerrilla threatened the life of my children if I did not sleep with one of them and allow them to take one of the boys."12 She told me that she did not experience any physical violence because the guerrilla group who took over her house was called to another post. Xiomara escaped during the night, and an inter-city bus driver gave her and her children a ride to Bogotá. This suggests that the government's use of paramilitaries in counterinsurgency tactics cause similarly violent responses and resistance among guerrillas, and civilians get caught in between.

The Colombian military has financed and supported paramilitary violence against insurgent groups (Medina Gallego and Téllez Ardila 1994). The military uses

12 "la guerrilla me amenazo la vida de mis hijos si no me acostaba con uno y dejara que se llevaran a uno de los niños." (text translated by author). 
paramilitaries as "tools of economic interests in order to access territories and resources" (Gruner 2007:167) and, thus, the military is not officially accountable for wrongdoings in human rights violations. For example, paramilitaries attack FARC strongholds in the department of Arauca. This region has lots of pipelines that the government desires to safeguard. In addition, in the department of Sucre, politicians worked together with paramilitary units. In other areas where there is no state presence, paramilitaries are allowed to operate (BBC, August 2, 2008).

In 1999, Colombia and the United States created a policy known as Plan Colombia to replace drug cultivation with direct aid and development strategies. However, Plan Colombia has transformed from a development plan emphasizing crop substitution and alternative economic programs into a military strategy focused on combating insurgency (Rojas 2005:217). For example, the three main objectives of Plan Colombia - to reduce coca cultivation by fifty percent in five years, to end the internal conflict, and to strengthen Colombia's economy-are implemented primarily through attacks on FARC-controlled territory (Gibbs and Leech 2009:53). Consolidation between paramilitaries and the Colombian government has created state sponsored violence against peasants who are believed to support guerrilla movements. In addition, the United States began to help the Colombian state wage war against guerrilla movements first to combat communism and later, in the 1980s, as a war on drugs (Avilés 2006a:47). The money from the sale of drugs is used by both guerrillas and paramilitaries to fund their activities. 
Since 2001, the United States has continued giving aid to Colombia through Plan Colombia, now under the aegis of the war on terror (and since March 2009, under the new "Overseas Contingency Operations"). Close to eighty percent of the aid that the United States provided Colombia between 2000 and 2004 funded military and counter-insurgency endeavors (Meltzer and Rojas 2005:7). Poor peasants and ethnic minorities caught in the crossfire between the state and insurgency groups, like Juan Bautista and Xiomara, are often displaced as a result of military and counterinsurgency endeavors.

Displacement is happening in several ways. First, many, like Marco above, shared tragic stories in which the armed groups fighting for control of land and resources violently displace individuals or family who are believed to sympathize with the enemy. The state has allowed paramilitary groups to act freely and remain exempt from punishment. Impunity causes continued violence (Zur 1994). These experiences affect the ways in which people integrate socially and economically in the city of Bogotá. For example, IDPs did not trust the government agencies in their original homes to provide overall security and punish those responsible for violence. Thus, when IDPs arrive in urban centers, they bring their distrust of government institutions with them.

A second way that people are displaced is through the fumigation of illicit crops in FARC-controlled territory. Vargas Meza (2001:68) discusses negative effects on both the environment and human health caused by fumigation. Because fumigation of illicit cultivation with deadly pesticides is part of the strategy in Plan Colombia, 
rural citizens often receive the ill consequences of such practices and must flee their homes. Suffering takes place in many ways: social and family networks, physical health, and land are all damaged by fumigation.

Bernardo, the IDP recruited forcefully from his home to fight for the FARC, shared his views on the current armed conflict that has transpired for the last 40 years. Bernardo believed that everything was a lie. Whether it was the military, paramilitary, or the guerrillas, all actors involved simply wanted to spew propaganda for their side. "They are all lying," Bernard said. Bernardo felt like the actors involved in the armed conflict were only interested in their own ends. In addition, Bernardo believed that the government lied to the country. He recounted that he laughs every time he hears the president or any member of the armed forces claiming that the government is winning the fight against the guerrillas. Bernardo told me that the numbers and networks that the FARC have, for example, are not dwindling. Bernardo's example illustrates issues of propaganda of all actors, rumors, and the trust that dwindles between the state and the citizens.

\section{Economic and Development Strategies: Structural Violence}

Structural violence is systematic violence performed by social institutions and the actors within those institutions (Farmer 2004:307). It creates large scale inequalities that cause oppression. Structural violence marginalizes people. In this form of violence, social institutions exclude people politically, dominate people socially, deny people access to social services and welfare, and exploit them for 
economic gains (Farmer 2004). Institutions that perform structural violence include governments, international bodies of development, and local municipal offices.

A political economy approach to the study of violence allows an understanding of the relations between economic (under)development, consumption, and production on the one hand and politics, jurisprudence, and government on the other. It allows us to examine past economic and social history to better understand the present socioeconomic situation (Frank 1970) (see Chapter 2). By examining neoliberalism as a form of structural violence, we may see how it affects Colombia socially and economically, as well as the effects it has on integration of IDPs in the urban centers of Colombia.

Neoliberalism is a socioeconomic policy that seeks to transfer economic control from the public and state to the private sector. Government officials implement neoliberalism through the rollback of state subsidies and programs by, for example, cutting social and welfare programs (Gledhill 2007; Lutz 2007). Neoliberal reforms open markets, creating a favorable environment for private (transnational) corporations to invest. Neoliberal reforms are performed with the belief that they will close the gap between the rich and poor. Though many Latin American countries adopted structural adjustment programs (SAPs) tied to neoliberalism to combat their failing economies in the 1980s, Colombia did not experience the same woes and only adopted this socioeconomic policy a decade later.

It was not until the late 1980s and 1990s that the Colombian government began its war on drugs and adopted a new Constitution to reflect cultural pluralism and a 
more democratic government. It also defined Colombian identity against guerrilla movements and drug traffickers at the same time that new economic and development policies were adopted. One way the Colombian government received foreign aid was by stepping up its military pressure against the war on drugs. In 1989, the Andean Regional Initiative was created to combat the drug-trade. The aid came in the form of military equipment and training, totaling $\$ 2.2$ billion in the first five years (Advocacy and U.S. Foreign Policy). In 1991, to align itself with a more individual and market economy, the government rewrote the constitution with a more pro-democratic and U.S. backed ideology (Avilés 2006b:389). The new political leaders during this era promoted democracy in order to combat "the continuing challenges of social protest, guerrilla violence, and narcoterrorism" (Avilés 2006b:388). The war on drugs helped the government find an enemy in order to justify the need for foreign aid tied to development, political ideology, and militarization. Encouraging the shift to a more democratic government styled after the U.S., the U.S. saw the need to defend political allies with monetary and military aid. Those who stood in the way-drug-traffickers, activists against the state, and guerrillas—-were transformed into 'others' who were not Colombian.

Gledhill describes the neoliberal era as the time when "capitalism deepened to embrace the production of social life itself, seeking to commoditize the most intimate of human relations and the production of identity and personhood" (2007:340). Colombia is a clear example. In the early 1990s the Colombian government opened its economy to foreign, capitalist investment. With the help of the government, 
foreign corporations weakened "labour and popular movements through presidential decrees and articles in the new constitution....Government spokesmen frequently charged labour leaders with terrorist acts when they engaged in social protest" (Avilés 2006b:391). Capitalism deepened in Colombia to increase profits. In addition, the government labeled workers who sought just wages and fair treatment as terrorists. Neoliberal economic policies have created a form of state militarization against workers who were once protected and represented by the state itself.

The displaced in Colombia arrive in urban centers and attempt to participate in a market economy that many have not previously experienced. The "virtues of 'competition"” (Gledhill 2007:340), exalted by capitalism, are new concepts to many who have never been part of the labor economy. People interviewed in this study remarked how wage work was impossible to obtain, and that they belonged in $e l$ campo (the fields). In addition, "the production of social life"-identity itself-affects how urban non-displaced citizens and the government categorize IDPs. The nondisplaced public has negative perceptions of those who live at the margins of society. As I show in this chapter, IDPs do not integrate in the market economy because of obstructions due to education, experience, or lack of references and must participate in an informal economy as street vendors or jornaleros (day laborers).

Political economic analysis of the conflict in Colombia suggests that it has its roots in structural violence. Suppression of resistance by the state is tied to the economic projects, which cause inequality, that the state wishes to implement. In Colombia, the drug war coincided with a push for the economic liberalization of Latin 
American economies (Avilés 2006a:49; Leal Buitrago 1995). The employment of paramilitaries is possible due to international aid initiatives like Plan Colombia. Guerrilla groups support the cultivation of illicit crops as a means of taxation, and the Colombian state receives aid in order to fight the war on drugs. Aid, through Plan Colombia, can only be received with the adoption of neoliberal economic policies affirmed by the United States (Gibbs and Leech 2009). As elsewhere, the United States offers arms and military training in exchange for resources, commodities, and a pool of cheap labor (Lutz 2007:323). In recent years, multinational corporations such as Chiquita Brands and the Coca-Cola Corporation have taken advantage of the new open economic atmosphere in Colombia. Such companies have used force to quell resistance from workers who fight against horrid work conditions. Chiquita Brands recently settled for $\$ 25$ million in court for worker abuse and the hiring of paramilitary death squads to kill union bosses and members (Clark 2007). Militarization is valued in the neoliberal model not only as a means to safeguard national security in developing countries, but also as a way for developed countries to garner resources from underdeveloped states that receive arms (Stokes 2005). Financial and military aid has continued to pour into Colombia from the United States, with an understanding that the money will be used for neoliberal development and investment strategies (Gruner 2007:156; see also Black 1999; Schaffer 1995; Escobar 1988), while the elite Colombian nationals continue to support and benefit from neoliberal policies.

Another form of structural violence exists for many IDPs at UAO offices throughout the city of Bogotá. Government agencies at UAO offices create labyrinths 
of bureaucratic steps that hinder IDPs from receiving state aid-a hindrance that exists despite the foreign aid dumped into endeavors that create large numbers of IDPs. IDPs who I spoke with told me that lines at the UAO were long, and they had to come at early hours of the morning to have a chance to meet government officials. I witnessed how government representatives talked down to many people who visited the offices at Ciudad Bolivar-Usme and Bosa-Kennedy. Patricia, an IDP from the Llanos, recounted that in her visits to the UAO, the government agents that she interacted with yelled at her because they did not believe what she told them. In one case, the official, without looking at her National Identification Card, said that her ID was illegal and forged.

These occurrences in Colombia and within the UAO demonstrate a connection between large-scale government militarization and neoliberal economics on one hand, and the proliferation of IDPs and their poor treatment in government offices on the other. While the government adopts measures in order to be able to receive foreign aid, people who suffer as a result of such measures are not receiving adequate assistance.

\section{The Formation of the IDP Other: Symbolic Violence}

Symbolic violence is violence through social modes of control (Bourdieu

1994). It forms categories of dominance through strategies of power or discrimination. People place and impose categories onto others to exert power. When one person misrecognizes the other, and denies equal footing, symbolic violence 
occurs (Rojas 2005). Symbolic violence, through discriminatory practices, becomes embedded in social institutions.

The non-displaced public views IDPs as non-citizens and as people who use up resources. IDPs also have their identities erased and recreated through symbolic violence. Malkki's (1992) theoretical essay on refugees and their "uprootedness" brings to light how refugees' identity is formed. Malkki's analysis of events in Tanzania parallels what is taking place in Colombia. She argues that people see refugees as amoral populations, believe that by losing their physical homeland they lose their moral bearings (Malkki 1992:32). The loss of morals becomes a consequence of loss of homeland, a state of uprootedness. Those "broken roots [displacement from home] signal an ailing cultural identity and a damaged nationality" (Malkki 1992:34). Many see IDPs within Colombia in the same manner, as refugees within their own homeland. The public at large condemns them, and defines them as vagrants, people who have adopted a way life different from the rest of the culture. The government argues-despite the written law-that most of those arriving in Bogotá are not IDPs; rather, it argues that they are poor job seekers ineligible for government aid (Gonzales Bustelo 2005). In such cases, 'othering' serves economic and political purposes; it points to the individualization of responsibility characteristic of neoliberal economic policy and of the democratic security discourse exalted by the government.

Theorists see 'othering' as a way to assign essential ideas and definitions to others in order to demarcate difference and exert control. 'Othering,' attempting to 
define the self identity as positive by defining the other identity as negative, prevails today in Colombia. The non-displaced public performing 'othering' creates both a stigmatized identity of the other and an identity of themselves as everything the other is not. By 'othering,' people are able to exert power and control over marginalized groups by belittling and making others' actions immoral. In Colombia, examples of 'othering' include "invasion" and "street vendors" narratives that I discuss later in this chapter. Additionally, 'othering' explains perceived anomalies inherent in an imagined world view (Biolsi 2007:402). Perceived anomalies can be a number of things; for example, in Colombia 'othering' discourses address why displaced persons are poor and uneducated compared to the rest of society; why people's displaced situation occurs; or why IDPs' work habits are reason enough not to provide work opportunities. 'Othering,' or the cultural construction of identity, leads to the normalization of violent behaviors, discussed further in Chapter 4.

In the 1990s, one of the most prevalent forms of violence in Colombia was the manifestation of social cleansing (limpieza social). This form of violence started with 'othering' of people that were not seen in positive light, and, later, evolved into actual, physical violence. This form of violence shows the overlap between symbolic and state violence in Colombia. Much of the public that witnessed such atrocities approved of this movement as many communities felt that drug dealing, poverty, homosexuality, and petty crimes were negative elements that needed elimination (Franco 1999). People did not desire the government to prosecute limpieza social violence, and most individuals supported such actions. These actions were carried out 
by paramilitary forces, self-defense groups, and militias who were helped and protected by the state and local governments. To this end, poor, homeless, orphaned children (gaminos) who often were believed to use drugs were murdered on the street and their bodies left to rot. Homosexuals were not a desired part of the Colombian state, so they were also targeted for this social genocide. Indigents, believed to bring the community a negative image, were rounded up, murdered, and shown as the types of individuals that the country did not want. Small time drugs dealers were also on the cleansing agenda, along with any other individual who did not fit the ideal image. These included prostitutes, petty criminals, drug addicts, youth gangs, and garbage pickers. Social cleansing-itself a euphemism for murder-created a notion of deserving citizen, someone who earned state protection. Protected by state forces, social cleansing actions intertwine symbolic and state violence.

Internally displaced persons (IDPs) in Colombia experience symbolic violence from government offices and officials, potential employers, and the urban nondisplaced public. One way this happens is through 'othering.' Discrimination, a type of symbolic violence, is a lived experience for many who come to Bogotá. Through the appropriation of their testimony by governmental agencies, and through public discourse on displaced individuals, IDPs live a new form of violence when resettling. The gathering of stories from IDPs by the state allows the reconstruction of history by those in power (Castillejo Cuéllar 2007:77). Those in power take stories and decide whether a person tells the truth or not, and, ultimately, responsible if someone receives aid or not. In addition, similar to the ways in which the public approved of social 
cleansing, the popular discourse does not recognize the violent events that IDPs have experienced. Instead, it argues that the state aid IDPs receive is wasteful and categorizes IDPs as invaders or indigents. This public discourse allows and justifies further structural and state violence against IDPs. As Marco states:

I am living at Parque Tercer Milenio right now. It is hard asking for money, or shoes. Just last week, some guy gave me a pair of boots. Nice gesture, but they couldn't be used; neither had soles. I nearly threw them back at the guy's face. People don't care. I didn't go hungry in the fields (campo). There was always food. If you were hungry someone gave you food. Bogotá is very cruel. Tell me, who is going to take care of un desplazado [an IDP]? Sometimes I go up to Plaza Bolivar [the main square in Bogotá, where the country's principal government offices are located], and see all those guys in their business suits. They don't care about me, or the others who took over Parque Tercer Milenio [a city park near Plaza Bolivar; discussed in Chapter 5]. They spit at me some times. Working is impossible, and begging is shameful. Not only that, I try to speak to people, sell what I make with my hands, but they don't want me near them. They think I smell bad, or perhaps that if I get close I will mug them.

Narratives from members of the non-displaced public and government workers show that Marco's perceptions are accurate. The IDP population is viewed as a drain on the city, with individuals caricatured as lazy panhandlers, con men, drug dealers, and dangerous criminals by the non-displaced public. Gracia, a woman in her late 50s, lives in the locality of Chapinero, in an upper-middle class neighborhood. She lives in a higher social stratum, and owns her own business. Her answers when asked in May 2009 about her opinions on the displaced mirrored those held by many non-displaced individuals. Gracia said:

There are still displaced people? I thought that they all went back to the fields. Well, anyways, you can't believe what they say. One time my 
husband and I helped out a displaced family, but they did not do anything. We told them to take care of a lot for us-because my husband, an architect, had been contracted to build a house-so they could live somewhere while they found another place to live. But they would lie to us, and one time something very bad happened. ${ }^{13}$

Gracia's comments, like those of other individuals, show that displacement is not an important subject in the public's mind. In addition, she generalizes her bad experience with one family to the rest of the displaced population.

Many non-displaced people in Bogotá talked about the access to education given to IDP children. Non-displaced citizens often related how they believed children displaced did not deserve spots at schools in Bogotá because they were not from Bogotá and their parents were not really displaced. For example, Marcela, a 27year-old college student from Bogotá, discussed her perceptions of IDPs in relation to education during a dinner-time focus group. She stated that the children of IDPs had no right to take the spots of children from Bogotá at local schools. She argued that many IDPs, despite the law stating that they deserve access to education, were simply a burden and that their situation was not going to change. Marcela described IDPs as people who could not be educated because of their rural background. She felt that providing education was a waste of government funds. To Marcela, IDPs did not deserve education and access to rights that others she identifies with are worthy of. She believed that IDPs belong in the marginal settings of the city or in rural areas.

\footnotetext{
13 “'Todavía hay desplazados? Pensé que ya se habían regresado al campo. De todas maneras, uno no les puede creer. Una vez mi esposo y yo le ayudamos a una familia desplazada, pero no hacían nada. Le decíamos que cuidaran un lote-por que mi esposo como arquitecto lo habían contratado para construir una casa-para que pudieran vivir en algún lado mientras que conseguían otro lugar donde vivir. Pero nos mentían, y una vez algo paso y los tuvimos que despedir." (Text translated by author).
} 
Here, Marcela by defining her 'self' identity as a "Bogotana" by describing what the 'other,' displaced person is taking away, allowed a continuing idea that IDPs do not deserve state help and that further structural violence is permissible. Some of the people in the focus group nodded, while the rest kept quiet.

Government workers' accounts contrast with IDP narratives by arguing that IDPs are greedy, arriving in the city seeking the free money that the district of Bogotá hands out. Carlos's account was typical of those told by government functionaries. Carlos, a government worker at the Ciudad Bolivar-Usme UAO office, was the person in charge of handing out emergency funds to those in need. In our numerous conversations, Carlos often talked about how stressful the job was because many IDPs lied to him. Carlos described IDPs as "cow farmers," saying they were milking the state for all its money. (He would even act out the action of milking whenever he said this). Carlos saw IDPs as liars and defined IDPs as only interested in money. Carlos, who stated that he stopped asking people the reason behind displacement because he would feel depressed, erased their lived experiences and the reasons behind their situation. He simply stigmatized the IDP population as people stealing money from the state.

It is these sentiments of rejection towards displaced persons from both public citizens and government officials on which future work should focus. How and why do these populations come to be seen in this manner? What factors cause the harmful classification and stigmatization? What reasons are behind the denial of government aid? 'Othering' convinces non-displaced people that IDPs are different, lesser, 
degraded, and undeserving of state aid because they cannot escape from their past experiences. Thus, the popular discourse declares that the IDPs' homeless, shoeless, uneducated existence befits them. The belief then forms that IDPs are undeserving and IDPs who seek aid are only in it for the money. No one, not even the government officials in charge of helping them, really challenges the discourse. That means that neoliberalism and state violence can also continue unchallenged.

\section{Conclusion}

In this chapter I have laid out a way to understand violence in Colombia. State, structural, and symbolic violence coincide with and overlap with one another, though I separate them in this discussion as useful categorical devices. The state exerts violence through demonization of rural workers and farmers into sympathizers of guerrillas. In Colombia, the government has pushed a doctrine of Democratic Security, which places citizens in the middle of the 40 -year-old armed conflict. In addition, the state has utilized paramilitary forces in order to combat insurgents, while holding an image of defending human rights.

Structural violence creates uneven distribution of power. Structural violence comes in the form of resource-rich land utilized solely for the development of corporations. Thanks, in part, to liberalizing the economy, development projects have begun throughout Colombia. Since 1999, Plan Colombia's supporters have utilized foreign aid money to back paramilitary attacks on guerrillas under the guises of the wars on terror and drugs. People resist economic policies that have had adverse 
effects, which in turn, the state then creates violence in the form of counter-insurgent tactics.

Symbolic violence is violence that must be disguised through different strategies of control, and, as such, symbolic acts of violence (like social cleansing) are euphemized (Bourdieu 1994:184). In Bogotá, the state and the non-displaced public categorize and define IDPs negatively. Symbolic violence is discrimination; sometimes that discrimination has economic and political ramifications. Symbolic violence justifies state and structural violence. Symbolic violence also defines the IDP other as a liar, a thief, and a person incapable of working in the city. Denying someone the means of making a living is structural violence.

IDPs bear the brunt of these forms of violence, and have to navigate in places where people do not necessarily see them as valued citizens. Economic policies have adversely affected the situation of many poor peasants and ethnic minorities. With mounting pressure due to the marriage of self-defense groups to government forces, people have to escape or leave-as internally displaced persons or refugees—so they are not assassinated, punished, driven out by fumigation, or tortured (Salcedo 2005:164). However, after escaping and resettling, 'othering' occurs, making integration difficult. IDPs are caught in the middle of a war between the guerrillas and a state funded by foreign aid. For many of the IDPs who answered my questions, these daunting challenges have become a normal part of life. The following chapter discusses identity formations of IDPs. It highlights key issues on state categorization, self-identification, and social solidarity. 


\section{Chapter 4-Internally Displaced Persons' Identity Formations}

Forced displacement is a tragedy that has repeated itself....It is the construction of a new vulnerable society; the displaced population is the most vulnerable of the vulnerable, and the poorest of the poor. Eighty-two percent of the [displaced] population lives below the extreme poverty line. ${ }^{14}$ (Garay, April 23, 2009).

The term "identity" carries many ambiguities, and teasing out the different notions of the term helps isolate more robust concepts for analysis. Here, I avoid taking identity as a fixed, unchangeable cultural characteristic of specific groups of people (Borda Carulla 2007). Instead, I understand identity as social construction formed by the interactions between individuals or groups of people (Borda Carulla 2007:43). Social construction of identity of internally displaced persons (IDPs) by other actors takes the form of negative stereotyping through symbolic violence. IDPs react to stereotyping through self-understanding of belonging to the place of displacement, which differs from urban centers. In this chapter, I investigate how IDPs respond to such categorization and construct their own individual and group identities.

For example, consider the issues of identity in the following narrative. Similar to other IDPs, Nancy has been violently displaced from her home twice. I met her just a month after she had arrived in Bogotá a second time. Several reasons contribute to Nancy's multiple displacement: her resettlement in a rural area and a part of the city where general violence was prominent; networks of militias, paramilitaries, or

\footnotetext{
14 "El desplazamiento es una tragedia, que se ha repetido...es la construcción de una nueva sociedad vulnerable; la población desplazada es la más vulnerable de las más vulnerables, la más pobre de las más pobres. El ochenta y dos porciento de la población [desplazada] esta debajo la línea de extrema pobreza." (Text above translated by author).
} 
guerrillas responsible for the first displacement remained active; job opportunities were scarce; Law 387 and T-025 that guarantee human rights were not followed. These reasons made integration economically and socially difficult. When I spoke with her in 2009, Nancy, 36 years of age, from the department of Meta, had just resettled in the cold city of Bogotá.

Nancy's first displacement occurred toward the end of the year 2000. She and her husband had found jobs deep in Llano territory, known for its guerrilla activity, working in a finca (a plantation/large farm). After their three-month stint as jornaleros (day laborers) in the Llanos, both returned to their home. Within a week of their return, paramilitaries knocked on their door. Masked, they rammed through the door when no one answered fast enough. Threats and blows fell upon all family members. The paramilitaries ordered Nancy—believed to be an informant for the FARC after her work in the Llanos—and her family to abandon their home and land. Nancy, her husband, and her three children attempted to resettle in Bogotá, but within three months they returned to Meta. Bogotá did not provide them with any safe solutions. Not only was the weather very cold and unwelcoming; according to Nancy, the people were the same. Not one person helped them with food, clothes, or finding jobs. The government office where she declared ${ }^{15}$ for the first time did not direct her to places where she could be helped, and she never received any government aid. Dissatisfied with the situation in Bogotá, Nancy and her family returned to Meta.

\footnotetext{
${ }^{15}$ I discuss the declaration process in detail in chapter two. An IDP declares displacement in order to get recognition from the state that he or she, and his or her family, have been displaced due to violence. After declaring to a government official, a person classified as a displaced person may receive government funds, healthcare, and education.
} 
They squatted on the land outside of Meta's capital after they left Bogotá and made it their home for nine years.

Her second displacement occurred one month prior to our first interview.

Crying, sobbing, and speaking through the pain, she shared her story:

"We were in our rancho [tent/makeshift homes often built on squatted land, and the word often used by IDPs], cleaning up the kitchen after lunch that day. My husband and our children were just talking and helping each other, when five paracos [short for paramilitary] busted through our door. They grabbed my husband first, and just started beating him. My oldest son tried to stand up and help his dad, but one of them gave him a blow that sent him to the ground. 'You think you are a man! You think you are a man!' yelled the masked man at my son. I was helpless, as my other son held me back. I could not even protect my own son. They told us we had three days to leave our house, or suffer the consequences. I asked what we had done, but they simply said 'it is best you don't ask.' We have been in Bogotá for a month now. I had no idea about the UAO or the aid they gave until one of my mother's friends living here told us. No one told me last time. The thing that I feel the worst about, what keeps going through my mind every second, is not being able to provide food for my children-I have not eaten in two days just so they may eat something. We left without clothes, bringing just what we had on our backs. We barely have any food, and seeing them hungry kills me. I wanted to work cleaning bathrooms at a restaurant near the room we are renting, but after I mentioned that I am displaced, the owner said no. There is too much prejudice against the displaced."

For a second time now, Nancy has been trying to integrate into the city of Bogotá. Her biggest complaint about the city remains its cold people and weather. She talks about the cold water in the morning. Bogotá's high altitude makes the city very cold. In the morning, temperatures can dip into the low 40s Fahrenheit (4-9 degrees Celsius). Despite the temperature and lack of hot water, Nancy always takes a shower because that is what her mother taught her to do. She finds the people in Bogotá the 
same as its weather. According to her narrative, people do not care about the displaced; the city's citizens are cold and inhospitable. They only see what is outside and not the experience. "It is better to die in one's land than to live in a place where nobody wants us."16

Nancy's story shows numerous instances of identity construction. Nancy understands her place within the state structure as an IDP; she also discussed her selfunderstanding relating to her place of origin and her role as a mother; and the exclusion that she recognizes when she states that the people in Bogotá are cold.

Notions of social construction mentioned above are contradictory to and come in conflict with fixed notions of identifications useful in identity politics, especially when a united and cohesive group fights symbolic violence in the form of political categorization and discrimination by the state. Identity politics is the construction of a unified alliance by the marginalized to articulate their oppression in terms of their own experience (Hale 1997).

Identity politics play a role in Bogotá among IDPs. IDPs perform groupspecific projects where they solve problems in urban life after resettlement. Through identity politics, people make sense of their practices, the results of those practices, and differences with others (Brubaker and Cooper 2000). People utilize identity politics to persuade others "like them" to fight for a specific cause. Culturally specific projects and persuasion for a common cause take place in Colombia when IDPs march together to claim better treatment from the government or stage months-long takeovers

16 "Mejor morir en mi tierra que vivir en una ciudad donde nadie nos quiere." (Text above translated by author). 
of public spaces to demand better housing. I analyze two examples of collective social action of this type later in this chapter.

In the prior chapter, I discussed the way in which the 1991 Constitution adopted a notion of cultural pluralism. Categories key to the understanding of cultural pluralism "involved issues as varied as collective memory, environment, culture, rights, the state, and production...[T]hey concerned the politicization of difference and the construction of a new political subject" (Escobar 2007:249). In the 1990s, numerous actors formed race-based identities of black communities for political reasons in Colombia. These formations came about by both the "flexing power" of the state and the enacting agency of the "subaltern" to create collective action (Escobar 2007). Similarly, IDPs today undertake a dialectical discussion with narratives created about them to form alternative identities for political reasons. Just as "black communities" became a new identity that had to be defined by multiple actors for different political reasons, IDP identity formations also take place through the "flexing power" of the state, the non-displaced public, NGOs, and the "subaltern" IDPs themselves.

In this chapter, I will discuss the formation of internally displaced persons' identities in the city of Bogotá. Many people interviewed self-identified (Brubaker and Cooper 2000:18) with their place of origin and the social activities that they performed before fleeing their land. IDPs interviewed saw themselves as belonging to a specific place or department. They found the city a foreign place where they had to adopt new strategies to survive. IDPs faced discrimination in Bogotá from both the 
public and the state. In this chapter, I examine identity narratives, exploring how IDPs and non-displaced populations see themselves and each other.

I look specifically at "invasion" narratives, which are generic stories told about IDPs and other shanty-town residents. These narratives have formed a part of the larger discourse in the city of Bogotá, where the city's residents craft their own identity in contrast to negative accounts about IDPs. In this chapter, I will also discuss how the IDPs I spoke with defined themselves in relation to the city, the government, the non-displaced public, and the negative discourses about themselves.

Identification and Categorization: 'Othering' and State Identity Formations

Many urban citizens in Colombia retell the common narrative of invasiones (invasions). "Invasions" are the shanty towns that line the outskirts of major cities throughout Colombia. In these shanty towns live large numbers of people classified in the poorest segment of the population. In this area of the city, the non-displaced public stereotypes poor people in a negative light. Internally displaced individuals come more often than not to the poorest areas of the city. IDPs acquire all the negative stereotypes given to people in invasions once they resettle in such areas. Through narratives on invasions, the majority of the public assigns defining characteristics to and performs identification of the IDP other. These "invasion" descriptions erase IDP life histories and create new definitions of IDPs that do not fit into their lived realities. 'Othering' engenders symbolic violence (Rojas 2005).

The UAO offices at Bosa-Kennedy and Ciudad Bolivar-Usme, where I did my fieldwork, are located in some of the least desirable parts of Bogotá. These 
marginalized shanty towns are home to newly resettled IDPs escaping violence. The public discourse characterizes the 'invasion' communities negatively. Not knowing what shantytown dwellers have gone through, especially those who have been displaced, non-displaced individuals often identify slum-dwellers as drug dealers or as criminals to be feared and despised. This perception motivated the warnings I received from friends and acquaintances every time I visited the UAO offices.

Brubaker and Cooper (2000) offer a disentanglement of the various concepts now encompassed by the term "identity." They present three set of terms that I find useful and they provide the analytic framework for this chapter. The first term, "identification," examines the processes of creating identity where in an agent, or agents, is doing the identifying, though the identifier(s) may or may not be known (Brubaker and Cooper 2000:14). Identifying the self, or the other, creates defining characteristics in everyday life and in any social context. Modes of identification have assumed a categorical quality when describing IDPs in Bogotá (Brubaker and Cooper 2000:15). An example within Colombia is the way that IDP identity descriptions by the non-displaced public suggest that IDPs are lazy and uneducated and affiliate IDPs with pre-existing negative perceptions of shantytowns. Friends and acquaintances who warned me about neighborhoods where UAOs are located, also related narratives with negative implications such as: "They are the ones selling things on the street corner at stop lights;", "they are the indigenous looking ones;" "they are the ones with their children around them asking for money with signs." The non-displaced

\footnotetext{
${ }^{17}$ Usually they are referred as ambulantes.
} 
public uses categorical qualities to describe IDPs as belonging to the poor, invasion areas of the city.

As they create negative stereotypes about IDPs, the non-displaced public and government officials erase existing cultural identities. Afro-Colombians and indigenous populations make up thirty-three and five percent of the internally displaced population respectively; however, Afro-Colombians constitute five percent and the indigenous populations only make up two percent of the people in Colombia (Bello 2006). However, when public narratives begin to assign 'othering' characteristics to ethnic minorities, cultural identities disappear from the public's mind. Instead of taking into account the cultural and linguistic diversity of the IDP population, public narratives focus on perceived realities seen in urban centers, of IDPs being lazy and criminal. Brubaker and Cooper argue that "identification" can be pervasive and influential, and may not have a distinct actor practicing it; rather, it "can be carried more or less anonymously by discourses or public narratives" (2000:16). The state and the non-displaced public utilize narratives to form the negative IDP identity that displaced people carry in Bogotá. 'Othering' is taking precedent, where the state and the public mask past and lived experiences. Despite the actual heterogeneity of the population, homogeneity characterizes discourses about IDPs. Categorizing Afro-Colombians and indigenous populations with negative stereotypes of IDPs and poor populations is not so hard, because of already existing ethnic discrimination in the country. 
The modern state has become a powerful identifier and achieves symbolic force through imposing state categories. In Colombia, the state performs strong identification through fundamentalist ideas. In chapter 3, I presented the current president's policy of Democratic Security (Seguridad Democrática). In such discourse, the state identifies who is a "compatriot" and who is not by which citizens adhere to state policy. Rojas (2005:212), a political scientist, argues that the state converts differences of the other into dangers and assigns values to others through fundamentalist ideas of security, nation, or God. For example, the state defines negatively those individuals who do not defend the national territory under the guise of Democratic Security. Furthermore, the state creates political exclusion by silencing voices deemed dangerous. The state must recognize others' legitimate identities so political participation may occur (Rojas 2005:213). In Bogotá, IDPs have been forced to fight for political participation through social resistance. Such resistance has created new political subjects who create practices of identity that challenge public descriptions of IDPs. Displaced persons engage in identity politics and craft group solidarity around an identity of being displaced and marginalized in Bogotá. I examine two cases of resistance later in this chapter.

The Colombian state also creates identity classification for displaced individuals. To obtain IDP status, IDPs retell violent events leading to displacement to government officials. IDPs whom I interviewed hoped that functionaries would believe their experiences so the government officials add the IDP to the national registry of displaced persons. Officials at the UAO offices gather and collect stories 
and memories by recording ages, "racial" identities, town of origin, new addresses and telephone numbers, family make-up, local networks of family and friends, level of education, and past employment history. ${ }^{18}$ The state also decides and assigns IDP categorization. Such forms of identification follow Foucault's idea of disciplinary power and surveillance (Hall 1992:289). Before displacement, many individuals did not hold any government documents and were not recorded in state files. The government now tracks every aspect of IDP lives and defines them accordingly. State workers bring portable and on-the-go-national-ID-card-making machines to UAO offices. The Colombia government can now identify and administer displaced individuals who have never before held state documents. Displacement is now a governmentally defined reality, and IDPs are governable subjects (Rose 1999). Gathering and collecting information about IDPs allow the state to extend its authority over citizens.

An example of the state creating new, governable subjects is the exchange I witnessed between Nohemi and a government worker. Nohemi, an IDP displaced from the Llanos Orientales, met with a government official when she was seeking aid at an UAO office. Witnessing the exchange, I asked Nohemi if I could speak with her confidentially. Nohemi told me, and I overheard, that the official demanded that Nohemi name her tribe. A member of the Sicuani, Nohemi told me that she was

\footnotetext{
${ }^{18}$ While conducting fieldwork in the UAO offices, I saw first hand the interview process of many IDPs with state functionaries. The questions asked incite one word responses. The state worker types the response quickly and moves onto the next question. Regarding "racial" identities, in Colombia, the government has three racial categories: mestizo, black, and indigenous (Ministerio de Educación Nacional, Republica de Colombia). The functionaries type the answers in spreadsheet documents that are loaded up to a government database.
} 
hesitant to give the government worker the name because of the negative treatments that indigenous populations receive in Colombia. Continuing in our conversation, she said that the worker told her that he knew very well she was a member of an indigenous group because of her physical appearance and scoffed that indigenous people never give the name of their tribe. Nohemi shared with me that she never had a birth certificate or Colombian documents. In order to receive state aid, Nohemi relented and answered all questions so she could receive benefits as an IDP and apply for temporary documents. Needing food for her son, Nohemi told me that she had no other choice but to answer the questions. Her answers and personal information were now part of the National Registry of Displaced People.

Just as government policies and UAO official identify and marginalize IDPs, so does the non-displaced public in Bogotá. The non-displaced public, in an everyday and social context, identify IDPs as money-hungry, uneducated, ungrateful, and amoral "invaders." Gracia, the non-displaced business owner from the previous chapter, identified the IDP population as untrustworthy liars. Manuel, a non-displaced person from Bogotá who works as a baggage handler, initially identified the IDP population as lazy people living off the money the government handed out. I met Manuel through a friend. He became interested in the work I was doing, and offered his help during my time in Bogotá. Manuel became friends with Andrés Quiroga, who invited Manuel to visit the UAO office. After visiting the UAO with me and listening to the actual amount of government aid IDPs receive and the realities and hardships that IDPs face as they attempt to resettle in Bogotá, Manuel was genuinely shocked 
and saddened by the lives IDPs endure. Such stereotyped views affect IDPs adversely, derailing attempts at finding jobs, adequate housing, and education. In addition, IDPs create identification with the past employment—such as farm work—and place of origin. I explore the last two points more in depth in the following section.

Self-Understanding and Social Location: IDP Responses to 'Othering' in New Social Contexts

Having discussed identities imposed by the state and the non-displaced population through Brubaker and Cooper's (2000) first term, "identification," I now turn to the self-understandings of IDPs. Brubaker and Cooper introduce the second term "self-understanding" as way in which one senses, or understands, who one is within one's social location, and how, once these two attributes are understood, one acts (2000:18). Here, the "self" is culturally specific and formed differently by different people. Within the neighborhoods surrounding the UAO offices of CiudadBolivar and Bosa-Kennedy, people understand the discriminatory social categories placed upon them. For example, knowing the near impossibility of not becoming part of the formal economy, many displaced persons make a living in the informal economy by collecting trash to sell recyclable parts, getting paid under the table for cleaning houses, or selling merchandise on the street. IDPs self-understanding of the urban, social context they now experience allows IDPs themselves to act in socially specific ways.

Internally displaced persons form a self-understanding that contrasts with the non-displaced public's discourse. Self-understanding helps link a person to a place, a 
process that forms deep roots and lasting influence (Peteet 1995:170). Nostalgia helps people to think of the self. Narratives shared by IDPs on self-identification focused on references back to their land of origin. IDP accounts contrast with those shared by the non-displaced public in terms of jobs, culture, and place. IDPs see people in Bogotá as rude and cold, while those in rural areas of Colombia are open, hospitable, and sharing. Juan Bautista, the IDP from Cauca introduced earlier, discussed his past. He called himself a farmer. Cultivating the land in order to provide for his family is what he knows. When asked about the place where he was from (the campo, the fields, rural areas), Juan Bautista's face lit up with a smile. There, one "worked hard, and one was proud to be knowledgeable about farming." In contrast, he said that people in the city look down on such work. Juan Bautista finds dignity in being a farmer despite the fact that violence displaced him from his land and home. He stated in a bittersweet voice, "I would like to go back [to the campo]. If an opportunity arose to work and support my family doing farm work, I would take it, no matter where.” Juan Bautista sees himself as part of a culture of farmers-non-city residents-who love their livelihoods. In addition, he has an ongoing dialogue with the city discourse and counters ideas that those in the fields are backwards or uneducated-as some nondisplaced public narratives have shown. He proudly stated that "Working the land was my education."

Another point of self-understanding deals with the way IDPs contrast people in the city to those who live in their former homes. This contrast allows a creation of moral superiority for the self despite discrimination faced after resettlement. IDP- 
narratives show a dichotomy between city and rural living: the cold weather of Bogotá versus the nice climate of their land; the closed attitude of city dwellers versus the open and sharing attitude of the people of their home town; the possibility to sustain oneself by working the land versus the humiliation of begging for work or food in the city. IDPs see Bogotá residents as withdrawn, cold, rude, and uncaring. In that sense, the non-displaced, urban public is contrasted to the farmers who worked together, the neighbors who provided food, and the people in the campo who were open, smiling, and sharing. Gilberto, an Afro-Colombian IDP, identified himself in that dialectic. I met Gilberto in a waiting area at the Ciudad Bolivar-Usme UAO office. He stated that in the campo "one does what one wants, and finds food wherever; whether it is from the neighbors or the land. In the city, that is not the case." For many displaced individuals, having a connection to their land of origin allows them to create identity in the face of discriminatory social practices by non-displaced city dwellers.

An understanding of one's social location affects not just the way people attempt to find jobs, but also the way IDPs act in every aspect of their lives at the margins of society. Eduardo, a 31-year old IDP from the department of Sucre, compared the way he must act in the city and in the campo. I met Eduardo at FAMIG (Fundación de Atención al Migrante, Foundation of Attention to the Migrant). He says that in the campo one can do anything at any time. In addition, people where he is from would open up their homes to feed anyone in need. There, Eduardo did not have to worry about having a job or having enough money to eat. However, Eduardo stated that in the city, you must have money. Without money, one cannot eat. The 
only way to get money is to work, and Eduardo says that no one in the city will help him get a job because of his situation as a displaced person. Now, he must scavenge the streets for things to collect and sell for money. He finds walking the streets shameful and says that the glares he receives put him down. Social institutions that create oppression through structural violence (Farmer 2004) affect IDPs chances at acquiring job opportunities.

Another example of IDPs contrasting the place of origin and the new urban setting is Nancy's narrative. Nancy, presented above, has been trying to integrate into the city of Bogotá. I met Nancy on a very cold Thursday at the UAO office as she waited for the emergency funds, crying. Her biggest complaint about the city was its cold people and weather. She talked about the cold water in the morning. Bogotás high altitude makes the city very cold. In the morning, temperatures can dip into the low 40s Fahrenheit (4-9 degrees Celsius). Despite the temperature and lack of hot water, Nancy always took a shower because that is what her mother taught her to do. She found the people in Bogotá the same as its weather. Through a very poetic analysis, her narrative reveals that non-displaced people did not care about the displaced; the city's citizens were cold and inhospitable. Nancy said, "It is better to die in one's land than to live in a place where nobody wants us." 19 Reversing the popular discourse created by the non-displaced public, Nancy argues people from Bogotá are bad, while people from her town are good. Similarly, Lourdes, displaced twice, is very familiar with the way that non-displaced residents of Bogotá treat IDPs.

19 "Mejor morir en mi tierra que vivir en una ciudad donde nadie nos quiere." (Text above translated by author). 
Interviewing Lourdes at one of her friend's house, she said, "Nobody helps you here in the city," when referring to the non-displaced public. In this statement, Lourdes also referred to job opportunities; many business owners in Bogotá do not give opportunities to IDPs.

People form identity within a given social location. IDPs accommodate existing negative discourse about themselves in order to find jobs more easily. Adriana, a 32-year old IDP, single parent with four children, understands herself in relation to other city residents. She knows that in order to survive and provide for her children, her best strategy is to hide her displacement. Adriana, referring to job opportunities, stated that "When one says that one is displaced, no one helps you." People in the city are not willing to take "risks" on IDPs as potential employees because employers believe that IDPs are uneducated or untrustworthy. Adriana says that "It is best not to say anything." Adriana understands the public discourse and stigma associated with IDPs. She believes that it is in her best interest to keep this identity hidden.

IDPs self-understanding changes from the pressures of the economic realities of who is excluded from the formal economy and who can best find employment in the informal economy. Borda Carulla (2009:42) argues that men displaced due to violence report a sense of lost dignity and helplessness when they arrive to urban centers. Though it is difficult for displaced men and women to find jobs, women find it much easier to integrate into the informal economy because of their experience in domestic work. Internally displaced individuals who come from rural areas, where 
gender roles dictate that the man works outside the home while the woman of the house stays home working on domestic tasks, experience gender-role reversal in Bogotá. Unemployment and a lack of access to networks that may help with employment affect women and men differently. Women I interviewed told me that their husband left the city in search of jobs. They left Bogotá to do farming jobsjobs that men had more experience with - to have something to provide for the family.

Women commonly reported becoming the head of household due to the loss of their husbands or male partners, either through death during displacement or abandonment after resettling. That is, women reported having to integrate themselves into the work force-formal or informal economy-because no other individual in the family could take on a job. Though finding a job was nearly impossible, women stated that they were out in the street talking to businesses all day, seeking janitorial or cooking jobs. Men, however, looked for more physical labor. This type of work is hard to come by, and men often attempt to find jobs outside the city. Often, children stay home with a neighbor, landlord, or the oldest child as a caretaker.

\section{Commonality, Connectedness, and Groupness: Group Identity and Identity Politics}

IDPs throughout urban centers in Colombia create a shared commonality and connectedness of personal experiences. These types of experiences create group identities that contrast with the first two terms concepts of state-identification and selfunderstanding discussed above. Brubaker and Cooper (2000:19) introduce the third set of terms "commonality and connectedness" to analyze concepts of strong-bound and felt closeness within groups of people which lead to "groupness." These terms 
create an "emotionally laden sense of belonging to a distinctive, bounded group, involving both a felt solidarity or oneness with fellow group members and a felt difference from or even antipathy to specified outsiders" (Brubaker and Cooper 2000:19). Commonality refers to the notion that shared attributes or qualities exist within people. Connectedness represents the social or relational webs, links, and bonds that unite individuals. Together, commonality and connectedness form groupness - the idea of "belonging to a distinctive, bounded, solidary group" (Brubaker and Cooper 2000:20). "[A] feeling of belonging together" (Brubaker and Cooper 2000:20) enhances the terms commonality and connectedness. For example, IDPs in Bogotá feel a sense of togetherness with other IDPs due to their social commonalities of living at the margins of cities; of living through violence and abandoning their lands and homes; or of being discriminated against. Groupness among IDPs has created strong collective action. IDPs have a shared commonality of living through violence and a connection of navigating the same bureaucratic steps and of living at the margins of a city. They are utilizing the memories of violence from the past and creating projects for sustainable action in the future (Rojas 2005). Social movements contest the attempts by the state and the non-displaced public to monopolize identification.

Many people who have been displaced form social groups to make changes in their lives. The IDP group of Afro-Colombians in Bogotá, led by Martha, is an example of what common qualities and connections accomplish in relation to group formations. The IDP group of Afro-Colombians formed in 2004 to help displaced 
Afro-Colombians in neighborhoods around Bogotá. Martha is a vocal leader who fights for the rights of the members in her group. I first met her at a meeting held in a UAO conference room of the Bogotá bus terminal. The UAO at the bus terminal had invited me to participate in a focus group to discuss key issues that might help IDPs in Bogotá who face obstacles in access to education. This focus group generated key issues that were brought up later in a June 2009 conference with the rest of UAO offices across Bogotá. Martha was the only displaced person at the meeting conference room at the bus terminal and was vocal as to what points they needed to get across.

Though the group celebrated its Afro-Colombian background, it did not limit its goals for better living conditions solely for displaced Afro-Colombians. Narratives suggest that regional/ racial identity remains powerful within the IDP population. IDPs' identity occupies an intersection of different sorts of stigma: racial (AfroColombian or indigenous), poverty, displacement, single parenthood, and so on. IDPs situate themselves in multiple subject positions relating to identity within Bogotá. The group fought for rights hand-in-hand with other IDPs who shared common attributes (Brubaker and Cooper 2000). For example, Martha often met with IDPs in SENA (Servicio Nacional de Aprendizaje, National Service of Education) and their instructors to see that services guaranteed in Law 387 had been met. The group also joined forces with functionaries that believed in their cause. Martha and her group's actions exhibit notions of commonality bringing together individuals who face discrimination from the state everyday, resettle with their families in the new urban 
setting, and scavenge the city for any work. Martha's way of creating rapport with anyone she met helped her achieve many accomplishments in the last five years. In addition, Martha's group also demonstrated with pride their Afro-Colombian identity. During the conference with UAO and government functionaries, a heated debate arose concerning why nothing ever gets done. In a circle of about thirty people, Martha started yelling, grabbing the attention of everyone around her. After she made her point on the government's ineptitude to solve problems and suggested a new policy the government should adopt, she realized that her voice had drowned out others. Not missing a step she yelled even louder, "What did you all expect? I am costeña." Everyone laughed. Costeño/a is someone who is from the coast, and usually of AfroColombian descent. People from this region are characterized by the rest of the country as being loud and aggressive. Here, Martha appropriated this sentiment in a positive light, emphasizing regional, rather than IDP, identity.

It is important to note here that internally displaced persons take political action against marginalization. For example, IDPs often protest against their inferior living conditions in Bogotá. State identification does not hold total control in defining IDP identity. Through marches, or takeovers of government offices or public parks, IDPs demonstrate their political agency and in the process shape their own political identity. In chapter 5, I will discuss in depth the practices of social movements formed by IDPs living in Bogotá. 


\section{Conclusion}

I discussed in this chapter different identity discourses present in the city of Bogotá relating to internally displaced persons. I have used Brubaker and Cooper's three-way theoretical classification to disentangle some of the issues that arise when analyzing IDP identity in Bogotá. Narratives highlighted by the non-displaced public deployed negative ideas of IDPs and categorize IDPs as burdensome through "identification and categorization" of the other (Brubaker and Cooper 2000). People in the city denied IDPs the right to work and to sustain themselves. Displacement and unemployment created a belief in the non-displaced public that IDPs are only interested in government aid and not concerned with finding a job.

Displaced people separated their "core" identity from who they are in city life. The "self-understanding" discourse shared by IDPs contrasted with the identification and categorization formed by the state and the non-displaced public (Brubaker and Cooper 2000). Where the non-displaced public identified the IDP population with negative characteristics, IDPs turned those ideas and highlighted the positive aspects of their place of origin and background. IDPs identified themselves with the campo and an idea of shared, open community of family and neighbors. Their displacement has taken them away not only from their homes, but also from their livelihoods. In addition, aware of their new social context, some IDPs accommodate the dominant discourse and must hide their displaced identity in order to get work.

People in a situation of displacement come together because of their shared histories in experiencing violence, in living in shantytowns, and in visiting UAO 
offices. In the face of symbolic and structural violence, group identity among IDPs is growing, and new avenues of social action are opening up. IDP-identified groups are coming together, drawn by their commonalities, feelings of belonging, and shared past experiences (Brubaker and Cooper 2000). They are also acting for future change in the political arena. IDP group identity in Bogotá is creating new spaces to contest government treatment. The IDP voice is growing, though marginalization is still prominent. IDPs create "groupness" through social action, as well as through strategies of survival (Brubaker and Cooper 2000). It is in the context of where and when IDPs act that we see IDP identity (Borda Carulla 2007). Groupness forms through connectedness, commonalities, and feelings of belonging. In Colombia today, internally displaced persons perform practices through political voice, creating the strong sense of groupness needed for social movements. I explore resistance and IDP social movements further in the following chapter. 


\section{Chapter 5-Social Conditions: Resistance and Acceptance}

Collective actions by the displaced people, such as takeovers of public offices, marches, and other ways of making visible their demand for recognition, have taken place in various regions of the country, and on occasion have fused with other political and social causes (Segura Escobar 2000:122).

At government conferences and meetings, IDPs invited to contribute to policy concerning their plight took advantage of the invitation and freely spoke about ways in which government officials could assist their resettlement process. These conferences and meetings were largely symbolic in meaning. However, I witnessed that IDPs took over discussion groups, talked beyond their allotted time to the assembly of government officials, and harshly criticized government functionaries directly at these meetings. IDPs, characterized as helpless victims, took advantage of this symbolic setting to make statements about their own issues, issues facing IDPs as a whole, and their wish to change their situation.

Even though displaced individuals contested state representation in some contexts, in other contexts they continued to reproduce known structures of discrimination, accommodating existing power structures and discriminatory practices. At UAO offices, I witnessed displaced individuals continuing to interact with state officials despite known discriminatory practices. In order to receive the state aid, IDPs continued to enact subordination. IDPs choose strategically whether to resist or accommodate to the social structures that surround them.

In Colombia, victimization discourses presume that displaced persons hold no motivations, intentions, or projects after violent displacement. In this chapter, I will 
argue how such discourses of victimization obscure true agency. For example, social scientist Merteens (2006:441) claims IDPs no longer hold the intentionality to act as they once did before forced displacement. Internally displaced persons are also seen as victims of history and as individuals who do not hold any power in shaping social processes (Bello 2006:385). In this chapter, I draw out several theoretical strands to conceptualize the agency of IDPs. Additionally, exploring IDPs' agency within the new, urban environment will show how IDPs themselves perform action "pointed toward some purpose" (Ortner 2006:134; emphasis in original), action that the victimization discourse hides. IDPs - through collective and individual actionsaccomplished several positive goals, but other negative aspects of urban resettlement continue to exist. Many social movements (e.g. NGOs that help the IDPs) are run and staffed by non-displaced people, and some of the UAO officials are sympathetic to the IDP cause. Despite a dominant discriminatory discourse in Colombian society about IDPs, there are also alternative currents. There is a range of views in civil society about IDPs. NGOs create avenues where IDPs can settle into urban centers more easily, and numbers of non-displaced public help fight for IDP causes.

\section{Agency and Structures}

In this section, I draw on theoretical perspectives to present how actors (IDPs) demonstrate agency, the ability to act. Actions such as visits to UAO offices, meetings with government workers, marches, and takeovers of public and government spaces are examples of IDP agency. 
Through agency, the actor performs (routine or intentional) practices of reproduction or transformation. Sherry Ortner (2006) suggests that agency has two aspects: one aspect is the "agency of projects," in which actors intentionally pursue culturally defined projects: while the other aspect is the "agency of power," in which actors gain power over others through relations of social inequality, asymmetry, and force (Ortner 2006:139). Actors need power over others to achieve their projects. The state and the non-displaced public create narratives and discourses which categorize IDPs as criminals, and, therefore, undeserving of government handouts. This discriminatory tactic supports the government's strategy to save money and direct public attention away from the violence going on in Colombia's rural areas. Doing so, the government claims that it has not committed any human rights violations, and is not responsible for IDP claims.

However, IDPs undermine the government's agency of power over them by continuing to draw strategic attention to issues of displacement and by appropriating and transforming marginalization and 'othering' narratives. Placed and categorized, displaced persons appropriate negative stereotyping and act from that position. IDPs shape their projects in culturally specific ways. In Bogotá in 2008 and 2009, IDP actions took form through takeovers, sit-ins, and marches. At the Bosa-Kennedy UAO office, displaced individuals took over the office and created a living space in which they were able to contest negative treatment. Through marches-strategically staged at nationally significant dates and places-IDPs voiced their marginalization publicly. I present these examples in more detail below. 
Individuals act within cultural and historical structures. The way one acts is contingent upon cultural and historical products, and "every culture, every subculture, every historical moment, constructs its own forms of agency" (Ortner 2006:57). As shown earlier, since the late 1990s, laws concerning IDPs have changed dramatically. Because of a progressive Constitutional Court in place in Colombia since 1997, despite continuing discriminatory discourses, internally displaced individuals now face a friendlier political environment than they did a decade earlier. Laws have changed to benefit IDPs when they attempt to claim new residences in resettlement places, or when they seek respect from government functionaries at different offices. Where "invisibility and silence reigned" in the early 1990s, a wide range of "legal, institutional, economic, professional, and organizational resources" (Segura Escobar 2000:108) exist today.

Agency takes different forms in different contexts. Agency is both resistance to and "complicity with, accommodation to, or reinforcement of the status quo" (Ahearn 2000:13). IDP agency manifests as resistance to political marginalization, as mentioned above. But, it also creates forms of reproduction "that aim for continuity and stability" (Lynch 2007:36). For example, I observed that IDPs work within the existing political system, using existing stereotypes of themselves to get funds from the government. Actions of reproduction form one way in which IDPs can receive state aid to pay rent, to feed their families, and to have access to education and healthcare. In these ways, IDPs reproduce known strategies, choosing to accommodate to the existing system rather than resist it. 
Discussions on agency correspond to theoretical frameworks of structures. Actors rely on structures when performing (routine or intentional) practices. Following Sewell, I understand structures as "mutually sustaining cultural schemas and sets of resources that empower and constrain social action and tend to be reproduced by that action" (Sewell 2005:151; emphasis added). Schemas are general procedures that people apply to a variety of social interactions (e.g., how someone who declares as a displaced person acts in front of government officials recording her/his story, or how IDPs act at collective moments of resistance-for example, marches or takeovers). Individuals are knowledgeable of these cultural procedures. All individuals have resources, both nonhuman—objects that "enhance or maintain power"-and human-"physical strength, dexterity, knowledge, and emotional commitment that enhance or maintain power" (Sewell 2005:133). An example of resources, in the case of IDPs, may be an emotional sense of solidarity that enhances power to resist and challenge discrimination. IDPs performed resistance through solidarity when they shut down the Bosa-Kennedy UAO office. When IDPs achieve goals from takeovers, they illustrate their empowerment through their success.

Structures empower and constrain social action; reciprocally, social action ultimately forms structures. Sewell argues that structures must be seen as dual; "that schemas are the effects of resources, just as resources are the effects of schemas" (Sewell 1992:13). IDPs understand that at UAO offices workers do not regard them as equals. Government workers discriminate against IDPs, despite laws passed in the last fifteen years. IDPs are aware of such discrimination. The government functionary 
holds a certain position, and in order to receive sought after aid, a displaced individual must "act accordingly" within this schema. "Acting accordingly" at UAO offices, IDPs cannot publicly complain about harsh treatments of functionaries, cannot ignore questions demanded by government officials, and cannot receive state aid without becoming a state subject. Similarly, displacement from one's home or land reduces IDPs' resources (whether the loss of social and kinship networks or the disappearance of monetary holdings). Diminished resources affect how a displaced person might interact with the non-displaced public or government workers. Structures constrain social action of IDPs through the general, UAO office procedures (schemas), which are the effects of (diminished) resources.

In summary, I understand agency as culturally constructed, laden with power differences, intentionally pointed toward cultural specific goals and projects, and enabled and hindered by structures. Depending on an individual's social location (e.g., whether someone is internally displaced or is a government worker), an individual's knowledge of schemas and access to resources will differ (Sewell 2005:145). Therefore, practices of resistance against, transformations of, reproductions of, complicity to, or accommodation to structures will bring about different possibilities.

In the rest of this chapter, I discuss individual agency as reproduction (accommodation) and transformation (resistance). IDPs reproduce power structures at UAO offices as they know such action guarantees government funds. IDPs practice resistance when they perform actions that make them visible to society, instead of 
staying invisible. Power struggles affect IDPs actions. Finally, I present a discussion of collective agency and social movements. Marches and takeovers throughout Bogotá are a powerful tool for displaced individuals.

\section{Individual Agency: Reproductions and Transformations}

In the hours that I spent observing interactions at UAO offices, I noted the many ways that interactions between displaced individuals and government functionaries reproduce social structures. Displaced people acted subordinate to receive government aid. IDPs followed a known social script. People coming to UAO offices seeking aid knew that they had to begin waiting in line at early hours of the morning. In an interview, Jose, displaced from Cundinamarca by the guerrillas, shared the daily routine that he went through when he came to the UAO. When he made a visit to a government office, he woke up at three in the morning, hopped on the first bus of the day, and made his way to an UAO office so that he could start standing in line no later than five in the morning. More often than not, the small amounts of money he scraped up for the trek only covered enough for the round trip on bus. Like many, Jose skipped breakfast and lunch in hopes that a government worker met with him; waited outside of government buildings until functionaries decide to help him; and endured hunger and thirst until someone spoke with him. Jose's resources are limited when Jose—tired, sleepy, and hungry—interacted with the schemas of the UAO office, which makes Jose accommodate to and reproduce the known schemas.

My impression from observing interactions between IDPs and government workers at the UAO offices is that IDPs do not discuss or share these daily tolls of 
hardship with government workers. Sitting in office meetings, with a government worker and a displaced person, I heard cordial conversations transpire, and both people used formal language. This interaction suggests how power relations work between subordinates and superiors. Scott (1992:56) calls this type of interaction "public transcript:" the public interaction between subordinates and superiors that makes both parties misrepresent the real power relations. Displaced individuals must not speak of any injustices (experienced on the street or at the UAO office) if they have not been asked. The interactions at offices between the two parties follow procedures. However, when I spoke to displaced individuals in private after these cordial meetings, they expressed other sentiments, or "hidden transcripts," which Scott (1992:58) says are the discourses told behind the backs of power holders. IDPs said that acting subordinate or following procedures would not upset anyone who holds power over whether IDPs receive government aid or not. In a private interview, Nancy, introduced in the previous chapter, angrily stated that she knew government workers talk down to her. She heard discrimination in their voices and felt it in their glares. She strategized that allowing the interactions at the UAO to continue was her best option. She stated, "You think he [the functionary she spoke to on that day] is capable of offering me a glass of water? I do not tell him that I have waited outside since five in the morning [it was one in the afternoon when she told me this], but he knows it. All of them [referring to the other functionaries] know it. But I must keep quiet." This "hidden transcript" allowed her to vent, as well as define, clarify, interpret, and illustrate her goals within the UAO office in ways that "confirm, 
contradict, or inflect what appears in the public transcript" (Scott 1992:58). Structures in this context, which constrain IDP social action, define the schemas that the government official and a displaced person play and limit IDPs' resources to enact change. However, displaced individuals are aware of the schemas and utilize their limited resources to acquire funds. IDPs accommodate to the power-projects of the officials in order to accomplish their own projects of getting funds.

However, within UAO offices, IDPs form solidarity and endure harsh treatment by becoming resources for each other, based on their shared community of interests. For example, single mothers help each other at waiting areas, in lines, and outside by keeping an eye on each other's children. When called to meet with a functionary, a mother will leave her child in the care of another mother. Though both mothers may have just met on that day, the mothers support each other, making the process of declaring or seeking funds easier.

In addition, I witnessed IDPs standing up for one another several times. For example, in one situation where a government official had talked down to one displaced person or had insulted her or him, other displaced persons in the area would come to support the person being belittled. One day, I sat at the waiting area of the Bosa-Kennedy office, when I heard a loud commotion. A group of three or four IDPs were circling Andrés Quiroga, a government worker, demanding that he apologize for the rude treatment of someone who had come in earlier. As I walked toward the commotion, I heard people accusing Andrés of maltreating a man's wife. After vain attempts at saying he had not done anything wrong, Andrés apologized in front of 
many IDPs for his actions. Though Andrés did not retaliate toward other IDPs he saw, he did vent to me his view on how IDPs twist and mischaracterize his work. In this case, Andrés had to accommodate to a public-IDP transcript, and vent the frustration in a hidden transcript to me in private.

\section{Effects of Power on IDPs' Schemas and Resources}

As discussed in the instances of accommodation above, IDPs perform a "routinization of keeping quiet" to guarantee security in Bogotá and UAO offices. This same pattern also takes place if IDPs believe that police or military personnel facilitate violence performed by certain armed actors; not reporting violent acts becomes a safer strategy. In my fieldwork, I learned that a "routinization of othering" creates interesting responses from internally displaced persons. By "routinization of othering," I mean the manner in which the non-displaced public's discourse of symbolic violence has become habitual, and how IDPs accommodate to this discourse without challenging or trying to change it. Displaced individuals now act in structures in which social procedures define them as vagrants, criminals, and lazy and untrustworthy people.

I argue that the difficulties described in the prior sentence have prompted IDPs to form new social movements within Bogotá. Asymmetrical power has molded IDP identity, which in turn, the IDP population has appropriated to enact change. As Marx (1967) observed, struggles for the same cause make people aware of social solidarity with others who are similarly disadvantaged. The effects of power have not just created "hidden transcripts" in which individuals like Nancy complain that 
government workers attempt to dominate them. Struggles of power have also strengthened solidarity between IDPs in Bogotá. Assigned to a social location within the urban center, displaced individuals perform practices corresponding to how the non-displaced public defines them. By appropriating beliefs that the IDP population is vagrant or indigent, internally displaced persons take over public spaces to create living areas and to manifest change. IDPs also perform marches that temporarily takeover public spaces to voice maltreatments.

\section{Events and Collective Agency: Marches}

Throughout my time in Colombia, internally displaced persons held several marches a month. Marches were used as public means of voicing concern in respect to their conditions in the city. Peaceful in nature, the marches nevertheless garnered negative feedback from non-displaced public. Felipe, a manager of a student residence in Bogotá, questioned the motives behind a march held in August of 2009. He believed that such actions were only performed to garner attention and argued that such actions only disrupted the daily routine of "Bogotanos" who were busy making a living for their families. Therefore, Felipe performed symbolic violence by categorizing IDPs as non-Bogotanos, implying that unemployed displaced individuals are bothering people who work. Felipe feels that he must contest IDPs' marches by reasserting stereotypes that IDPs are challenging in the marches themselves.

I argue that the marches were indeed intended to do more than disrupt routines. These marches were performed at specific times that carried symbolic meaning. For example, on Friday, July 17, 2009, the CND (Coordinación Nacional de Desplazados, 
National Coordination of Displaced People) planned marches throughout the principal receptor cities of IDPs in Colombia. In Bogotá thousands of displaced individuals from all over the country, and people sympathetic to their cause, marched through the city's center. In Medellín, over 1,500 people marched the streets. Marches took place three days before July 20, Colombia's Independence Day, starting on the Friday before many left on vacation for the three day weekend, and, thus, maximized visibility as Felipe noted above.

Counter to Felipe's suggestion that IDPs where just disturbing people's travel, marches formed a counter discourse to the state and non-displaced public narrative about displacement. The demands voiced by the marchers included: the development of a strategy to promote human rights and International Humanitarian Law (IHL); a political and negotiated resolution to the armed conflict in the country (a major cause of displacement); the right to truth reconciliation, justice, reparation to violent events, and promises by the government that such events will not occur again; the recognition by the Colombian state of actual displacement figures put forth by non-governmental organizations; the implementation of agile and responsive legal mechanisms that respond to the reality of the loss of lands and territories by ethnic and multicultural societies and to the economic rights of those properties and assets; and the guarantee to displaced individual of a safe return to the place of origin where displacement occurred (Prensa PCC 2009). The marches symbolically demonstrated that IDPs deserve all the social and political rights of Colombian citizens. Three days before a 
significant national date, the participants of the marches integrated themselves into the social and political arena of Colombia.

A march I attended was held during the Week of the Migrant (Semana del Migrante), September 13-21, 2009. This week-long event was sponsored by several universities in Bogotá and the Catholic Church. The event held conferences and seminars that attempted to solve some of the problems that IDPs faced in Bogotá. The name was chosen because it was believed to represent the cultural diversity of people who are displaced better than the often used term desplazadola (displaced person). Several hundred people attended the march, as it proceeded through the streets of Usme (Figure 5.1)—one of Bogotá poorest localities located in the south of the city. The march, sponsored by the Catholic Church, lasted 5 hours and stopped traffic on several streets. The march's objectives were to show respect and solidarity for displaced individuals: help them achieve their basic needs, achieve personal security, and provide help to those in dire need. 


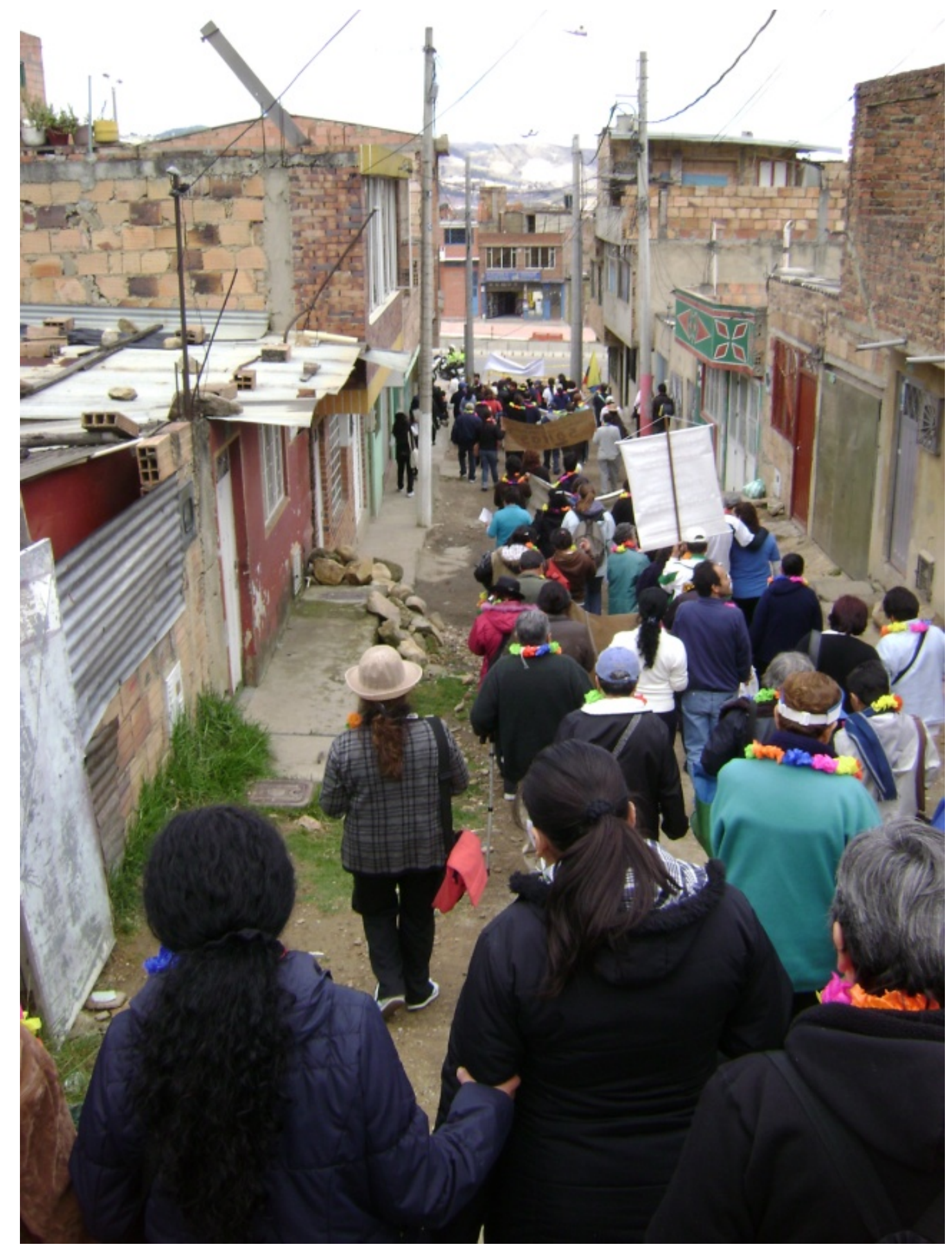

Figure 5.1. March in the streets of the locality of Usme during Week of the Migrant, September 13-21, 2009 (Photograph by Juan Esteban Zea). 


\section{Events and Collective Agency: Takeovers}

Another important form of social and collective action that reveals IDP agency is government office takeovers (tomas). Paola, a government worker who was transferred from the Bosa-Kennedy UAO to Ciudad Bolivar-Usme UAO, told me that in February 2009, several IDP-leaders gathered to discuss the way in which the IDP population had been treated by government workers in the Bosa-Kennedy UAO office. IDP-leaders also discussed ways in which they could receive better housing from the government. Paola, indifferent about the IDPs' cause but slightly irked about a longer commute to the new office, shared with me the details of the event. IDPs wanted to go into the Bosa-Kennedy UAO office with several people and stay. At first, the takeover started in the waiting area. However, as more people began staying, people made beds throughout the building and into the street. Displaced individuals did not abandon the office or the street directly in front of the office for several months. Many set up tents and make-shift kitchens. For three months the movement grew, and by May 2009 the office had shut down because government workers could not perform their jobs and got sick due to the unsanitary conditions. Despite the closure of the office, people continued to live there. Between the months of May and September 2009, while the office was closed, displaced individuals created a living space in the office and street directly outside the office, where government workers had once decided who deserved government funds needed to pay for housing.

Negotiations with the government regarding the return of the office continued for nearly half a year. In September 2009, as part of the settlement, city officials 
relocated displaced people to lands or to rooms in albergues (hostels) as the law called for. For others, the city government provided adequate housing and monthly payments that had been delayed for several months. Demonstrating that their living conditions were dire, individuals took action. Uniting for a common cause, the individuals who took over this UAO office utilized (human) resources available: solidarity, a commitment to better their lot, and knowledge to act appropriately in a symbolically evocative schema. ${ }^{20}$

Another example of collective agency by IDPs was the takeover of a public park, which produced positive change for IDPs. A week prior to my arrival in Bogotá in April 2009, nearly one thousand displaced individuals took over Parque Tercer Milenio (Third Millennium Park). In 1998, the city of Bogotá had begun planning to build the park. For the construction of Third Millennium Park, the city bulldozed hundreds of homes, and people who had lived in that neighborhood moved to areas like Ciudad Bolivar in the south of Bogotá. The newly built park is a short walk southwest from the main city plaza, Plaza Bolivar.

With the park, the city wanted to construct a space that would erase those “negative elements." The city of Bogotá's Secretary of Culture, Recreation, and Sport states that there is a positive feeling in the air and that:

There is no more street of el Cartucho [area of the city characterized negatively because of drug dealing, prostitution, and crime], and it is

\footnotetext{
${ }^{20}$ After the takeover of the Bosa-Kennedy UAO office, people received funds to find adequate housing or relocated through government funds to new lands outside of the city. I was not able to hold interviews with people after the takeover to see whether the takeover had helped or not. A good project for future research would be to ask what people did with the money or how they enjoy living in their homes and land.
} 
hard to believe when you sit on the gardens, on the grass, or in any of the benches that are in Tercer Milenio Park, which has now replaced the site that a few months ago was a whole of misery and sadness, where hundreds of men, and children, in the midst of piles of trash and 'cadavers of things,' disappeared, thrown on the floor or propped up against faceless walls. The Tercer Milenio Park is now a reality and, most important of all, a happy reality. ${ }^{21}$ (Izquierdo 2005)

The IDP-takeover of the park began as a frustration over lack of respect and no foreseeable, concrete resolutions to IDP problems. Displaced individuals began to set up tents on park grounds. Drawing on commonly circulating discourse about IDPs, media outlets described the takeover of Third Millennium Park as an "invasion" during the four-month takeover. ${ }^{22}$ The takeover took place because numerous promises by the city and state government had not materialized. By the end of the four months, two thousand displaced people, who camped and took over the park, were demanding better living conditions in Bogotá. The toma (takeover) at the park challenged rhetoric about the positive steps claimed by the state and forced the city to recognize rights that IDPs deserved.

The timing of the park takeover was also significant. The Royal Family of Spain came to Bogotá for a visit before the Fifth International Congress on Victims of Terrorism held in Medellín, Colombia. During the visit in Bogotá, the royal family of Spain scheduled a tour of several neighborhoods, including a stop at Parque Tercer

\footnotetext{
21 "Ya no hay más calle del Cartucho y resulta difícil creer, al sentarse en los jardines, en los prados o en cualquiera de las bancas del parque Tercer Milenio que lo reemplazaron, que hace apenas algunos meses esto era un hoyo de miseria y tristeza donde cientos de hombres, de niños, en medio de montones de basura y 'cadáveres de cosas,' iban desapareciendo tirados en el piso y recostados contra paredes descascaradas. El parque Tercer Milenio es ya una realidad y, lo más importante, una feliz realidad" (text above translated by author).

${ }^{22}$ The article on August 2, 2009 reported by the Caracol News Agency discussing the end of the take over describes the event as an invasion.
} 
Milenio. However, the city government cancelled the visit to Parque Tercer Milenio because officials were unable to end negotiations successfully and displace IDPs from the park itself before the scheduled day for the visit. Throughout the takeover of the park grounds, several unions, social and religious organizations, and people sympathetic to the IDP cause provided food, support, and companionship. Due to the takeover, the violations of human rights perpetuated by the state on displaced individuals became visible during an important international event, held in Colombia. IDPs utilized a symbolic place and a planned international event to make their case visible to the government and non-displaced public in order to claim rights as displaced people, Colombian citizens, and human beings under human rights discourse.

\section{$\underline{\text { Conclusion }}$}

The last decade in Colombia has seen numerous rulings and new laws that have allowed IDPs to gain political power. With new legislation, IDPs participate more freely in government proceedings and plan events that create political voice for positive gains. Such events "bring about historical changes in part by transforming the very cultural categories that shape and constrain human action" (Sewell 2005:101). Laws that were nonexistent ten years ago are beginning to be enforced, and IDPs have taken advantage of the transformation of rules to assert power in receiving funds constitutionally guaranteed, finding adequate housing, and participating in conferences where policy is written. Despite the reproduction of the low social status for IDPs, they nevertheless have gained significant concessions through laws benefitting them. 
Despite displacement, IDPs have not lost their ability to act. As discussed above, IDPs show agency in both accommodating to and resisting local structures. IDPs will continue to enact culturally specific actions and will achieve gains in housing, respect from government functionaries, and employment. However, in spite of the gains accomplished, root causes of discrimination from both the non-displaced public and government institutions endure unchanged. Reproductions of and complicity to "public transcripts" within government offices by IDPs themselves allow forms of discrimination to continue. Nevertheless, IDPs know they will receive government aid. This is a goal in pursuit in which IDPs exercise their agency of projects.

Internally displaced persons continue to live in social structures that reinforce routine practices of discrimination. Those practices continue to mask past experiences and histories from individuals and their families. Masking of atrocities allows violent actions by larger structures and the state to continue. These practices continue to perpetuate power inequalities, such as limited access to job opportunities and to residential areas within Bogotá. IDPs reproduce and accommodate the existing structures where they think acceptance serves their interests better, such as gaining access to government aid, otherwise unattainable. IDPs have been able to perform intentional practices that cause transformations. Takeovers through community solidarity and collective action demonstrate that IDPs will not continue to interact with state workers and bureaucracy as the system currently exists. The cases in this chapter 
illustrate both acceptance of and resistance to the structures of power and inequality that shape IDP-urban life. 


\section{Chapter 6-Conclusion}

I hope that young people hear my story to realize how things are over here [Colombia] and that they know that people [IDPs] go forward with all their verraquera [anger, might, and will] (Daniel, May 13, 2009).

The United Nations High Commission on Refugees (UNHCR) notes that the IDP population in Colombia is one of the largest in the world. Using the government's 2009 estimate of over 3.3 million IDPs in Colombia, the IDP population of Colombia makes up nearly $13 \%$ of the world's estimated 26 million IDPs (UNHCR 2009:19). And this number underestimates the true extent of displacement; the Constitutional Court of Colombia has deemed the Colombian government's assessment well short of the reality.

The Colombian government fails to register significant numbers of individuals as displaced; rather, following the pattern of public narratives, the government regards many people who resettle in Bogotá-and other urban centers in Colombia-as homeless or poor nomads who "invade" the city. Despite progressive laws, municipalities throughout the country consider displaced persons as a nuisance, and, despite the help of NGOs and sympathetic government workers, individuals who have lived through violence continue to face hardships after they resettle in urban centers. Displaced people — many members of the non-displaced public argue and believe—are responsible for their own fates because they have aligned themselves with the drug trade or with the guerrilla movements. This argument works within a neoliberal discourse that erases evidence of structural violence and assigns blame to individuals instead. When IDPs create a contradictory discourse, some voices within the non- 
displaced public and the state claim that IDPs' actions of vocal and physical resistance make IDPs "the authors of their own disgrace, and [make] them responsible for their own defenselessness" (Segura Escobar 2000:122).

Displaced persons from Colombia are not only an internal problem. Large numbers of individuals have crossed international borders as refugees. Within Colombia, those who do not move to major cities head south to make their livelihoods as best they can, many times cultivating coca plants, while others seek asylum in Ecuador and Venezuela, where refugee areas have been established (Smith 2003:102), or in Europe and the United States. Tensions have grown between leaders of Colombia and Ecuador, as Ecuadorians suggest that Colombians have not handled the situation correctly. Joanna, who works at the Colombian Consulate in Atlanta, GA, reported that ten years ago 2 out of 10 naturalization requests to the U.S. from Colombia were based on asylum caused by displacement or threats-whether by paramilitary or guerrilla factions. She states that today, 8 out 10 asylum seekers claim displacement from political and violent threats as the reason for seeking refuge. This trend suggests that the situation in Colombia is getting worse.

Given the size of Colombia's IDP population and the magnitude of the problems that continue to drive forced displacement, a scholarly understanding of the experience of displacement is vital. My research has focused on IDP experiences after resettlement. Below, I answer and highlight the overarching argument and questions of the thesis. I focus on the contribution of this work to an understanding of how IDPs accommodate to and resist discrimination and symbolic violence, how they manipulate 
the national symbolic repertoire of significant dates and places, and how they resist marginalization through social movements.

\section{Narratives of Violence}

My first question asked: What do IDPs' narratives regarding violence tell us? The study of violence forms a significant portion of this thesis. I have argued that state, structural, and symbolic violence feed into and overlap with one another. IDPs bear the brunt of these violences and have to navigate in places where people do not necessarily see them as valued citizens. Economic policies have adversely affected the situation of many poor peasants and ethnic minorities, leading to structural violence. When people resist this form of violence, they are branded as terrorists. The state then militarizes to suppress resistance and insurgency. Due to the actions of armed groups, many individuals are forced to leave their homes-as internally displaced persons or refugees-in order to escape being assassinated, punished, fumigated, or tortured (Salcedo 2005:164). They are caught in the middle of a war between the guerrillas and a state funded by foreign aid. State forces, in alliance with paramilitary groups, help those in power apply current neoliberal policies. The large amount of funds and counter-insurgency training the U.S. provides allows the current situation of state violence to perpetuate unchecked. Once people displaced from their homes and lands resettle in urban centers, they face forms of discrimination and marginalization—quintessential forms of symbolic violence. 
Interaction with Bureaucracies and the Non-Displaced Public

In my ethnographic fieldwork, I gathered detailed data on my second overarching question, regarding the interaction between IDPs and state agencies. Displaced people went to government offices-and interacted with functionaries in order to get access to funds that the government sets aside for IDPs resettling in the city of Bogotá. My analysis has shown that people who have been displaced acquiesce to discriminatory and hierarchical systems at UAO offices in order to receive money to pay rent or gain access to education and healthcare. But in other contexts, IDPs resist symbolic violence and pressure the state to live up to its promises. This research contributes to ongoing anthropological discussion about agency, resistance, and the state.

My third main research question focused on identity formation among IDPs. In this thesis, I have suggested that individuals in the non-displaced public create and reproduce negative stereotypes and discourses of displaced individuals, defining IDPs as uneducated and unworthy of the social services that are guaranteed to them by law. In contrast, IDPs identified themselves with their prior employment-no longer practiced in Bogotá. IDPs contested negative discourses about themselves by speaking nostalgically of their former places. Through this self-understanding, IDPs also challenged the moral superiority of the urban, non-displaced residents by contrasting the cold city to the kindness and hospitality found in their rural areas of origin. 
Research done in UAO offices suggests that state officials and the nondisplaced public use othering to justify their actions. 'Othering' and stereotyping occur when the public assigns negative, essentialized identities to IDPs. My research showed that many people in the non-displaced public characterized IDPs as criminals and vagrants who were only interested in government handouts. Such symbolic violence affected the way in which IDPs integrated socioeconomically in Bogotá limiting their access to state aid and to jobs in the formal economy. Internally displaced persons internalized this sense of exclusion; they identified themselves as non-city residents and described themselves in relation to their place of origin-places in which the IDPs were productive workers with strong social networks. IDP selfunderstandings differed completely from the negative qualities that the non-displaced public assigned to IDPs. Where non-displaced people saw the IDPs as greedy criminals, displaced individuals saw city-dwellers as cold, uncaring, and cruel. IDPs formed resistance within their self-understanding of a marginalized social location (Brubaker and Cooper 2000).

\section{$\underline{\text { IDP Agency }}$}

The fourth question that directed my research was the quest to understand the ways in which IDPs exercised agency in a new, urban environment. I have argued that IDPs are both reproducing and transforming social structures within Bogotá. In UAOs, IDPs accommodate to the functionaries questions and the government's demands. In contrast, through marches and takeovers, IDPs voice their dissatisfaction with the treatment they receive. They stage their protests strategically so as to take 
advantage of symbolic national dates and times. Further, by taking over government offices, IDPs were able to create new living spaces and force the government to concede the rights and funds IDPs deserve.

Additionally, we can examine one way people react to violent events and integrate socially and economically in new social contexts. Newly created social networks formed by IDPs have come to fruition and have enacted significant and positive change in the last decade. As I argued in chapter 5, through collective actions such as marches and takeovers, IDPs have forced the state to recognize wrongdoings. Through social movements, IDPS resist current social structures. By examining narratives of displaced persons, I have shown at the local level how structural, state, and symbolic violence form, and how IDPs resist those types of violence.

\section{Future Research: Continuing Difficulties}

Displacement has long-term consequences for individuals and their families. Future research should explore longitudinal how IDPs integrate into their host communities. Examining inter-generational understandings of displacement will show if IDP populations have resettled successfully. One avenue for future research could productively focus on people who were children and young adults when they resettled in urban areas. Factors such as social and economic standing may influence the success or failure of long-term integration into urban centers. In addition, analyzing how laws continue to change, and their effects on collective movements, will yield data on people's agency toward enacting change that benefits them. 
More broadly, future research could also fruitfully examine whether if IDPgroup mobilization attempts to address the root causes of displacement. A significant social disruption since the 1980s, Colombia's internal violence shows no sign of abating. No solution to the plight of people threatened, beaten, fumigated on, recruited into forced warfare, murdered, or displaced will be attained if the government, the non-displaced public, international organizations, and NGOs in Colombia do not address the root causes of the contemporary problem. In Colombia today, laws merely deal with the aftereffects of displacement, rather than treating the root causes of violent displacement itself.

Since the mid-1960s, the Colombian government has fought militarily with guerrillas who seek to dismantle the current political system. Since the late-1970s, paramilitaries have attacked, with impunity, unarmed civilians who have been accused of being guerrilla sympathizers. Since the mid-1980s, over 5 million people have been displaced from their homes, lands, and place of employment due to violence. Violence, and war, is no longer a one time, traumatic event; rather, it has become a reality for generations (Lubkemann 2008). In Colombia, citizens are living through violence and have appropriated the effects of violence, continuing to form culturally specific goals and projects.

Some internally displaced persons decide that it is best to keep quiet. Keeping quiet and not reporting crimes or injustices at times has become a safer action than reporting crimes. Many who become displaced are afraid to tell their story to the police or authorities who might help them because the violent actors who displaced 
them receive support from these same authorities. Javier Francisco, introduced in chapter 2, told me that there was little guarantee of official protection after he denounced a perpetrator of violence. He is twenty-seven years old and was displaced after the paramilitaries came to his town. "The paramilitaries would kill for fun," he stated. He said, "If you see that they killed someone, you don't get involved. They can kill you or your family." Many others interviewed expressed the same sentiments. Due to possible repercussions from the perpetrators of violence, keeping quiet is a safer strategy. Authorities lack credibility and trust (Jimeno 2004:116). People now routinely act as if violence is a part of life. People are certainly affected and moved by violence, but they perceive that public institutions ignore their reports (Jimeno 2004:117). The routinization of silence helps those in power because they are never held accountable for the violence people experience everyday. In addition, routinization of silence helps the state hide the atrocities it perpetrated (Zur 1994). Once individuals believe that threats, guerrilla or paramilitary recruitment of their children, and "desapariciones" 23 (disappearances) are normal, everyday happenings, and that the state ignores or sanctions such events, they cease to report them. The issues that force migration of IDPs from the countryside to the city are ongoing. Internal displacement will continue until root causes of this tragedy are addressed.

Keeping quiet not only creates a feeling of security that the state cannot provide, but it also fosters displaced individuals' idea that violence will not be

\footnotetext{
${ }^{23}$ Like many parts of Latin America, "desapariciones" is the term assigned to the event when people go missing and their location is unknown in Colombia. A "desaparecido" (referring to a person who is disappeared) may never be found, and are often thought to be dead or taken away to fight-however, in the majority of times, the person is murdered soon after they disappear.
} 
experienced again-whether in Bogotá or to their friends and family in the IDPs' place of origin. Perpetrators of violence are not tempted to create retribution when people do not denounce wrongdoings (Scott 1992:64). A lack of security follows displaced people in resettlement areas. Therefore I argue for the importance of addressing the root causes of displacement, in addition to focusing on what happens to IDPs once they get to the city, as I have done in this research project. When armed actors responsible for violent displacement are held accountable for their actions, IDPs will be able to denounce atrocities through government institutions, and rural citizens will not be forced to migrate from their homes, lands, places of employment due to uncertainties in their well being.

The government identifies and administers to crises-such as counterinsurgency and illicit drugs - to benefit its political and financial goals through foreign aid. In rural areas, the state seeks to eradicate coca plantations and foster a neoliberal environment so that Colombia may receive international funds tied to development and join the global market (Coca Mama 2001). However, officials hesitate to help displaced people migrating to major cities because it would be an admission of the effects of neoliberal development strategies. The resistance movements, most notably the guerrilla's war against the government, contributes to the suffering of ordinary citizens and causes displacement. In addition, there have been no direct resettlement (to place of origin) policies administered by the Colombian government. Resettlement of IDPs through UAOs occurred only when significant voice and resistance—such as 
the takeover of the Bosa-Kennedy UAO office-happened, and UAO offices are forced to take action.

This thesis has discussed the violence that IDPs have faced and continue to face throughout rural and urban areas of Colombia. Despite NGOs and government institutions-like the Constitutional Court—drawing attention to the hardships, realities, and "unconstitutional state of affairs" that IDPs face everyday, positive changes have only slowly come to fruition over the last ten years. State offices and officials continue to deny people the basic rights that the Colombian Constitution, Law 387, and international humanitarian law (IHL) guarantee. Additionally, the changing legislation affects displaced people only after they have experienced traumatic events of murder and torture of their family and friends, fled their homes with nothing, and resettled in marginalized settings. This legislation, though progressive, fails to address the root causes of displacement. 


\section{References}

Advocacy and U.S. Foreign Policy

2005 U.S. Foreign Policy in Colombia through 1999. http://gustavus.edu/ academics/peacestudies/courses/pcs211/Policy.php, accessed February 7, 2010.

Afflitto, Frank M.

2000 The Homogenizing Effects of State-Sponsored Terrorism: The Case of Guatemala. In Death Squad: The Anthropology of State Terror. Jeffrey A. Sluka, ed. Pp. 114-126. Philadelphia: University of Pennsylvania Press.

Agamben, Giorgio

2005[2003] State of Exception. Kevin Attell, tran. Chicago: The University of Chicago Pres.

Ahearn, Laura M.

2000 Agency. Journal of Linguistic Anthropology 9(1-2):12-15.

Ahumada Beltrán, Consuelo, Álvaro Moreno Duran, and Javier Sánchez Segura 2004 El Desplazamiento Forzado de Colombianos Hacia Ecuador en el contexto del Plan Colombia. Bogotá: CEJA.

Avilés, William

2006a Global Capitalism, Democracy, and Civil-Military Relations in Colombia. Albany: State University of New York Press.

2006b Paramilitarism and Colombia's Low-Intensity Democracy. Journal of Latin American Studies 38(2):379-408.

Bagley, Bruce Michael

2005 Drug Trafficking, Political Violence, and U.S. Policy in Colombia under the Clinton Administration. In Elusive Peace: International, National, and Local Dimensions of Conflict in Colombia. Cristina Rojas and Judy Meltzer, eds. Pp. 21-52. New York: Palgrave Macmillan.

Bello A., Martha Nubia

2006 El desplazamiento forzado en Colombia: acumulación de capital y exclusión social. In Colombia: migraciones, transnacionalismo y desplazamiento. Gerardo Ardila, ed. Pp. 381-395. Bogotá: Unibiblos. 
Bernard, H. Russell

2006 Research Methods in Anthropology: Qualitative and Quantitative Approaches, fourth edition. New York: Altamira Press.

Biolsi, Thomas

2007 Race Technologies. In A Companion to the Anthropology of Politics. David Nugent and Joan Vincent, eds. Pp. 400-407. Oxford: Blackwell Publishing.

Black, Janice Knippers

1999 Inequity in the Global Village: Recycled Rhetoric and Disposable People. West Hartford: Kumarian Press.

Borda Carulla, Susana

2007 Resocialization of "Desplazados" in Small Pentecostal Congregations in Bogotá, Colombia. Refugee Survey Quarterly 26(2):36-46.

Bourdieu, Pierre

1994 Structures, Habitus, Power: Basis for a Theory of Symbolic Power. In Culture/ Power/ History: A Reader in Contemporary Social Theory. Nicholas B. Dirks, Geoff Eley, and Sherry B. Ortner, eds. Pp. 155-199. Princeton: Princeton University Press.

Brubaker, Rogers and Frederick Cooper 2000 Beyond "identity." Theory and Society 29:1-47.

Castillejo Cuéllar, Alejandro

2007 La Globalización del Testimonio: Historia, Silencio Endémico y los Usos de la Palabra. Antípoda: Revista de Antropología y Arqueología 4:76-99.

Cepeda-Espinosa, Manuel José

2008 The Judicial Protection of IDPs in Colombia: The importance of the Guiding Principles. http://www.internaldisplacement.org/8025708 F004CE90B/(httpDocuments)/D51B8A5B881A955CC12575B500 4530CE/\$file/GP10 speech Manuel+Jose+Cepeda-Espinosa.pdf, accessed October 5, 2009.

Central Intelligence Agency

2009 The World Factbook: Colombia. https://www.cia.gov/library/ publications/the-world-factbook/geos/co.html, accessed November 15, 2009. 
Clark, Amy

2007 Chiquita Fined \$25M for Terror Ties. AP, March 15.

CODHES

2010 Codhes Informa: Boletín informativo de la Consultoría para los

Derechos Humanos y el Desplazamiento. http://www.codhes.org/ index.php?option=com_docman \&task $=$ cat_view $\&$ gid $=62 \&$ Itemid $=50$, accessed April 4, 2010.

Cortes S., Celia del Pilar and Ligia Castro de Amaya

2005 Escuela y Desplazamiento Forzado: localidad de Usme integración a la escuela de niños y niñas en condición de desplazamiento. Bogotá: Ultra Office.

Engel, Stefanie and Ana María Ibáñez

2007 Displacement Due to Violence in Colombia: A Household-Level Analysis. Economic Development and Cultural Change 55(2): 335365 .

Erret, Andrés, Clive McAlpine, Kerrie Wilson, Stuart Phinn, and Hugh Possingham 2006 Regional Patterns of agricultural land use and deforestation in Colombia. Agriculture, Ecosystems, and Environment 114(2-4):369386.

Escobar, Arturo

1988 Power and Visibility: Development and the Invention and Management of the Third World. Cultural Anthropology 3(4):428-443. 2007[2004] Identity. In A Companion to the Anthropology of Politics.

David Nugent and Joan Vincent, eds. Pp. 248-266.

Farmer, Paul

2004 An Anthropology of Structural Violence. Current Anthropology 45(3):305-325.

Feldman, Allen

1991 Formations of Violence: The Narrative of the Body and Political Terror in Northern Ireland. Chicago: The University of Chicago Press.

Franco, Saúl

1999 El Quinto: No Matar. Bogotá: Tercer Mundo Editores. 
Frank, Andre Gunder

1970 The Development of Underdevelopment. In Imperialism and Underdevelopment, A Reader. R.I. Rhodes, ed. Pp. 4-17. New York: Monthly Review Press.

Garay, Luis Jorge

2009 Superar la exclusión de la Población Desplazada. Paper presented at the CODHES Conference on Displacement, Bogotá, April 23.

Gibbs, Terry and Garry Leech

2009 The Failure of Global Capitalism: From Cape Breton to Colombia and Beyond. Sydney: Cape Breton University Press.

Gledhill, John

2007 Neoliberalism. In A Companion to the Anthropology of Politics. David Nugent and Joan Vincent, eds. Pp. 332-348. Oxford: Blackwell Publishing.

Gonzáles Bustelo, Mabel

2005 "Desterrados:" Forced Displacement in Colombia. In The

Dispossessed: Chronicles of the Desterrados of Colombia. Alfredo

Molano. Chicago: Haymarket Books.

Gow, David D.

2008 Countering Development: Indigenous Modernity and the Moral Imagination. Durham: Duke University Press.

Gruner, Sheila

2007 Contested Territories: Development, Displacement, and Social Movement in Colombia. In Development's Displacements: Ecologies, Economies, and Cultures at Risk. Peter Vandergeest, Pablo Idahosa, and Pablo S. Bose, eds. Pages 155-186. Vancouver: UBC Press.

Hale, Charles R.

1997 Cultural Politics of Identity in Latin America. Annual Review of Anthropology 26:567-590.

Hall, Stuart

1992 The Questions of Cultural Identity. In Modernity and Its Futures. Stuart Hall, David Held, and Tony McGrew, eds. Pp.273-325. Cambridge: The Open University. 
Henderson, James D.

2001 Modernization in Colombia: The Laureano Gómez Years, 1889-1965. Gainesville: University of Florida Press.

Human Rights Watch

2003 You'll Learn Not to Cry: Child Combatants in Colombia. New York: Human Rights Watch.

Ibañes, Ana Maria and Pablo Querubín

2004 Acceso a tierras y desplazamiento forzoso en Colombia. Bogotá:

Centro de Estudios sobre Desarrollo Económico Facultad de Economía Universidad de los Andes (CEDE).

Internal Displacement Monitoring Centre

2010 Colombia: New displacement continues, response still ineffective. http://www.internal-displacement.org/8025708F004CE90B/\%28http Countries\%29/CB6FF99A94F70AED802570A7004CEC41?

OpenDocument\&expand $=2 \&$ link $=11.2 \&$ count $=10000 \# 11.2$, accessed on May 18, 2010.

Izquierdo, Germán

2005 Del Cartucho al Parque Tercer Milenio. Ciudad Viva.

http://www.ciudadviva.gov.co/septiembre05/periodico/4/, accessed May 18, 2010.

Jimeno, Myriam

2004 Reprimand and Respect, Love and Fear, in Experiences of Violence in Colombia. In Cultural Shaping of Violence: Victimization, Escalation, Response. Myrdene Anderson, ed. Pp. 110-118. West Lafayette: Purdue University Press.

Kline, Harvey F.

2007 Chronicle of a Failure Foretold: The Peace Process of Colombian President Andrés Pastrana. Tuscaloosa: University of Alabama Press.

Leal Buitrago, Francisco

1995 El Estado Colombiano: ¿Crisis de Modernización o Modernización Incompleta? In Colombia Hoy: Perspectivas hacia el siglo XXI. Jorge Orlando Melo, ed. Bogotá: Tercer Mundo Editores. 
Lubkemann, Stephen C.

2008 Culture in Chaos: An Anthropology of Social Condition in War. Chicago: University of Chicago Press.

Lutz, Catherine

2007 Militarization. In A Companion to the Anthropology of Politics.

David Nugent and Joan Vincent, eds. Pp. 318-331. Oxford: Blackwell Publishing.

Lynch, Caitrin

2007 Juki Girls, Good Girls: Gender and Cultural Politics in Sri Lanka's

Global Garment Industry. Ithaca: Cornell University Press.

Malkki, Liisa

1992 National Geographic: The Rooting of Peoples and the

Territorialization of National Identity among Scholars and Refugees.

Cultural Anthropology 7(1):24-44.

Marx, Karl

1967 Commodity Fetishism. In Das Kapital: A Critique of Political

Economy. Abridged version. Friedrich Engels, ed. Pp. 50-63. Chicago:

Gateway.

McDermott, Jeremy

2008 Colombia confronts its bloody past. BBC, August 2.

Medina Gallego, Carlos and Mireya Téllez Ardila

1994 La Violencia Parainstitucional, Paramilitary, y Parapolicial en Colombia. Bogotá: Rodriguez Quito Editores.

Meertens, Donny

2006 Género, desplazamiento forzado y migración. Un ejercicio comparativo en movilidad y proyectos de vid. In Migraciones, transnacionalismo y desplazamiento. Gerardo Ardila, ed. Pp. 427-443. Bogotá: CES, Facultad de Ciencias Humanas, Universidad Nacional, Bogotá.

Meltzer, Judy and Cristina Rojas

2005 Elusive Peace: International, National, and Local Dimensions of Conflict in Colombia. In Elusive Peace: International, National, and Local Dimensions of Conflict in Colombia. Cristina Rojas and Judy Meltzer, eds. Pp. 1-18. New York: Palgrave Macmillan. 
Ministerio de Educación Nacional, Republica de Colombia

2010 Mestizaje en Colombia. http://www.colombiaaprende.edu.co/

html/home/1592/article-88867.html, accessed February 13, 2010.

Ortner, Sherry B.

2006 Anthropology and Social Theory: Culture, Power, and the Acting

Subject. Durham: Duke University Press.

Palacios, Marco

2006 Between Legitimacy and Violence: A History of Colombia, 1875-2002.

Richard Stoller, trans. Durham: Duke University Press.

Parques Nacionales Naturales de Colombia

2009 Preguntas Frecuentes. http://www.parquesnacionales.gov.co/PNN/ portel/libreria/php/decide.php?patron $=01.060301$, accessed November 22, 2009.

Pearce, Jenny

1990 Colombia: Inside a Labyrinth. London: Latin America Bureau Limited.

Peteet, Julie M.

1995 Transforming Trust: Dispossession and Empowerment among Palestinian Refugees. In Mistrusting Refugees. E. Valentine Daniel and John Chr. Knudsen, eds. Pp. 168-186. Berkeley: University of California Press.

Prensa PCC

2009 Desplazados marcharán en Bogotá el 17 de Julio. Prensa PCC, July 10, 2009.

Proyecto Misión Bogotá

2001 De mi tierra vengo: orientaciones para la población en situación de desplazamiento en Bogotá. Bogotá: Alcaldia.

Rojas, Cristina

2005 Elusive Peace, Elusive Violence: Identity and Conflict in Colombia. In Elusive Peace: International, National, and Local Dimensions of Conflict in Colombia. Cristina Rojas and Judy Meltzer, eds. Pp. 209237. New York: Palgrave Macmillan. 
Rojas Rodriguez, Jorge E.

2001 Desplazados: Lógicas de Guerra - Incertidumbres de paz. In Desplazamiento Forzado Interno en Colombia: Conflicto, Paz y Desarrollo. CODHES, ed. Pp. 27-46. Bogotá: Editorial Kimpress Ltda.

Roldán, Mary

2002 Blood and Fire: La Violencia in Antioquia, Colombia, 1946-1953. Durham: Duke University Press.

Rose, Nikolas

1999 Governing. In Powers of Freedom: Reframing Political Thought. Pp. 15-60. Cambridge: Cambridge University Press.

Salcedo, Andrés

2005 Memoria y reconstrucción: desplazamiento forzoso hacia la ciudad de Bogotá de poblaciones campesinas, afrocolombianas e indígenas. In $\mathrm{El}$ Desplazamiento en Colombia. Regiones, ciudades y políticas públicas. Martha Nubia Bello and Marta Inés Villa Comp, eds. Pp. 163-193. Medellín: Corporación Región, Redif, ACNUR, Universidad Nacional de Colombia.

Sánchez, Gonzalo and Donny Meertens

2001 Bandits, Peasants, and Politics. Alan Hynds, trans. Austin: University of Texas Press.

Schaeffer, Robert K.

2003 Debt and Taxes in the Third World. In Understanding Globalization: The Social Consequences of Political, Economic, and Environmental Change. Lanham: Rowman \& Littlefield Publishers, Inc.

Schröeder, Ingo W. and Bettina E. Schmidt

2001 Introduction. In Anthropology of Violence and Conflict. Ingo W. Schröeder and Bettina E. Schmidt, eds. Pp. 1-24. London: Routledge.

Scott, James C.

1992 Domination, Acting, and Fantasy. In The Paths to Domination, Resistance, and Terror. Carolyn Nordstrom and JoAnn Martin, eds. Pp. 55-84. Berkeley: University of California Press. 
Segura Escobar, Nora

2000 Colombia: A New Century, and Old War, and More Internal

Displacement. International Journal of Politics, Culture, and Society 14(1):107-127.

Sewell, William H. Jr.

1992 A Theory of Structure: Duality, Agency, and Transformations. The American Journal of Sociology 98(1):1-29.

2005 Logics of History: Social Theory and Social Transformation. Chicago: University of Chicago Press.

Smith, Dan

2003 The Atlas of War and Peace. London: Earthscan Publications.

Stokes, Doug

2005 America's Other War: Terrorizing Colombia. New York: Zed Books.

Thielen, Jan, dir.

2001 Coca Mama: The War on Drugs. 52 min. Filmmakers Library. New York

Thoumi, Francisco E.

2002 El imperio de la droga: Narcotráfico, economía y sociedad en Los Andes. Bogotá: Editorial Planeta Colombiana, S.A.

UNCHR

20092008 Global Trends: Refugees, Asylum-seekers, Returnees, Internally Displaced and Stateless Persons. http://www.unhcr.org/4a375c426 .html, accessed on April 12, 2010.

Uribe Vélez, Álvaro

2003 Carta del Presidente de la República. In Política de Defensa y Seguridad Democrática. Presidencia de la República y Ministerio de Defensa Nacional. Pp. 5-7. Bogotá: Presidencia de la República y Ministerio de Defensa Nacional.

Vargas Meza, Ricardo

2001 Cultivos Ilícitos, Políticas Antidrogas y Proceso de Paz en Colombia. In Desplazamiento forzado interno en Colombia: conflicto, paz y desarrollo. ACNUR and CODHES, eds. Pp. 61-78. Bogotá: Editorial Kimpress Ltda. 
Webber, Jeffrey R.

2008 Review of The People Behind Colombian Coal: Mining,

Multinationals, and Human Rights. Upside Down World. March 28.

Zur, Judith

1994 The psychological impact of impunity. Anthropology Today 10(3):1217. 


\section{$\underline{\text { Appendices }}$}

Appendix A-Bogotá's Strata by Monthly Wages

\section{Strata of Bogotá Average Monthly Wage}

Stratum 1 (Low-Low) $\quad$ Less than 515,000 Colombian Pesos (Less than 269.00 US Dollars)

\begin{tabular}{|l|l|l|l|}
\hline Stratum 2 (Low) & Between 515,000-1,545,000 Colombian Pesos (269.00-807.00 US Dollars)
\end{tabular}

Stratum 3 (Middle-Low) $\quad$ Between 1,545,000-2,575,000 Colombian Pesos (807.00-1,345.00 US Dollars)

\begin{tabular}{|l|l|}
\hline Stratum 4 (Middle) & Between 2,575,000-4,120,000 Colombian Pesos (1,345.00-2,152.00 US Dollars) \\
\hline
\end{tabular}

\begin{tabular}{|l|l|}
\hline Stratum 5 (Middle-High) & Between 4,120,000-8,240,000 Colombian Pesos (2,152.00-4,304.00 US Dollars) \\
\hline
\end{tabular}

\begin{tabular}{l|l} 
Stratum6 (High) & More than 8,240,000 Colombian Pesos (More than 4,304.00 US Dollars) \\
\hline
\end{tabular} 


\section{Appendix B-Bogotá's Strata through Geographical Distribution}

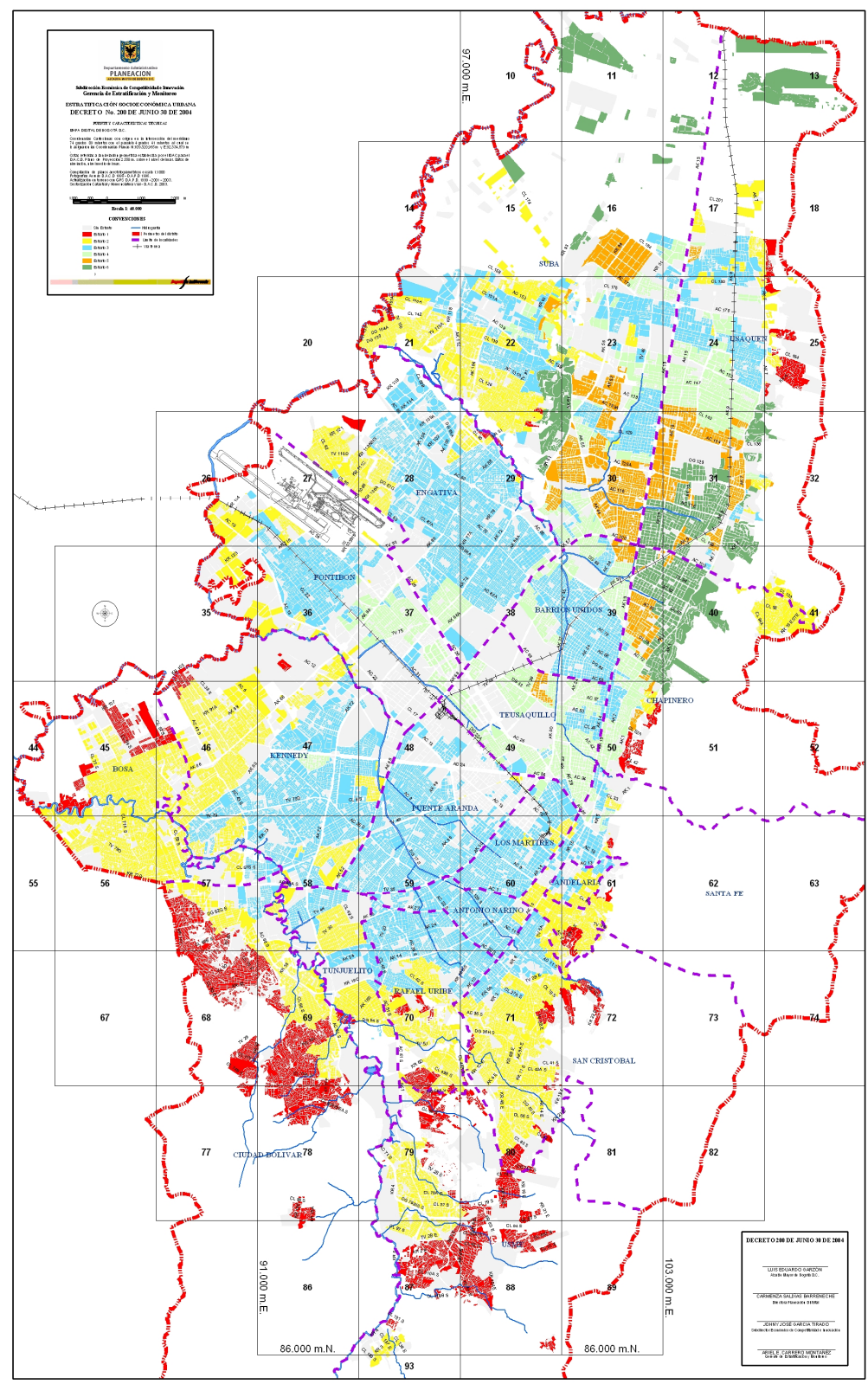

Map of Bogotá (Strata 1Red; Strata 2 Yellow; Strata 3Blue; Strata 4 Light Green; Strata 5 Orange; Strata 6 Dark Green). (Source: http://contenido.metrocuadrado.com/contenidom2/ciudyprec m2/ inforbog_m2/informacingeneral bogot/IMAGEN-WEB-PL_DET_IMAGEN_M2-2026927.html) 


\section{Appendix C-Questions Asked During Interviews}

These are questions I asked IDPs in both the UAO office in Bogotá and the neighborhood in Medellin. These were general topics of conversation. I had follow up questions on the topics discussed, and thus the context for each interview varied.

1) Where are you from?

2) When did you arrive to the city?

3) What part of the city do you live in? How long have you lived three?

4) What has been your experience living in the city? How have you been able to make a living for you and your family?

5) How were you displaced?

6) Why did you decide to move to the city?

7) How do you feel you are treated in the city? What have been some of the reactions from the public?

8) How have your experiences been interacting with the UAO and its workers?

9) How has your family been treated in this city and in the UAO?

10) Why did you come to apply for aid at the UAO?

11) (In Medellín) What have been your experiences living in this neighborhood?

Interview questions for government workers:

1) Where are you from?

2) What is your job?

3) What part of the city do you live in?

4) What has been your experience living in the city? How have you been able to make a living for you and your family?

5) How do you define displaced? 
6) Do you believe that the UAO is helping the displaced in any way?

7) How do you feel the city in general treats the displaced?

8) What have been your experiences interacting with IDPs here in the office?

9) Do you agree with the current policy toward the displaced? If not, how would you change it?

10) Do you think the situation has changed in the past 5 or 10 years in regards to IDPs? How?

11) Why did you start working at the UAO?

Interview questions for non-displaced public:

1) Where are you from originally?

2) Do you believe that displacement is an issue of concern in Colombia?

3) Why do you think people become displaced?

4) How would you describe a displaced person?

5) Why do you believe that many displaced individuals migrate to urban centers in Colombia?

6) Do you believe that the displaced population is mistreated here in Colombia?

7) What are your personal thoughts on the displaced population?

8) Do you know any ways in which the displaced population receives aid, either by the government or other organizations? If you do, do you agree with those policies?

9) Should the situation be changed? If so, how do you think displacement in Colombia can be ameliorated?

10) Do you interact with the displaced population? Do you know any displaced person? 


\section{Appendix D-Letter IDPs Receive After Declaration}

Letter written by the Personería and Procuraduría after a declaration (in Spanish):

El (la) señor (señora) .......... identificado(a) con la cedula de ciudadanía ........... de (ciudad), rindió declaración juramentada de desplazamiento y se encuentra en trámite la respectiva evaluación e inscripción en el Registro Único Nacional de Personas Desplazadas por la violencia, certificado que será expedida por Acción Social.

(List of Family)

El presente documento tiene validez para acceder a los servicios de salud incluyendo las acciones de promoción y prevención, atención de urgencias y acciones contenidas en el Plan Obligatorio de Salud (POS), de conformidad con la circular No. 006 de marzo del 2006 de la Secretarial Distrital de salud.

(In English):

Mr. (Mrs.) ........ identified with Citizenship Card \# ........ of (city's name of origin), has provided a declaration under oath of displacement, which has been sent for an evaluation and registration to the National Register of Displaced Persons due to violence. This declaration has been certified that it will be expedited by Acción Social. 
(List of family members)

This document upholds the right to seek medical services, including preventative care, emergency care, and all types of care included in the Obligatory Health Plan (POS) written on writ No. 006 of March 2006 of Health Secretary of the District. 